\title{
REASONS FOR THE LOW RATE OF CONVICTION IN THE VAW CASES AND INCONSISTENCIES IN THE LEGISLATIVE FRAMEWORK
}

S.M. ATIA NAZNIN AND TANJINA SHARMIN

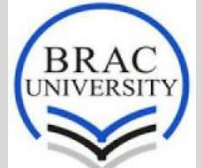

BRAC UNIVERSITY PRESS 2015

A REVISED VERSION PUBLISHED ON 8 JUNE, 2015 
A PUBLICATION ONLY FOR COMPLIMENTARY DISSEMINATION AND NOT FOR SALE

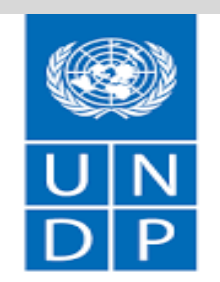

Empowered lives.

Resilient nations.

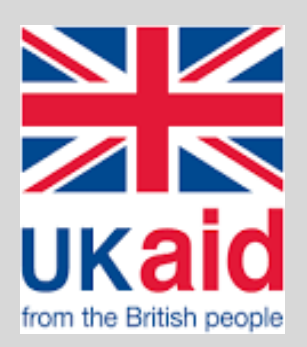

BRAC

UNIVERSITY 


\section{REASONS FOR THE LOW RATE OF CONVICTION IN THE VAW CASES AND INCONSISTENCIES IN THE LEGISLATIVE FRAMEWORK}

S.M. ATIA NAZNIN AND TANJINA SHARMIN

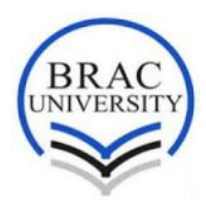

BRAC UNIVERSITY PRESS 2015

A REVISED VERSION PUBLISHED ON 8 JUNE, 2015 
A Report of the VAW Research Project Implemented by the School of Law, BRAC University Bangladesh on the basis of a Memorandum of Understanding with the Justice Sector Facility Project (JSF) Undertaken by the Ministry of Law, Justice and Parliamentary Affairs of Government of the People's Republic of Bangladesh and Funded by the United Nations Development Programme (UNDP) Bangladesh

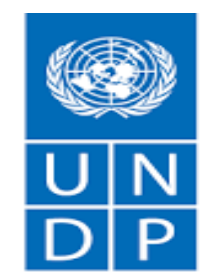

Empowered lives.

Resilient nations.

Also supported by

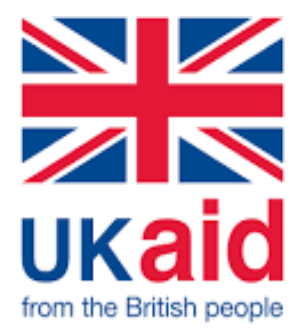

A PUBLICATION ONLY FOR COMPLIMENTARY DISSEMINATION AND NOT FOR SALE

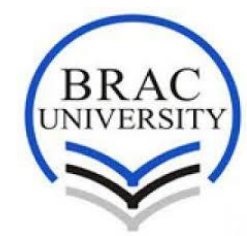

DHAKA, BANGLADESH

FIRST PUBLISHED ON 27 MAY, 2015

THIS IS THE REVISED VERSION PUBLISHED ON 8 JUNE, 2015 


\section{DISCLAIMER}

The work publishes the research findings following Quantitative and Qualitative research methodologies. The conclusion drawn by the authors on the basis of the collected data and comparisons among different legislative provisions does not constitute any former legal or other professional advice. BRAC University shall not assume any liability for action taken on the basis of information, findings or opinions in this work.

\section{Copyright $@$ reserved by BRAC University, Dhaka, Bangladesh}

All rights relating to this work are reserved. No part of this publication may be reproduced, stored in a retrieval system or transmitted in any form by any means without prior written permission of BRAC University.

\section{A Peer Reviewed Publication Reviewed by a Total Number of Five Experts}

The Reviewers' panel was constituted by the Justice Sector Facility (JSF) Project funded by the UNDP, Bangladesh from the regular Consultants working with the UNDP on the related issues

\section{May be cited as}

S.M. Atia Naznin and Tanjina Sharmin, The Research Report of the VAW Project, BRAC University, "Reasons for the Low Rate of Conviction in the VAW Cases and Inconsistencies in the Legislative Frameworks", BRAC University Press, 2015

First Published on 27 May, 2015

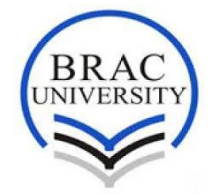

BRAC University 66 Mohakhali, Dhaka-1212, Bangladesh 


\title{
REASONS FOR THE LOW RATE OF CONVICTION IN THE VAW CASES AND INCONSISTENCIES IN THE LEGISLATIVE FRAMEWORK
}

\author{
S.M. Atia Naznin* \\ Research Fellow of the VAW Project \\ And \\ Tanjina Sharmin* \\ Focal Person and Research Fellow of the VAW Project
}

\footnotetext{
${ }^{*}$ S. M. Atia Naznin is a Lecturer at the School of Law, BRAC University, Bangladesh. She is also an enrolled advocate of Bangladesh Bar Council. Ms. Naznin completed her second Masters in Human Rights and Democratization from the University of Sydney, Australia under the Human Rights and Democratization Scholarship of the European Union and the University of Sydney. Prior to that, she did Master of Laws (LL.M.) and Bachelor of Laws (LL.B.) from the Department of Law, University of Dhaka, Bangladesh. For any comment on this research, please feel free to contact Ms. Naznin at: atianaznin@bracu.ac.bd.

${ }^{*}$ Ms. Tanjina Sharmin is an Advocate of the Supreme Court of Bangladesh. She is also working as a Lecturer of Law at the School of Law, BRAC University Bangladesh. Tanjina has completed her Master of Law (LL.M.) from the University of Cambridge, UK specializing in Commercial and International Laws. She is a former Commonwealth Scholar. Ms. Sharmin completed another Master of Law (LL.M.) and her Bachelor of Laws (LL.B. Hons) from the University of Dhaka, Bangladesh. For any comment relating to this work, Ms. Sharmin may be contacted at: tanjina.sharmin@cantab.net or at: tanjina@bracu.ac.bd.
} 


\section{ACKNOWLEDGEMENT}

The VAW research team gratefully acknowledges the help of Dr. Shahdeen Malik, the Director of the Law School, BRAC University for his academic scrutiny and administrative support. We remain thankful to the Justice Sector Facility (JSF) Project funded by the United Nations Development Program (UNDP) Bangladesh for supporting this Project. We are grateful to the BRAC University Administration for facilitating the implementation of our work.

We acknowledge the work of the VAW Project Research Assistants, Mr. S.M. Hasib Mahmud and Mr. Amit Sarkar. They helped us to collect and organize data and to prepare the case studies. S.M. Hasib Mahmood summarized some judgments and has prepared the list of Acronyms and Bibliography. Mr. Amit Sarkar helped us in administrative works. We also acknowledge the work of Mr. Farooq Faisal, our Statistical Analyst who helped us to design the quantitative research strategy and data analysis.

The VAW research team is especially grateful to the Nari-o-Shishu Nirjatan Daman Tribunals

and Magistrate Courts of Dhaka, Comilla and Pabna for helping us with required data and statistics of the VAW Cases. We are thankful to the Judges, Public Prosecutors, Lawyers, Court Clerks and all other participants of qualitative and quantitative interviews taken for this work. 


\section{TABLE OF CONTENTS}

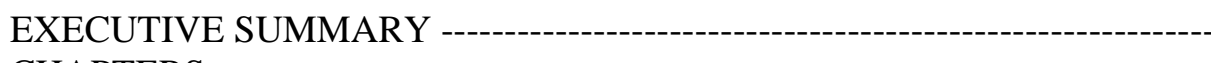

CHAPTERS

CHAPTER - 1: INTRODUCTION

1.1 Background and justification

$11-12$

1.2 Scope of the study

1.3 Objective and expected results

1.4 Limitations
13

$14-15$

15

16-18

18

18-19

19

20

20-21

21-25

25-27

28-29

29-30

30-32

$32-36$

$37-42$

43

43-58

$58-69$

69-71

\section{CHAPTER - 6: DATA ANALYSIS AND FINDINGS ON LEGISLATIVE INCONSISTENCIES IN THE VAW LEGISLATIONS}

6.1 Section-1: Summary of quantitative and qualitative data on the VAW legislative inconsistencies collected from

Dhaka, Comilla and Pabna Courts

6.2. Section-2: Comparison of the relevant provisions of the selected VAW legislations 


\section{LIST OF ACRONYMS}

ACDJ

$\mathrm{AD}$

APP

CEDAW

CJM

CMM

CPC

CR

CrPC

DL

DPA

DSJ

$\mathrm{DV}(\mathrm{PP}) \mathrm{A}$

FCO

GR

HCD

JSF

MFLO

NOSNDTC

NOSNDTD

NOSNDTP

NWDP

PP

PRBAC

PRBAP

SP(NOSNDT)

UNDP

VAW

Acting District Judge

Appellate Division

Assistant Public Prosecutor

Convention on the Elimination of All Forms of Discrimination against

Women

Chief Judicial Magistrate

Chief Metropolitan Magistrate

Code of Civil Procedure

Complaint Registrar

Code of Criminal Procedure

Defence Lawyer

Dowry Prohibition Act, 1980

District \& Sessions Judge

Domestic Violence (Prevention and Protection) Act, 2012

Family Courts Ordinance, 1985

General Registrar

High Court Division

Justice Sector Facility

Muslim Family Laws Ordinance, 1961

Nari-o-Shishu Nirjatan Daman Tribunal Comilla

Nari-o-Shishu Nirjatan Daman Tribunal Dhaka

Nari-o-Shishu Nirjatan Daman Tribunal Pabna

National Women Development Policy

Public Prosecutor

President of Bar Association, Comilla

President of Bar Association, Pabna

Special Judge (Nari-o-Shishu Nirjatan Daman Tribunal)

United Nations Development Programme

Violence against Women 


\section{EXECUTIVE SUMMARY}

Violence against women is considered as one of the most pervasive and shameful violations of human rights of the world. In this context, Bangladesh has promulgated several legislations to combat violence against women. Along with the general substantive and procedural criminal legislations in force in Bangladesh, e.g., the Penal Code 1860 and the Code of Criminal Procedure 1898, several special criminal legislations have been enacted time to time to strictly punish the offences against women. Among them, the most prominent special criminal legislation now in force in Bangladesh which deals with the offences concerning violence against women is the Nari-o-Shishu Nirjatan Daman Ain 2000. This Act was enacted in the context of the loopholes in the Nari-o-Shishu Nirjatan Daman (Bishesh Bidhan) Ain 1995 which was in force before the promulgation of the Nari-o-Shishu Nirjatan Daman Ain 2000 except for the cases already filed under the Act of 1995. However, since the enactment of the Act of 2000, it has been facing criticisms for not being able to prevent violence against women effectively. One of the major concerns has been the abysmally low rate of conviction in the cases filed under the provisions of the Nari-o-Shishu Nirjatan Daman Ain 2000. In a report of Bangladesh Law Commission, it is found that the conviction rate in the VAW cases filed under the provisions of the Nari-o-Shishu Nirjatan Daman Ain 2000 is below 10\% on an average. It can, therefore, be inferred that there must be some loopholes in the law because of which it has been failing to address this extreme low rate of conviction in the VAW cases.

Following this context, the current research investigates broadly into two legal issues concerning violence against women (VAW) in Bangladesh. The first investigation relates to the reasons for the low conviction rate in the VAW cases filed under different provisions of the Nari-o-Shishu Nirjatan Daman Ain 2000, a special criminal legislation dealing with the VAW offences. The second investigation, on the other hand, looks into the legislative inconsistencies in the four specific VAW legislations namely, the Nari-o-Shishu Nirjatan Daman Ain 2000, the Dowry Prohibition Act 1980, the Domestic Violence (Prevention and Protection) Act 2010 and the Family Courts Ordinance 1985.

This research has followed the mixed method approach combining both the quantitative and qualitative research methodology. Through quantitative data analysis and qualitative comparison of the legal provisions and judicial decisions, the present work hypothyses lack of proper and adequate evidence, weak presentation of the prosecution case, technicalities of law, harshness of law, filing of false, weak police investigation, out of court settlement, and case backlog as the main reasons responsible for the low conviction rate.

For further investigation, based on the available statistics of cases in 2009 to 2014, Chapter Five then looks into whether the conviction rate is really low in the VAW cases considering the number of conviction in proportion to the number of cases filed and disposed of in the trial courts. Secondly, after establishing the fact of the low rate of conviction in the VAW cases by the relevant statistics, the research verifies these hypotheses analyzing the quantitative and 
qualitative data collected from the justice sector agencies, judgments of the Supreme Court in 2000 to 2013 and the case studies of the trial court to locate the underlying reasons for the low rate of conviction. Chapter Five, in addition, finds that non-application of judicial mind by the trial court is another important reason responsible for the low rate of conviction. Over the years, this is exhibited that convictions in the VAW cases cannot sustain because of the improper application of law, legal infirmity, and lack of sound reasoning in the trial court's decision, excessive use of jurisdiction by the trail court, framing of wrong charge by the Tribunal, and the inappropriate trial procedure. Based on these findings, Chapter Seven puts forward several recommendations to mitigate the current trend of low conviction rate. Lastly, it is clarified that by identifying the level and reasons behind low conviction rate in the VAW cases, this research in any way does not advocate for the conviction rate to be high, rather, it expects a proper administration of justice aiming to uphold the rights of the poor and marginalized victims of violence as envisioned in the Act of 2000.

The part of legislative inconsistencies also initiates with some hypotheses. The initial hypothesis was that there may be inconsistencies in the provisions of the selected the VAW legislations which may affect the administration of justice. Accordingly, data has been collected from the participants of quantitative interview asking them whether they experience any legislative inconsistency in the VAW legislations. Most of the participants answered that there is no glaring inconsistency but there are some problems which should be resolved by legislative amendment.

Later, the above mentioned finding has been cross-verified by a qualitative comparison of the selected VAW legislations. Thus, It is found that, indeed there are some procedural and substantive inconsistencies in the selected VAW legislations. The provisions of dowry related offences in the Nari-o Shishu Nirjatan Daman Ain 2000 and in the Dowry Prohibition Act 1980 should be more consistent. All the dowry related offences should be dealt by one single legislation. Currently, dowry related offences are being dealt in both the Nari-O-Shishu Nirjatan Daman Ain 2000 and the Dowry Prohibition Act 1980. Uniform terminologies should be used to define 'Dowry'. The procedural provisions of the Nari-o Shishu Nirjatan Daman Ain 2000 should be more clarified to avoid any confusion with the provisions of the Code of Criminal Procedure 1898. The provisions in the Nari-o Shishu Nirjatan Daman Ain 2000 relating to bail granting power in the General Registrar (GR) cases are required to be extended. The Nari-O Shishu Nirjatan Daman Tribunals may be given with the power of granting bail at any stage of the proceedings. The provisions relating to the custody of child in the Domestic Violence Act 2010 and in the Family Courts Ordinance 1985 should be consistent and clear mentioning explicitly to which forum one should go in any particular situation. Moreover, the definition of "Child" should be uniform in all the VAW legislations.

The judgment in a recent case, Shukkur Ali vs. State, pronounced by the Appellate Division of Bangladesh Supreme Court on 5 May 2015 has recommended for revising the dowry related provisions in the Nari-o-Shishu Nirjatan Daman Ain 2000. This judgment has also declared the mandatory death sentence for murder after rape provided in the Nari-o-Shishu Nirjatan Daman Bishesh Bidhan Ain 1995 to be unconstitutional. The Appellate Division has annulled section 34 
(2) of the Nari-o-Shishu Nirjatan Daman Ain 2000 by which the already filed cases for murder after rape before coming into operation of the Act of 2000 used to continue to be tried under the Act of 1995. These decisions of the Appellate Division should be incorporated into law by legislative amendment to make the VAW legislations more consistent. 


\section{CHAPTER 1 \\ INTRODUCTION}

\subsection{BACKGROUND AND JUSTIFICAITON}

There are a number of commitments in the Constitution of the People's Republic of Bangladesh to ensure the rights of women equally with men in all spheres of the State and public life. ${ }^{1}$ Therefore, prevention of all forms of violence against women (VAW) is an aim of the State. The State has promulgated several legislations to materialize this aim. Along with the general substantive and procedural criminal legislations in force in Bangladesh, e.g., the Penal Code 1860 and the Code of Criminal Procedure 1898, different special criminal legislations have been enacted time to time to strictly punish the offences against women.

The most prominent special criminal legislation now in force in Bangladesh which deals with the offences concerning violence against women is the Nari-o-Shishu Nirjatan Daman Ain 2000. This Act was enacted in the context of the loopholes in the Nari-o-Shishu Nirjatan Daman (Bishesh Bidhan) Ain 1995 which was in force before the promulgation of the Nari-o-Shishu Nirjatan Daman Ain 2000 except for the cases already filed under the Act of 1995. However, since the enactment of the Nari-o-Shishu Nirjatan Daman Ain 2000 it has been facing criticisms for not being able to prevent violence against women effectively. One of the major concerns has been the abysmally low rate of conviction in the cases filed under the provisions of the Nari-oShishu Nirjatan Daman Ain 2000.

In a report of Bangladesh Law Commission, it is found that the conviction rate in the VAW cases filed under the provisions of the Nari-o-Shishu Nirjatan Daman Ain 2000 is below 10\% on an average. ${ }^{2}$ It can be inferred that there must be some loopholes in the law because of which the law is failing to address this extreme low rate of conviction in the VAW cases. The reasons for the low conviction rate in the VAW cases may include harshness and excessive technicalities of $\mathrm{law}^{3}$, filing of false cases, framing of charge under inappropriate sections of law, inconsistencies of Nari-o-Shishu Nirjatan Daman Ain 2000 with the general criminal legislations, lack of evidence, lack of legal assistance, lack of preparation in prosecution case and lack of witness.

Whatever the reasons may be, the noticeable rate of low conviction in the VAW cases may be construed as a signal that this special criminal legislation is failing firstly, to ensure access to justice for women and secondly, to prevent the misuse of its own provisions. Besides, the

\footnotetext{
${ }^{1}$ The Constitution of the People's Republic of Bangladesh Article 28.

2 The Law Commission of Bangladesh: A Report on the Amendment of Certain Sections of the Nari-o-Sishu Nirjatan Daman Ain 2000 (25/08/2010) <http://www.lawcommissionbangladesh.org/reports/99.pdf>.

3 Dr. Shahdeen Malik, 'Nari-o-Shishu Ain and Special Tribunals: Looking at Law and its Implementation' (Unpublished Draft Report prepared for Naripokkho (2004) 3.
} 
excessive rate of non-conviction implies a loss of substantial resources of the State and society. ${ }^{4}$ In this context, this present research takes up this issue for further investigation. In doing so, this work will at first look into whether the conviction rate is really low in the VAW cases considering the rate of filing, disposal and conviction rate of the VAW cases in different Nari-oShishu Nirjatan Daman Tribunals constituted under the Act of 2000. Secondly, if the low conviction rate is established by the relevant statistics, the research will investigate into the underlying reasons for the low rate.

Apart from an investigation on low conviction rate in the VAW cases, this research will also examine the issue of legislative inconsistencies in the four specific VAW legislations namely, the Nari-o-Shishu Nirjatan Daman Ain 2000, the Dowry Prohibition Act 1980, the Domestic Violence (Prevention and Protection) Act 2010 and the Family Courts Ordinance 1985. Examination of legislative inconsistencies in the VAW legislations is significant because the ideal VAW legislations are expected to be specific and consistent. ${ }^{5}$ Any inconsistency in the form of contradiction or overlapping in the VAW legislations may ultimately affect access to justice for women and effective delivery of justice.

A research on legislative inconsistencies and the reasons for the low conviction rate in the VAW cases will find out inconsistent legal provisions and other loopholes in the VAW legislations. The findings of this present research, therefore, will ultimately help to strengthen the administration of justice in the VAW cases and ensure access to justice for the marginalized women in Bangladesh and to develop a better coordination among the justice sector agencies. One of the aspects of establishing rule of law in a country is to make the justice accessible for all, especially for those who represent the marginalized section of the society, for example, women. Mere recognition of legal rights cannot effectively ensure women's rights unless there is an effective justice delivery system to make those rights accessible to them. ${ }^{6}$ The present research therefore, will facilitate the justice sector, particularly, in the issues concerning violence against women.

Lastly, the present work is supportive to the key objectives of the Justice Sector Facility Project (JSF) funded by the United Nations Development Program (UNDP), Bangladesh. One of the JSF's key objectives is to enhance communication, coordination and cooperation among the justice sector agencies with a view to strengthening the institutional planning capacities in the administration of criminal justice system with the ultimate objective to protect rights of all citizens, particularly, of the women, children and other vulnerable groups. ${ }^{7}$ The same are the objective and goal of the present work.

\footnotetext{
${ }^{4}$ Ibid.

${ }^{5}$ United Nations Handbook, Good Practices in Legislation on Violence against Women, (2008)

<http://www.un.org/womenwatch/daw/egm/vaw_legislation_2008/expertpapers/EGMGPLVAW_.pdf.>.

6 Jamila Ahmed Chowdhury, 'Legal Aid and Women's Access to Justice in Bangladesh' (2012) 1 International Research Journal of Social Sciences 8.

${ }^{7}$ United Nations Development Programme, Quarterly Progress Report (July-September 2013)

<http://www.undp.org/content/dam/undp/documents/projects/BGD/JSF_Q3_2013_Report.pdf.>
} 


\subsection{SCOPE OF THE STUDY:}

This research is conducted to support the Justice Sector Facility (JSF) Project undertaken by the Ministry of Law, Justice and Parliamentary Affairs of Bangladesh in collaboration with the United Nations Development Program (UNDP) Bangladesh. The aim of the whole project is to facilitate the judiciary to reduce case backlog, ensuring effective access to justice and to promote better administration of justice. Accordingly, this study focuses on two broad aspects of the cases on violence against women, i.e. firstly, reasons for the low conviction rate in the VAW cases and secondly, the legislative inconsistencies in the VAW legislations.

To address the first issue, this work investigates into the reasons for the low conviction rate in the cases filed under the Nari-o-Shishu Nirjatan Daman Ain 2000. The second issue concerns the legislative inconsistencies in the four specific VAW legislations namely, the Dowry Prohibition Act 1980, Nari-o-Shishu Nirjatan Daman Ain 2000, Family Courts Ordinance 1985 and the Domestic Violence (Protection and Prevention) Act 2010. These two broad issues necessarily imply a number of sub-issues having significant implications on the main research issues.

In connection with the first issue, this research aims to address whether the rate of conviction in the VAW cases is truly low or not. If it is found that the conviction rate is low after initial investigation, then the present work will further investigate into the reasons for such low conviction rate. To deal with the second issue, this project aims to figure out whether there is any inconsistency at all in the selected legislations. If any inconsistency is found, the work will identify the related legislative provisions. Findings of both the abovementioned research issues may at the end propose necessary legislative and judicial reforms.

The research questions set above meet two fundamental criteria of being good research questions namely, interest and researchable nature. ${ }^{8}$ The research questions addressed by this work are neither too specific about a specific individual nor even too grand and therefore meet the requirement of having researchable nature. ${ }^{9}$ At the same time, the research questions are socially important encompassing a puzzle and idea (issue and corresponding new twist of investigation)

and thereby are interesting. ${ }^{10}$ Accordingly, the identified research issues within the set scope are capable of bringing out a reliable report to be acted upon by the justice sector agencies and law reformers in the future.

\footnotetext{
${ }^{8}$ Glenn Firebaugh, Seven Rules for Social Research (Princeton University Press, 2008$) 1$.

${ }^{9}$ Ibid.

${ }^{10}$ Glenn, above $\mathrm{n} 8$.
} 


\subsection{OBJECTIVES AND EXPECTED RESULTS}

The specific and concrete results expected to be achieved through the present research are as follows:

- Ensuring accountability among the related justice sector agencies;

- Creating awareness among the justice sector agencies as per their duties under the Nari-O Sishu Nirjatan Daman Ain 2000;

- Enlightening one particular sector from the shared experiences of other justice sector agencies;

- Finding out a holistic, coordinated and national level solution through intensive study on three districts, e.g., Dhaka, Pabna and Comilla.

Based on these objectives, the current research indentifies two sectoral target beneficiaries who will be directly or indirectly benefited from the study outcome, e.g.,

(i) Primary or direct beneficiaries: a) agencies involved in law making and policy formulation, e.g., Ministry of Law, Justice and Parliamentary Affairs, Ministry of Social Welfare, Ministry of Women and Children Affairs and the related parliamentary committees and b) agencies involved in implementing laws and policies, i.e., Judges of the adjudicating Tribunals, public prosecutors, lawyers and police officers, women's rights organisation and the national human rights organisations.

(ii) Ultimate beneficiaries: vulnerable, marginalised and poor women litigants.

As to the quantitative indication of the above identified beneficiaries, the research stipulates that it is difficult to predict the exact number of beneficiaries to be benefited by this work at the initial stage. However, based on the expectations and the implication of the overall study, the present work expects that it will embrace all the justice sector agencies, law reformers and victims of the VAW cases generally.

As the first group of beneficiaries are involved in law and policy formulation or implementation, therefore, the study expects a two-way result. Firstly, the potential solutions to the problem of low conviction rate under the Nari-o-Sishu Nirjatan Daman Ain 2000 will definitely help these particular agencies in combating this challenge more proactively. Besides, the identification of the underlying reasons for the low rate of conviction may help them to come forward with innovative ways of solution in redressing this problem. This may happen by bringing changes in the particular legislation and its proper implementation. The second group of beneficiaries are 
then expected to be comparatively free from harassment or loss of time, resources and energy. At the same time, identifying legislative inconsistencies in the VAW legislations will help the target beneficiaries to ensure and experience better administration of justice and access to justice.

\subsection{LIMITATION}

The present research admits a number of limitations which could not be avoided with a reasonable effort in the course of undertaking the works. The quantitative data and statistics relied on are not comprehensive. The survey and field works were undertaken in Dhaka, Comilla and Pabna only. Due to time and resource constraints, data from all the Nari-o-Shishu Nirjatan Daman Tribunals all over the country could not be brought under investigation. Also, the study of the reported Supreme Court's judgments referred in this work is not comprehensive. The present work did not study all the reported judgments of the Supreme Court available in all the law reports of Bangladesh. Instead, all the cases reported in some of the reputed law reports, e.g., Bangladesh Law Reports (BLC), Bangladesh Legal Decisions (BLD), Bangladesh Law Times (BLT), Dhaka Law Reports (DLR), and Mainstream Law Reports (MLR) from 2000-2013 are analysed. The present research could not study the unreported judgments of the Nari-o-Shishu Nirjatan Daman Tribunals of Dhaka and Pabna due to unavailability. Only six unreported judgments of the Nari-o-Shishu Nirjatan Daman Tribunal of Comilla, however, could be studied by this research as the Comilla Court had kindly made those available for this work. The whole work is undertaken and completed in a six month time. Therefore, all the relevant issues may not have been addressed comprehensively by this research. 


\section{CHAPTER 2 RESEARCH DESIGN AND METHODOLOGY}

\subsection{METHODOLOGY}

This chapter of the study gives a brief overview of the methodology applied for the present research along with the suitability and appropriateness ${ }^{11}$ of such methodology to the current work. The methodology to be applied for this work is selected considering the nature of the research problem and the related issues ${ }^{12}$, the researcher's knowledge developed by relevant literature review and the ultimate purposes of the study. The two broad issues addressed by this study are, investigation into the low conviction rate in the VAW cases filed under the Nari-oSishu Nirjatan Daman Ain 2000 and the legislative inconsistencies in the four specific VAW legislations.

The research on the reasons for the low conviction rate begins with a hypothesis that the conviction rate is low in the VAW cases. This hypothesis is initially adopted on the basis of a literature review. The acceptance or rejection of this hypothesis requires numerical survey for which Quantitative Method of study is found to be the most appropriate. Quantitative Method in this context is understood as explaining phenomena by collecting numerical data that are analyzed using mathematically based methods (particularly statistics). ${ }^{13}$ Upon an initial finding on this hypothesis (if the hypothesis is confirmed), the work will aim to figure out the reasons for such low conviction rate. At this point, the work requires addressing the 'why' questions, side by side of the 'what' questions. To answer the 'why' questions, inductive data analysis and the researcher making interpretations of the meaning of the data are obvious. These processes are the attributes of the Qualitative Method. ${ }^{14}$ Therefore, for this section, Qualitative method will be applied side by side of the Quantitative method.

By contrast, the research on inconsistencies in the selected legislations on the VAW starts with a hypothesis that there may be inconsistencies in these legislations that ultimately lead to case backlog. This hypothesis draws its origin from the VAW Roadmap Conference organized by the

11 Research methods are ideally chosen on the basis of its most appropriateness to the research question. For details, refer to: Md. Zabir Hasan, MBBS, MPH, Research Associate, James P. Grant School of Public Health, BRAC University, 'Steps of Research', slides developed for the Training on Research Method and SPSS by ICDDRB, (Undated Study Material).

12 John W. Cresswell, Research Design: Qualitative, Quantitative, and Mixed Method Approaches (3rd Ed.) (Sage Publications, 2009).

13 A definition of Qualitative Method by Aliaga and Gunderson (2000), referred by Mark Balnaves and Peter Caputi, Introduction to Quantitative Research Method (Sage Publications Limited, 2001).

${ }^{14}$. Ibid. 
JSF Project in 2014. The confirmation or rejection of this again calls for a Quantitative survey. If the finding is positive, the inconsistent provisions of law are required to be found out. Collection of numerical data on the basis of a set questionnaire is found to be the most appropriate strategy for this work. A qualitative study of the provisions of the VAW legislations, however, is to be applied then to verify and confirm the result of the Quantitative survey.

For comprehensiveness, the study, therefore, applies a mixture of both Quantitative and Qualitative research method which is usually known as Mixed Method Approach. ${ }^{15}$ This approach involves a merger of primary and secondary data and is believed to be capable to best serve a transformative purpose to advocate for the marginalized groups, such as women or other minorities. ${ }^{16}$ The following methods are adopted to address the issue of low conviction rate and related bottlenecks:

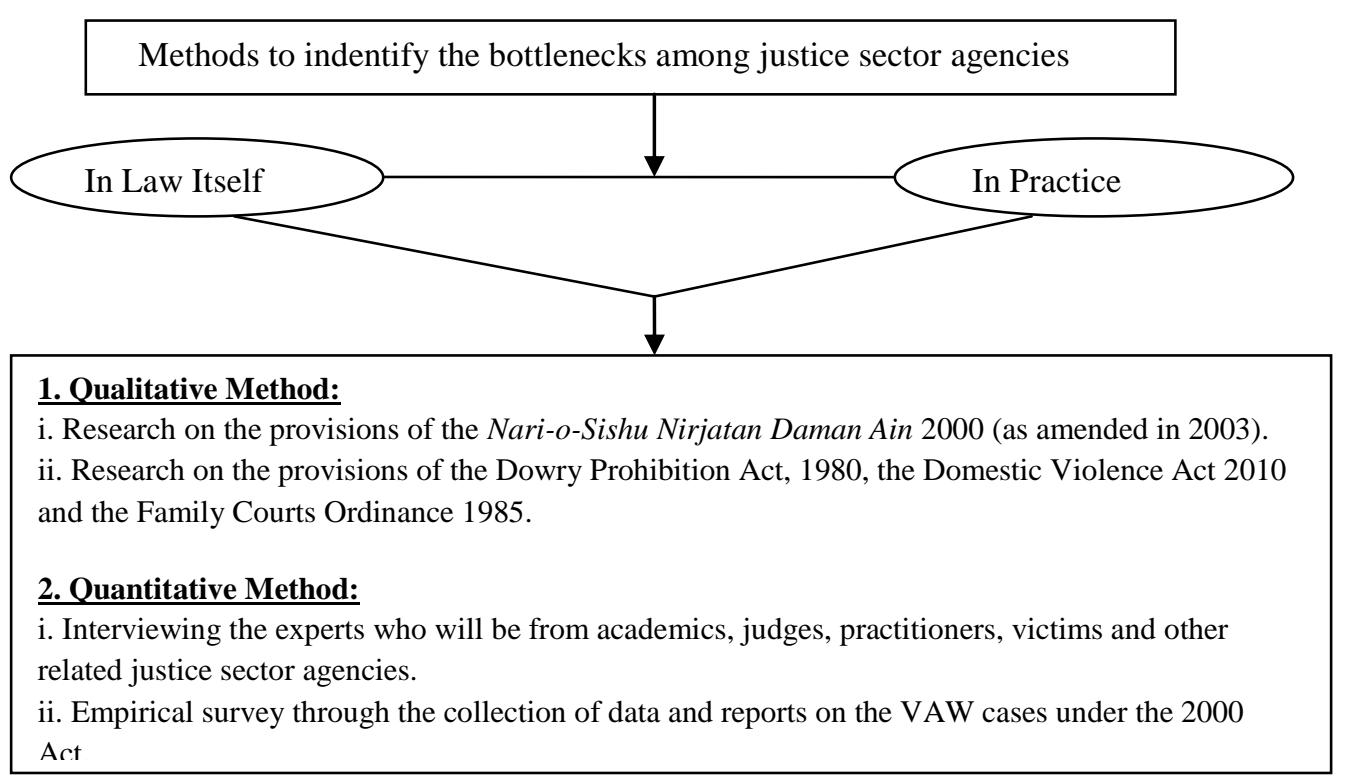

This research believes that any initiative to justice sector reform must address bottlenecks in the entire system in order to motivate people to report incidents and to promote case prosecution. Various studies have identified that the systematic or structural bottlenecks among the justice sector institutions in the VAW cases filed under the Nari-o-Sishu Nirjatan Daman Ain 2000 exists from the pre-trial stage to the implementation of the Tribunal's Judgment. The current research will particularly focus on this issue from the context of low conviction rate in the VAW cases. Specifically, the bottlenecks affect the right to access to justice which has been acting as a major disincentive for the women litigants to come before the court. Therefore, a research on this

\footnotetext{
15 Ibid.

${ }^{16}$ Cresswell, above n 12.
} 
issue while finding out a potential solution to this problem will address all the related bottlenecks to ensure and establish an effective justice delivery mechanism.

\subsection{DATA COLLECTION AND SAMPLING}

Before identifying the participants (representative sample) for the Quantitative interview, the work identifies the target population carefully and precisely ${ }^{17}$. Since the whole undertaking is to facilitate the justice sector, this study considers the justice sector stakeholders as the representative samples for data collection. The most closely related stakeholders in this context, are the persons concerned with this aspect of the justice sector. This group includes the Judges, the public prosecutors, court clerks, file and record keepers of the court, and the defense lawyers. At the proposal stage, the work selected two districts of Bangladesh namely, Comilla and Pabna as the fields of study keeping in mind that the UNDP, Bangladesh is running pilot projects there to facilitate the justice sector by helping to reduce case backlog. As there is one tribunal in Comilla and another in Pabna dealing with the VAW cases, the number of sample stakeholders would be really small if this research would keep its scope limited in these two districts. However, considering that a moderate size of sample gives more generality to the current work, the research subsequently added Dhaka as an additional field for data collection as there are five Nari-o-Shishu Tribunals in this field. Lastly, the work takes a conscious determination that the sample is representative and not a non-representative or biased sample. It relies on the principle that how cases are selected for a sample is more important than how many cases are selected.

\subsection{MODEL QUESTIONNAIRE}

As the Research is following the mixed method approach, both Quantitative and Qualitative data analysis method are used. To the extent, the work is concerned with Qualitative data analysis, it takes the way of comparison of relevant literature and data. For the part of Quantitative data collection, the work selects 'Focus Group Interview' as its strategy. ${ }^{18}$ The interview is based on two sets of questionnaire. The first set consists of close ended questions. Previously formulated assumptions are placed as questions giving options of 'yes' or 'no' answers for the participants in the interview. ${ }^{19}$ This approach helps the work to gather numerical figures making the findings scientific. As it is a socio-legal research, a complete reliance on the Quantitative method may not

\footnotetext{
${ }^{17}$ Firebaugh, above n 8.

18 Ranjit Kumar, Research Methodology: A Step-By-Step Guide for Beginners (Pearson Education Australia, Sydney, 2009) 117.

19 Data does not always remain in quantitative form. Many data that do not naturally appear in quantitative form can be collected in quantitative way. Yes/No questionnaire helps social scientists to get numerical figures which are otherwise unavailable. For details see: A definition of Qualitative Method by Aliaga and Gunderson (2000), referred by Mark Balnaves and Peter Caputi, Introduction to Quantitative Research Method (Sage Publications Limited, 2001).
} 
reveal all the related information. Keeping this limitation in consideration, the second set of questionnaire is prepared for open ended interview. In this part, the participant stakeholders can go beyond the 'yes'/ 'no' answers and can add information that the researchers might have been ignored. Thus, the data collection method followed by the present work is compact and is able to secure maximum authenticity of the research finding.

\subsection{ETHICAL CONSIDERATION GUIDELINES}

The present work follows the guidelines for researching violence against women developed by Mary Elsberg and Lori Heise. ${ }^{20}$ This guideline is recommended by the JSF Project funded by the UNDP Bangladesh office for this study. According to these guidelines, the current work relies on the principles of respect for all persons at all stages of the research process, minimizing harm to the respondents and research staffs, maximizing benefits to the participants and community, and balancing risks and benefits of research on violence against women. ${ }^{21}$

20 Ellsberg M, and Heise L. Researching Violence Against Women: A Practical Guide for Researchers and Activists (Washington DC, United States: World Health Organization, 2005).

21 Ibid. 


\section{CHAPTER 3 \\ LITERATURE REVIEW}

\subsection{LITERATURE REVIEW ON LOW CONVICITON RATE IN VIOLENCE AGAINST WOMEN CASES UNDER THE NARI-O-SISHU NIRJATAN DAMAN AIN 2000:}

A wide range of literature deals with the aspects of violence against women and criminal justice response in combating this offence. This research, however, focuses on the reasons for low conviction rate in the VAW cases in Bangladesh under the Nari-o-Sishu Nirjatan Daman Ain 2000. The purpose of the literature review, therefore, is to explore and assess firstly, the prevalence and dynamics of the VAW in Bangladesh, and secondly, the criminal justice response as well as the challenge of low conviction rate in this particular offense. From a review of the relevant literature on this issue, it is found that most of the literature generally investigate the problem of non-implementation of laws relating to the VAW, very few of them deal with the reasons for low conviction rate in the VAW cases and except one or two, none of them exclusively focuses on the VAW with regard to this particular Act.

\subsubsection{DYNAMICS OF VIOLENCE AGAINST WOMEN}

Radford, Freidberg and Harne observe that the feminist activists identify violence against women as central to the perpetuation of women's oppression by considering sexual assault, rape, sexual harassment, domestic violence and other forms of male violence as part of a continuum of violence against women and children. ${ }^{22}$ According to Kurg et al, violence against women is experienced by women of all ages and social classes, races, religions and nationalities all over the world. ${ }^{23}$ While finding out the reasons for the VAW, Brownmiller comments that violence against women includes both the result of gender inequality and the means by which it is perpetuated in a cultural and political framework in which women are not the equal partners of men. $^{24}$

In this regard, considering violence against women as an issue of human rights, gender and developmental, Jeniffer L. Solotaroff and Rohini Prabha Pande observe that violence against women and girls in South Asia plays out in the historical, social and political contexts, where structures and functioning of government, social institutions and the law contribute to its

\footnotetext{
${ }^{22}$ Jill Radford, Lynne Harne, and Melissa Friedberg (eds), Women, Violence and Strategies for Action: Feminist Research Policy and Practice (Open University Press, 2000)2.

${ }^{23}$ World Health Organization: World Report on Violence and Health (2002)

$\langle$ http://www.who.int/violence_injury_prevention/violence/world_report>.

${ }^{24}$ Susan Brownmiller, Against Our Will: Women, Men and Rape (Penguin, 1975).
} 
persistence. ${ }^{25}$ More specifically, Reilly and McMillan say that violence against women is largely embedded in gender norms. Generally, the low status of women, economically, socially, culturally and politically tend to be responsible for the violation of basic rights of females by males in a society like Bangladesh. ${ }^{26}$ Hossain, Imran and Khair note that violence against women is largely the result of the perceived differences as to wealth, power and status between men and women as ascribed by the patriarchal norms. ${ }^{27}$ According to Gottfried, Gales and Loseke, sociological perspectives of resource theory and exchange theory show that power is largely based on resources and violence is the ultimate resource for securing compliance. In this model, violence against women tends to be a natural phenomenon. ${ }^{28}$ Khan and Aeron in their article clearly underline the interplay between gender equality, masculinity and violence against women. According to them, violence against women is a clear reflection of power imbalance in a society and can be seen as a way of establishing patriarchal norms in the society. While finding out the justification of violence against women they contend that in Bangladesh, like other patriarchal societies, men and women have been socialized to accept gender based violence. Such a norm not only helps to perpetuate violence but conditions women to accept it as a part of their lives. ${ }^{29}$ Seeing violence against women as a threat to the full realization of human rights and fundamental freedoms, Ameen observes that women in Bangladesh are victims of disparity, discrimination and exploitation which stem from the fact that gender has a camouflaging role, where human rights of women cannot be exercised in full. ${ }^{30}$

\subsubsection{CRIMINAL JUSTICE RESPONSE AND LOW CONVICTION RATE IN THE VAW CASES}

Zaman elaborately discusses on how the discriminatory attitude towards women is formed and institutionalized in Bangladesh to affect women's rights at different aspects of their life. She observes that a woman experiences neglect and various forms of discrimination and violence from the very moment of birth. These practices are tacitly condoned and are legitimized through laws and customs in the name of cultural and religious practices that blatantly and systematically

\footnotetext{
${ }^{25}$ World Bank: Violence against Women and Girls: Lessons from South Asia (2014) <https://openknowledge.worldbank.org/bitstream/handle/>.

${ }^{26}$ Niamph Reilly, Women's Human Rights: Seeking Gender Justice in a Globalizing Age (Polity Press, 2009); Also see: Lesley McMillan, Feminists Organizing against Gendered Violence (Palgrave, 2007).

${ }^{27}$ K.T. Hossain, M.H. Imam, S. Khair, Males' Perception on Violence against Women in Bangladesh (British Council, 2001).

${ }^{28}$ Heidi, Gottfried, 'Beyond Patriarchy? Theorizing Gender and Class' (1998) 32 Sociology 451; Also see: R Gells and DR Loseke (eds), Current Controversies on Family Violence (Sage, 1993) 182.

${ }^{29}$ M.E. Khan and Aditi Aeron, 'Prevalence, Nature and Determinants of Violence against Women in Bangladesh' (2006) 52 The Journal of Family Welfare 33.

${ }^{30}$ Nursat Ameen, 'Law and the State's Response towards Violence against Women' (2000) 4 Bangladesh Journal of Law 27.
} 
discriminate against women. ${ }^{31}$ Jahan, in this regard notes that gender inequality and its resolution in gender violence are embedded in the socioeconomic and political structures of Bangladesh. In many instances, not only is gender inequality practiced but also demonstrations of unequal power relations between sexes are encouraged in order to perpetuate the interest of the patriarchal order. Social attitudes regarding women's position and role have effectively contoured the space provided for the implementation of women's rights. Constitutional guarantees of equality before the law and equal protection by the law are not applied in practice. Rather, the ideology that creates and sustains the subordinate position of women within the family continues to inform judicial understanding and is reflected both in criminal and family laws concerning violence against women. ${ }^{32}$ As to its overall effect, Malik observes that enactment of laws without an adequate understanding of patriarchy and the impact of laws in the prevailing milieu of social constructions are reinforcing rather than reducing gender hierarchy and subjugation. ${ }^{33}$ Ameen mentions that an alarming increase of crime against women over the years indicates that the enforcement of laws that have been made to combat the VAW have not been encouragingly effective in the past years. ${ }^{34}$ In many instances of rape, molestation, abduction, and sexual harassment, technicalities and legal loopholes deprive women of justice, especially where the aggressors are in a dominant socio-economic position. ${ }^{35}$ Jahan in other words, observes that women's socio-economic powerlessness and ignorance of legal rights limit the scope of legal protection. In addition, litigation does not always guarantee that the desired judgment will be received. So far, imperfect understanding and inadequate knowledge of this multidimensional problem has produced limited success in this area. In many cases, full enforcement and implementation of existing laws have not been achieved due to various factors, including lack of awareness of women's rights among law enforcement agencies. The scarcity of effective agencies offering supportive intervention and the excessive expenses and timeconsuming process involved in litigation also prevent many women, especially, the poor and uneducated ones from seeking redress through criminal proceedings. ${ }^{36}$ Chowdhury identifies that although many laws exist in Bangladesh to address violence against women but because of ineffective implementation of these laws by the state and inherent conceptual defects in some of

\footnotetext{
31 Habiba Zaman, 'Violence against Women in Bangladesh: Issues and Response' (1999) 22 Women's Studies International Forum 37.

${ }^{32}$ Roushan Jahan, Family Violence and Bangladeshi Women: Some Observations, in Roushan Jahan and Latifa Akhanda (eds) Collected Articles, (Women for Women, 1983) 199.

${ }^{33}$ Malik, above n 3.

${ }^{34}$ Firebaugh, above $\mathrm{n} 8$.

${ }^{35}$ United Nations: Report of the Sub-regional Expert Group Meeting on Eliminating Violence against Women: Violence against Women in South Asia (United Nations, 2000) Report No.: ST/ESCAP/2099.

${ }^{36}$ Roushan Jahan, Hidden Danger: Women and Family Violence in Bangladesh (Women for Women, 1994$) 165$.
} 
them, such laws fail to punish the perpetrators of violence against women. These laws are thus useless and therefore, nothing but the ornamental additions to the statute books. ${ }^{37}$

Johnson, Ollus and Nevala find that several factors, such as, severity of the violence, injuries, use of force and weapons used as well as the evidentiary factors influence how case progress through the criminal justice system. And, the conviction rate in criminal cases depends on the legal system, magnitude of the case backlogs which may result in a higher level of the case dismissals at certain point throughput the criminal justice process, societal attitude toward sexual violence which exerts pressure on police and prosecutors to prioritize certain type of cases, the possibilities and mechanisms for cases to be withdrawn during the criminal justice process. ${ }^{38}$ The South African Law Commission Criminal Case Outcome Research Report notes that conviction rates are one way of telling us how well the criminal justice system is doing. It is particularly important for victims of violent crime that their attackers are convicted and appropriately punished. A criminal justice system that consistently fails to secure convictions has little credibility and there is a risk that victims may give up reporting crime and communities may instead resort to extra-legal, vigilante action. ${ }^{39}$ However, approach to criminal justice on the part of the victims largely depends on the belief that they have on the concerned law-enforcing agencies. Felson and Pare here find that victims of sexual assaults are less likely to report the violence than the physical assaults to the police is due to (a) a belief that the police could not do anything about the crime, (b) a fear that they would not be believed, (c) a fear of reprisal from the suspect, and (d) feelings of shame or embarrassment. ${ }^{40} \mathrm{~A}$ Report of the South Asia Regional Initiative and Equality Support Programme points out that to reduce the problem of low conviction in sexual assault cases, the Supreme Court of India categorically mentioned that the court (judge) should not be a silent spectator while the victim of the crime is being cross examined by the defense. The recording of evidence must be effectively controlled. Judges have gone ahead and provided support persons, in camera trials and other supportive measures to the victims to ensure that they do not continue to be persecuted during the trial process. The report then notes that despite all these, the conviction rate remains alarmingly low. ${ }^{41}$

\footnotetext{
${ }^{37}$ Elora Halim Chowdhury, 'Negotiating State and NGO Politics in Bangladesh: Women Mobilize against Acid Violence' (2007) 13 Violence against Women 857.

${ }^{38}$ Holly Johnson, Natalia Ollus and Sami Nevala, Violence against Women: An International Perspective (Springer, 2008).

${ }^{39}$ The South African Law Commission: Conviction Rates and other Outcomes of Crimes Reported in Eight South African Police Areas, Research Paper 82, <http://www.justice.gov.za/salrc/rpapers/rp18.pdf>.

${ }^{40}$ Richard B. Felson and Paul-Philippe Pare, 'The Reporting of Domestic Violence and Sexual Assault by Nonstrangers to the Police' (2005) 67 Journal of Marriage and Family 597.

${ }^{41}$ The South Asia Regional Initiative and Equality Support Programme: Landmark Judgments on Violence against Women and Children in South Asia (2005)

< http://www.childtrafficking.com/Docs/judge_woman_childvio_0607.pdf>.
} 
By examining the country studies on Bangladesh, India and Nepal, the Yearbook of the United Nations provides that the lack of implementation of laws aimed at ending violence against women was reflected in the low conviction rates for perpetrators of violent crimes against women. ${ }^{42}$ In this context, an UNDP study finds that in Bangladesh, the rate of convictions for violence against women is much lower when compared to the average rate of convictions (70\% of all cases in the country). ${ }^{43}$ Based on the data from 1998-2007, a BRAC research report shows that that rape cases have the lowest conviction rate. Besides, it is the least reported case and has the highest number of pending cases among the VAW cases. ${ }^{44}$ According to an UNDP report attributes that the lack of conviction is improper and ineffective investigations by the police. ${ }^{45}$ Other reasons for the failure to punish rape are lack of awareness of the law and lack of resources to make use of the legal system. ${ }^{46}$

The National Human Rights Commission of Bangladesh in its Baseline Survey on Human Rights in Bangladesh demonstrates that low conviction rate in the criminal justice system leads to the denial of justice for many victims of crime, especially, women and other marginalized groups. The report exemplifies this observation by noting one of the evidences from its household and qualitative surveys where all the interviewees in the focus group on violence against women stated that when they tried to lay charges against their husbands, they had been implicated in a false case. Even after they sought legal protection, their husbands managed to avoid justice by paying officials to buy their way out of the system. ${ }^{47}$ This is also important to understand one of the factors of low conviction rate. Malik indicates the harshness of laws in limiting the discretionary power of the judges. Placing no option before the judges this may lead to the low rate of conviction. He cites the Indian context where it has been argued that harsher laws have created a negative reaction among the judiciary, because these provisions have gone against the broader trends in legal reform and liberal interpretation of fundamental rights. ${ }^{48} \mathrm{He}$, therefore, contends that the fact that less than $10 \%$ of the cases under Nari-o-Sishu Nirjatan Daman

\footnotetext{
${ }^{42}$ United Nations, Yearbook of the United Nations (2002) <http://unyearbook.un.org/>.

${ }^{43}$ United Nations Development Programme (UNDP): Human Security in Bangladesh: In Search of Justice and Dignity (2002) <http://www.un-bd.org/undp/hsr/cover.pdf Dhaka>.

${ }^{44}$ BRAC: The Legal Challenges on the Way to Judicial Remedy in Rape Cases: The Role of Human Rights and Legal services Programme of BRAC (2009) <http://www.lib.unimelb.edu.au/recite/citations/AGLC/ref621elecSourceInternetMaterials>.

45 UNDP: Human Security in Bangladesh, Dhaka, September 2002, pp. 107-108.

${ }^{46}$ Human Rights Watch: Ravaging the Vulnerable, Abuses against persons at high risk of HIV Infection in Bangladesh (2003) <http://www.hrw.org/reports/2003/08/19/ravaging-vulnerable>.

${ }^{47}$ National Human Rights Commission of Bangladesh, Perceptions, Attitudes and Understanding: A Baseline Survey on Human Rights in Bangladesh (2011)

$<$ http://www.communitylegalservice.org/publication/a\%20baseline\%20servey\%20on\%20hr\%20of\%20bangladesh.p df. $>$.

${ }^{48}$ Flavia Agnes, 'Violence against Women: Review of Recent Enactments' in Swapna Mukhopadhay (ed), In the Name of Justice: Women and Law in Society, Delhi, (1998), at p. 80, cited in Malik, above n 3.
} 
(Biswes Bidhan) Ain, 1995 (earlier Act of Nari-o-Sishu Nirjatan Daman Ain 2000), are ending in conviction is a telling indication of the approach of the judiciary. Tania notes that the legislature in Bangladesh has responded to the VAW with a set of rigorous and draconian laws based on the notion that harsh laws will automatically reduce the VAW. But in practice, these laws are being misused to wreck vengeance, and to serve proprietary and other personal interests. ${ }^{49}$ In addition, Chowdhury observes that lack of funds for collecting and preserving evidence, lack of adequate protection of the victims and witnesses, improper documentation of testimony, and lack of understanding and sensitivity of violence against women issues among police, judges, doctors, and social workers all contribute to lack of punishment of the perpetrators of violence against women and inadequate redress to the victims of such violence. ${ }^{50}$

\subsection{LEGISLATIVE INCONSISTENCY}

In the United Nation's Handbook for Legislation on Violence against Woman ${ }^{51}$ it is suggested that legislations on violence against women should be revised time to time to ensure that all acts of violence against women are prohibited. It is also provided that, legislations in this respect should be comprehensive, multidisciplinary, criminalizing all forms of violence and encompassing issues of prevention, protection, survivor, empowerment and support as well as adequate punishment for perpetrators and availability of remedies for survivors. ${ }^{52}$ Legislations on violence against women have sometimes contain provisions, and/or been applied by the justice system in a manner, which discriminates between different groups of women. It is recommended that legislations should state that where there are conflicts between customary and/or religious laws and the formal justice system, the matter should be resolved with respect for the human rights of the survivor and in accordance with gender equality standards. ${ }^{53}$ The handbook particularly mentions that the conflicting and inconsistent legal provisions should be amended to ensure a consistent legal framework on the issue of violence against women. ${ }^{54}$ For that end, the VAW legislations should provide for the creation of specialized courts guarantying timely and efficient handling of the VAW cases. ${ }^{55}$

\footnotetext{
${ }^{49}$ Sharmin Jahan Tania, 'Special Criminal Legislation for Violence against Women and Children-A Critical Examination' (2007) Bangladesh Journal of Law 199.

${ }_{51}^{50}$ Firebaugh, above $\mathrm{n} 8$.

${ }^{51}$ United Nations (UN) Handbook, Department of Economic and Social Affairs, Division for the Advancement of Women, United Nations, New York, 2010, < www.un.org/womenwatch>.

${ }_{53}^{52}$ Ibid.

${ }^{53}$ UN Handbook, above n 51.

${ }^{54}$ Ibid.

${ }^{55}$ UN Handbook, above n 51.
} 
In the United Nations publication, "Ending Violence against Women from Words to Action" "56, concern is expressed on the scope and coverage of existing legislations on Violence against Women all over the world. Definitions of rape and domestic violence in most of the legislations are criticized for requiring force instead of lack of consent for rape and only addressing physical violence in case of domestic violence. Criminal legislations are criticized on the following grounds: (i) the termination of criminal proceeding upon withdrawal of case by victim, (ii) provisions for mitigating sentence in rape cases if the rapist marries the victim, (iii) inadequate punishment for crimes relating to violence against women and (iv) treating violence against women as crimes against honor or decency rather to treat it as a crimes against women's right to bodily integrity. ${ }^{57}$

In the United Nations report of the expert group meeting on "Good practices in legislation on violence against women " 58 it is provided that the legislations on violence against women should clearly set specific legislative goal. ${ }^{59}$ Setting clear legislative goal may prevent any further confusion or inconsistency among legislations. The report also stresses on continuous consultation with relevant stakeholders for the development of legislations on violence against women. ${ }^{60}$ It is also important to keep the VAW legislations under constant review and continue to reform it in the light of new information and understanding and for that evidence based approach is suggested to be followed. ${ }^{61}$

From Bangladesh context, inconsistencies in the VAW legislations have been often criticized in the Bangladesh Law Commission's reports. In one report on laws relating to sexual harassment, consistency in legal provisions is recommended in respect of provisions relating to sexual harassment as provided in section 509 of the Penal Code 1860 and sections 9 and 10 of the Nario-Shishu Nirjatan Daman Ain 2000. ${ }^{62}$ In another report of Bangladesh Law Commission dated $05 / 10 / 2010$, it is provided that the conviction rate in the VAW cases under the Nari-o-Shishu Nirjatan Daman Ain 2000 is only 10\% in an average which indicates that there are loopholes in the provisions of this legislation. ${ }^{63}$ This report suggests that in practice, there should be consistency in the provisions relating to granting bail under section 19 of the Nari-o-Shishu Nirjatan Daman Ain 2000 and under section 417 of the Code of Criminal Procedure 1898. Particularly, in the GR cases, the cases remain at the Magistrate's Court till the submission of Police report and the Nari-o-Shishu Nirjatan Daman Ain does not keep any provision that

56 UN Publication, Ending Violence against Women from Words to Action Study of the Secretary General, (United Nations Publication, 2006).

57 Ibid.

58 United Nations report of the expert group meeting, Good practices in legislation on violence against women, (the United Nations Office at Vienna, Austria, 2008).

59 Ibid

60 UN Report, above n 58.

61 Ibid.

62 The Law Commission of Bangladesh: A report dated 25/08/2010 (2010)

<http://www.lawcommissionbangladesh.org/reports/98.pdf>

63 The Law Commission of Bangladesh: A report dated 05/10/2010 (2010),

<http://www.lawcommissionbangladesh.org/reports/99.pdf> 
confers power to the Magistrates to grant bail at this stage. During this time, the Magistrates can grant bail invoking section 497 of the Code of Criminal Procedure 1898.

However, as the present research specifically focuses on the four VAW legislations, e.g., the Nari-o-Shishu Nirjatan Daman Ain 2000, the Dowry Prohibition Act 1980, the Domestic Violence Act 2010 and the Family Courts Ordinance 1985, the work could not find any direct literature specifically commenting on the inconsistencies among these legislations. Therefore, the present research develops certain hypothesis on the basis of the abovementioned general guidelines for the ideal VAW legislations. The literature review in summary suggests that, to be consistent, the VAW legislations should be specific about scope and goal. The legislations should comprehensively deal with the issues and should avoid conflicting provisions. From procedural context, the VAW legislations should clearly mention the powers of the relevant adjudicating authorities at every stage of the trial. 


\section{CHAPTER 4 \\ CONCEPTUAL FRAMEWORK}

\subsection{VIOLENCE AGAINST WOMEN}

Being one of the world's most compelling social problems, gender-violence, particularly, violence against women requires a broad definition to encompass a wide variety of oppressions suffered by women. ${ }^{64}$ The underlying reasons is, "narrow definitions not only exacerbate the problem of underreporting, but also trivialize women's real life abuses' ${ }^{65}$ by ultimately preventing them to seek social and legal support. Therefore, it is suggested that in addition to focusing on the perspective of the victim, the definition of violence against women should cover a wide spectrum of abuses that include both the use of force and the threat to compel or constrain women to behave or not to behave in given ways. The definition should also include the intention of perpetuating hierarchical gender-relations in all social structures behind the use of force. ${ }^{66}$ Thus, any violation of a woman's basic rights on the ground of gender can be termed as an act of violence. ${ }^{67}$ In respect of its scope, violence against women is defined as an act of aggression that occurs in both personal and social contexts and thus, it includes women's experience of violence both inside and outside of the home. ${ }^{68}$ Besides, so far the forms of violence against women are concerned, attempts to broaden the definition demonstrate that as psychological abuse can just be as injurious as physical violence, this should be included within the scope of violence against women. ${ }^{69}$

In line with these observations, the Declaration on the Elimination of All Forms of Violence against Women adopted by the United Nations General Assembly in 1993 identifies violence against women as a violation of the rights and fundamental freedoms of women. ${ }^{70}$ The Deceleration defines violence against women as ".....any act of gender-based violence that results in, or is likely to result in, physical, sexual and psychological harm or suffering to women, including threats of such acts, coercion or arbitrary deprivation of liberty, whether occurring in public or in private life" ${ }^{71}$. This definition seems to be comprehensive as it embraces but is not limited to physical, sexual and psychological violence occurring in the family, within the general community or the violence perpetrated or condoned by the state.

Types of Violence: Following this definition, the forms of violence as specifically mentioned in the Declaration include battery, sexual abuse of female children in the household, dowry

\footnotetext{
${ }^{64}$ Kathleen Barry, Female Sexual Slaver (New York University Press, 1984), BRAC cited in An Assessment of Male Attitude Towards Violence Against Women (2003)

<http://research.brac.net/others/an_assessment_of_male_attitude_towards_violence_against_women_pdf.pdf.>.

${ }^{65}$ Raquel Kennedy Bergen, 'Marital Rape: New Research and Directions' (2006) VAW Net 1.

${ }^{66}$ Asia Pacific Forum on Women, Law and Development, Kuala Lampur: Asia-Pacific women's Issues, Law and the Development Process, 'My Rights, Who Control?' (1990), cited by Barry in above n 64.

${ }_{68}^{67}$ RA Baron, Human Aggression (Plenum Press, 1984) cited in above n 66.

${ }^{68}$ Zaman, above $\mathrm{n} 31,37$.

${ }^{69}$ AE Adams et al, 'Development of the Scale of Economic Abuse' (2008) 15 Violence against Women 563.

${ }^{70}$ The Declaration on the Elimination of Violence against Women 1998, A/RES/48/104, Preamble.

${ }^{71}$ Ibid, Article 1.
} 
related violence, marital rape, female genital mutilation and other traditional practices harmful to women, non-spousal violence, violence related to exploitation, sexual abuse, sexual harassment and intimidation at work, in educational institutions and elsewhere, trafficking of women and forced prostitution. ${ }^{72}$ This definition, however, does not claim to be all-inclusive and recognizes that various other forms of violence exist around the globe. The declaration is, therefore, somewhat arbitrary in that it does not provide sufficient guidance regarding controversial issues such as, whether control over a woman's reproductive rights constitutes violence against women. Nevertheless, despite its backdrop, the Declaration offers the first internationally accepted definition of violence against women and a strong basis for the struggle to eliminate gender violence around the world. Besides, violence against women has been classified in terms of six recognized forms of abuse, e. g., physical, social, verbal, social, financial and spiritual. ${ }^{73}$

Like other South Asian countries, violence against women is a complex and common social phenomenon in Bangladesh due to deeply rooted patriarchy and unequal gender norms. Although the rate of reported data on violence against women has been consistently increasing, especially since the early 1990s but a set of comprehensive statistics is still unavailable as many cases remain unreported. ${ }^{74}$ Following the major trends in violence, domestic violence, dowry related violence, rape, trafficking, acid throwing, forced prostitution, victimization by fatwa have been identified as the common forms of violence against women in Bangladesh. ${ }^{75}$

\subsection{CRIMINAL JUSTICE RESPONSE TOWARDS VIOLENCE AGAINST WOMEN}

Bangladesh has ratified the core international instruments on women's rights such as the Convention on the Minimum Age for Marriage, Registration of Marriage and Consent to Marriage, 1962 and the Convention on the Elimination of all Forms of Discrimination against Women 1979 (CEDAW) respectively in the year of 1998 and 1984. Apart from these general treaties, Bangladesh is internationally committed to uphold women's rights and, therefore, to prevent violence against women by being a party to the International Covenant on Civil and Political Rights (ICCPR), and the International Covenant on Economic, Social and Cultural Rights (ICESCR) which emphasize on the principle of non-discrimination and equality between male and female. The Government of Bangladesh is also committed to implement other international standards and goals that address gender equality, such as, the Beijing Declaration and Platform of Action and the United Nations Millennium Development Goals. At national level, the Constitution of Bangladesh in the chapter on Fundamental Rights underlines the

\footnotetext{
${ }^{72}$ Ibid, Article 2.

73 Shalu Nigam, 'Silent Enemy in the Home' (2002) 49 Social Welfare 8, cited in BR Sharma and Manisha Gupta, 'Gender Based Violence in India: A Never Ending Phenomenon' (2004) 6 Journal of International Women's Studies 114.

${ }^{74}$ Sharmeen A. Farouk, 'Violence against women: A statistical overview, challenges and gaps in data collection and methodology and approaches for overcoming them' (Paper presented at the Expert Group Meeting, UN Division for the Advancement of Women in collaboration with Economic Commission of Europe and World Health Organization, Switzerland, 11-14 April 2005).

75 Ibid; above n 47, 40.
} 
principles of non-discrimination and equality among all the citizens irrespective of sex. Article 28(4), however enables the state to make special provision for women.

As a criminal justice issue, within the legal frameworks violence against women requires penal provisions to deal with the offences violating women's rights. In this regard, the Penal Code 1860 has specific provisions for rape, kidnapping, abduction of women, acid throwing and attempt to cause death or grievous hurt. Sexual assault and marital rape are still outside the purview of the code. In addition to the Penal Code, the country has a series of special laws to prevent violence against women. The most significant among them, are, the Children Act 1974, the Dowry Prohibition Act 1980, the Nari-o-Sishu Nirjatan Daman Ain 2000, the Acid Control Act 2002, the Acid Crime Control Act 2002, and the Domestic Violence (Prevention and Protection) Act 2010, and the Human Trafficking Deterrence and Suppression Act 2012. However, these laws have been criticized as nothing but the 'ornamental addition to the statue books ${ }^{76}$ for having a very limited effect on the face of the high rate of violence against women. For the purpose of this project, it is found that the Act of 2000 has repealed the Nari-o-Sishu (Bishesh Bidhan) Ain 1995, which previously repealed the Cruelty to Women (Deterrent Punishment) Ordinance 1983. To strictly suppress oppression against women, some of the crimes punishable under the Nari-o-Shishu Nirjatan Daman Ain 2000 are trafficking of women and children, causing death for dowry, confinement of any woman or children for taking ransom, causing death or hurt by gang rape, etc. To date, for the trial and punishment of the criminals accused of committing crimes under the Nari-o-Sishu Nirjatan Daman Ain 2000, more than 30 special tribunals have been set up in several districts of the country. These tribunals are popularly known as the Nari-o-Sishu Nirjatan Daman tribunals and the number is on increase. ${ }^{77}$

\subsection{CONVICTION RATE IN THE VAW CASES}

Conviction rate means the ratio of cases ending in conviction out of the total number of cases decided in a given year. Hence, it is a reasonably good indicator of the efficiency and efficacy of the criminal justice system prevailing in a particular country. ${ }^{78}$ Unlike detection rate which measures the success of investigation, "conviction rate measures the efficiency of the prosecutor's office ${ }^{79}$ and the success of trial. ${ }^{80}$ As it 'measures punishments in crime rate regression ${ }^{, 81}$, therefore, an attempt to identify conviction rate is particularly important for the victims of violent crimes to ensure that their attackers are convicted and appropriately punished. Broadly, from the criminal justice perspective, the main objective of the criminal trial is to determine whether an accused person has violated the penal law and if found guilty, to prescribe

\footnotetext{
${ }^{76}$ Chowdhury, above n $37,857$.

${ }^{77}$ Malik, above n 3, 1.

${ }^{78} \mathrm{http}: / / w w w . u n a f e i . o r . j p / e n g l i s h / p d f / R S \_N o 53 / N o 53 \_31 R C \_G r o u p 3 . p d f, 24.02 .2015$.

79 American Prosecutors Research Institute, Do Lower Conviction Rates Mean Prosecutors' Offices are Performing Poorly? (2007) http://www.ndaa.org/pdf/do_lower_conviction_rates_07.pdf.

${ }^{80}$ Ted Leggett, 'The Sieve Effect: South Africa's Conviction Rates in Perspective'(2003) 5 SR Crime Quarterly 11.

${ }^{81}$ David B. Mustrad, 'Reexamining Criminal Behaviour: The Importance of Omitted Variable bias' (2003) 85 The Review of Economics and Statistics 205.
} 
the appropriate sanction. ${ }^{82} \mathrm{~A}$ criminal justice system that consistently fails to secure convictions has little credibility. As a result of which the victims may give up to report the crimes and the communities may instead resort to some extra-legal, vigilante actions. It is not true that the conviction rate is the only appropriate performance measure of any criminal justice system. In fact, too narrow a focus on the conviction rate can be detrimental to the interests of justice. For instance, in a Constitutional democracy, the police is not permitted to break the law themselves in order to obtain a conviction at any cost; it is also not in the interest of justice to prosecute all the cases. The principle of fairness implies that an accused must be acquitted if reasonable doubt exists about their guilt. Therefore, there are other important considerations than the conviction rates in assessing how effective and just any particular criminal justice system is. However, the progress and outcome of the cases provide with a ready barometer to evaluate systemic performance which can be indicated by the rate of conviction. ${ }^{83}$ Differences in the conviction rates occur due to a number of factors, e.g., the legal framework, the law enforcement infrastructure, the quality and role of the personnel operating within the legal system, etc. A high conviction rate although is not the primary objective of the criminal justice system, but, it may be indicative of the methodical and painstaking investigations and effective prosecution. By contrast, an excessively low conviction rate definitely indicates unsuccessful and ineffective prosecution. Under the four heads, namely, investigation, prosecution, trial, and legal and systemic framework, several other factors have been identified to list the potential reasons for low conviction rate, generally in criminal cases, as follows: ${ }^{84}$

\section{Chart: Reasons for the Low Conviction Rate}

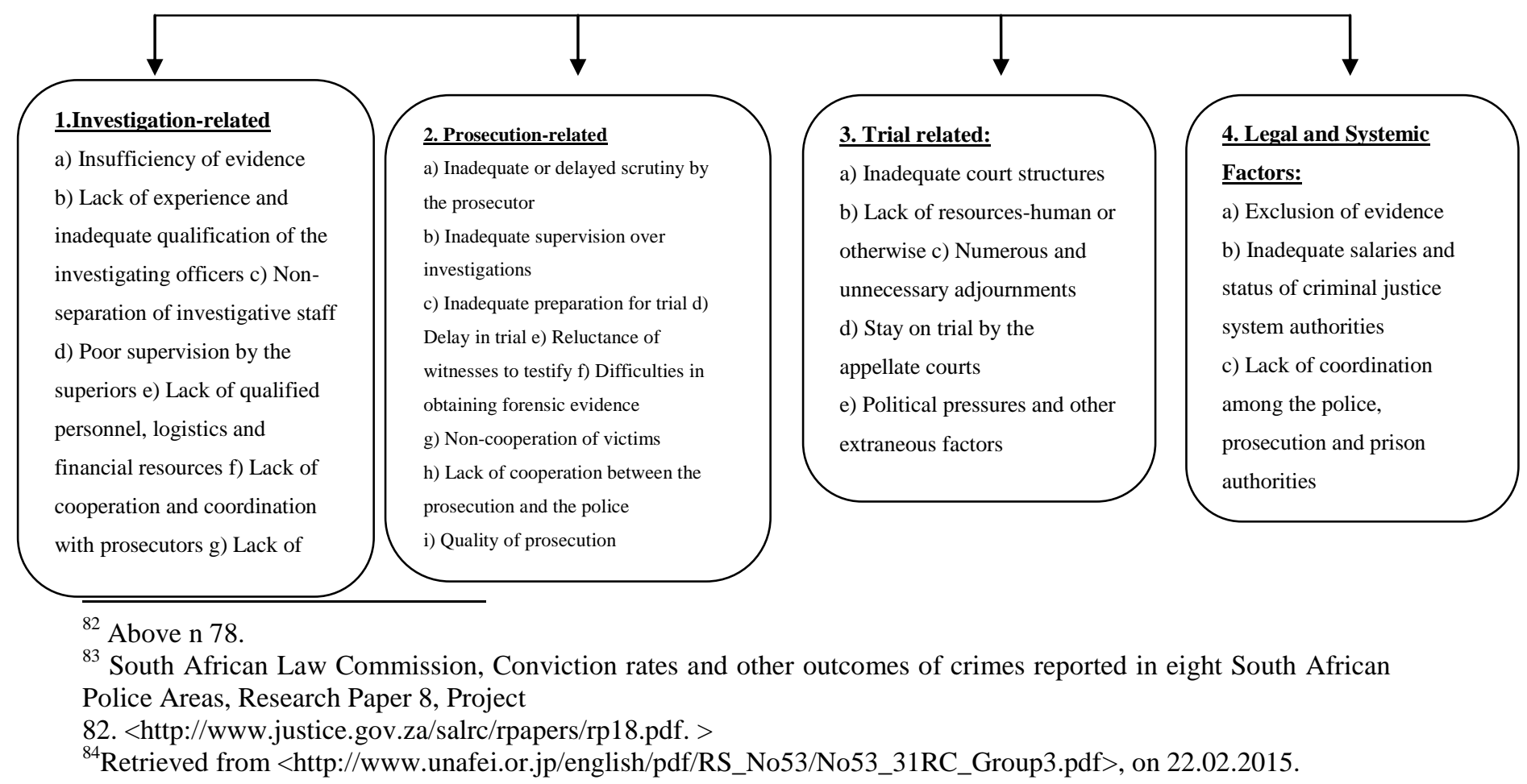


By analyzing the dynamics and challenges of the violence against women cases in Bangladesh, Chowdhury observes that lack of funds for collecting and preserving evidence, protecting the victims and witnesses, improper documentation of testimony, lack of understanding and sensitivity of violence against women issues among police, judges, doctors, and social workers all contribute to acquittal of the perpetrators of violence against women and inadequate redress to the victims of such violence ${ }^{85}$, particularly, poor and disadvantaged women. In many cases, 'due to harassment and complexities of the court procedure, the victims are often compelled to accept out of court settlement ${ }^{86}$ which may contribute to low conviction rate.

\section{Framework used in this study:}

Conviction rates can be explained from two perspectives, i.e., trial-based perspective and reportbased perspective. The trial based perspective measures the conviction rate in terms of the numbers of cases that go to trial. The later approach focuses on the number of cases reported to the police. The trial based perspective is criticized for 'ignoring many reported crimes that do not reach to the trial stage if they were undetected by police or withdrawn from the court before trial' ${ }^{87}$ The present study will focus on this perspective in spite of its limitations for two reasons. Firstly, in comparison to the report-based perspective, it will ensure easy and available access to data from the Nari-o-Shishu Tribunal of violence against women under the Nari-o-Sishu Nirjatan Daman Ain 2000. Secondly, the trial based approach will analyse the challenges that influence low conviction rate during the trial of the VAW cases in the Nari-o-Sishu Tribunals by focusing on the inter-play among the justice sector agencies and their role.

\subsection{LEGISLATIVE INCONSISTENCY IN THE VAW CASES}

The second issue addressed by this research is the inconsistencies in the four specific VAW legislations namely, The Dowry Prohibition Act 1980, the Nari-o-Shishu Nirjatan Daman Ain 2000, the Domestic Violence (Prevention and Protection) Act 2010 and the Family Courts Ordinance 1985. This issue is taken up for consideration on the basis of the recommendations from the VAW Roadmap Conference undertaken by the Justice Sector Facility (JSF) Project funded by the UNDP Bangladesh in 2014 being thus placed for further investigation.

There are general criticisms against the lacunas of the legislations dealing with violence against women. For example, Tania in her writing has commented that the VAW related laws are too

\footnotetext{
${ }^{85}$ Chowdhury, above n 37, 857.

${ }^{86}$ Ibid.

${ }^{87}$ Above n 83, 9.
} 
rigid, harsh and draconian adopted on the wrong notion that harshness of law reduces violence against women. ${ }^{88}$ Again, Malik ${ }^{89}$ criticized harshness of special criminal laws dealing with VAW in limiting the judge's discretionary power finding it responsible for the low conviction rate in the VAW cases. It is also argued that generally harshness of laws hinders legal reform and liberal interpretation of the fundamental rights. ${ }^{90}$ Thus, it can be inferred that the legislative lacunas in piecemeal special legislations can affect the whole administration and access to justice. However, in this work, the general lacunas in the VAW legislations are not addressed but one specific kind of lacuna that is legislative inconsistency is taken up for consideration.

The justifiability and feasibility of research on this concept of legislative inconsistency may be illustrated by the following instances of substantive and procedural inconsistencies in the provisions relating to dowry contained in the Dowry Prohibition Act 1980 and the Nari O Shishu Nirjatan Daman Ain 2000.

The Dowry Prohibition Act, 1980 provides punishment for the offences of giving, taking ${ }^{91}$ and demanding dowry ${ }^{92}$. The offences under this legislation are non-cognizable, non-bailable and compoundable. ${ }^{93}$ Cognizance, Conviction and Sentence can be passed by a Magistrate of First Class for any offence punishable under this Dowry Prohibition Act, 1980. ${ }^{44}$ However, this law does not address any other dowry related offence or offences of other kinds which may be resulted from the demand of dowry. Interestingly, section 11 of the Nari-o-Shishu Nirjatan Daman Ain, $2000^{95}$ rather penalizes the offences of attempt of causing death for dowry, causing death of any woman for dowry and causing grievous or simple hurt in the demand of dowry. The offences under the Nari-o-Shishu Nirjatan Daman Ain, 2000 are cognizable and bailable. ${ }^{96}$ Bail shall not be given unless the Complainant is heard on the matter of bail. ${ }^{97}$ The offences under this Act of 2000 are supposed to be tried by the special Nari-o-Shishu Nirjatan Daman Tribunals to be constituted under the provisions of this Act. ${ }^{98}$ Therefore, for the similar and related offences concerning dowry, two legislations prescribe two different forums as well as they impose different characteristics on the offences regarding grant of bail and about being cognizable or non-cognizable. Thus, on the issue of dowry, Nari-o-Shishu Nirjatan Daman Ain,

88 Tania, above n 49, 199.

89 Malik, above $\mathrm{n} 3$.

90 Malik, above n 3, .

${ }^{91}$ Act No. XXXV of 1980, s 3.

${ }^{92}$ Act No. XXXV of 1980, s 3.

${ }^{93}$ Act No. XXXV of 1980 , s 8.

${ }^{94}$ Act No. XXXV of 1980. S 7.

${ }^{95}$ Act No. 8 of 2000, s 11.

${ }^{96}$ Act No. 8 of 2000, s 19.

${ }^{97}$ Act No. 8 of 2000, s 19.

${ }^{98}$ Act No. 8 of 2000, s 20. 


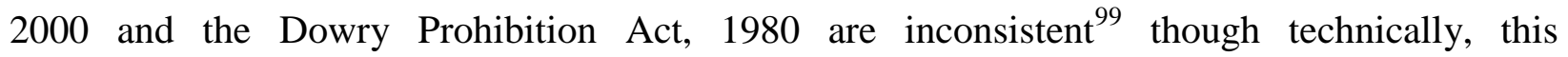
inconsistency may not be called as a 'contradiction'. ${ }^{100}$

Again, there are intra-legislative inconsistencies in the Nari-o-Shishu Nirjatan Daman Ain 2000. The Magistrate Court remains as the appropriate Court for granting interim-bail in GR Cases pending submission of Police Report. However, the Nari-o-Shishu Nirjatan Daman Tribunal takes cognizance of the case under section 19 of the said Act but cannot give bail before the Police Report is submitted. ${ }^{101}$ In a previous High Court Division judgment reported in $B L T$ (HCD) XVII 2009 (192) it was held that, by a harmonious reading of sections 19 and 27 of the Nari-o-Shishu Nirjatan Daman Ain, 2000, it is clear that before the nature of the case is determined by the Police Report, the Nari-o-Shishu Nirjatan Daman Tribunal cannot hear bail matters rather it may be heard by the Courts of Judicial Magistrates or Metropolitan Magistrates. If bail is not granted by the Magistrate's Court, appeal may be preferred to the Sessions Court under the provisions of the Code of Criminal Procedure 1898. ${ }^{102}$

An opposite stance in this respect was taken by the High Court Division of Bangladesh Supreme Court in the cases reported in 56 DLR 279, 24 BLD 236, 13 BLT 302, 9 MLR 173, 24 BLD 205 and 11 BLC $436 .{ }^{103}$ In these judgments, it was held that the Nari-o-Shishu Nirjatan Daman Tribunal can hear the bail matters even before the investigation is complete. This view was supported by the Appellate Division's judgment reported in 29 DLR SC 236 and 13 BLD (AD) 94 wherein it was held that any criminal case begins from the lodgment of the first information report and therefore the concerned Court or Tribunal should have jurisdiction to hear bail matters from the very beginning of the case. ${ }^{104}$ Therefore, the Nai-o-Shishu Nirjatan Daman Ain 2000 apparently keeps open the scope of confusion in this regards.

On the other hand, the titles of the Domestic Violence Act 2010 and the Nari-o-Shishu Nirjatan Daoman Ain 2000 (Women and Children Anti Repression Act 2000) may give rise to confusions. Both of these legislations address the issues concerning violence against women. However, the Domestic Violence Act addresses physical abuse, psychological abuse, sexual

\footnotetext{
${ }^{99}$ The term, "inconsistency" is used in the sense that inconsistency that hinders harmonious or smooth operation giving rise to confusions.

${ }^{100}$ It was held by Appellate Division of the Supreme Court of Bangladesh in the Constitution $8^{\text {th }}$ Amendment Case Judgment that, two things are said to be conflictive or contradictory when they cannot operate together simultaneously. For details see: The Constitution $8^{\text {th }}$ Amendment Case Full Judgment by the Appellate Division reported in 1989 BLD (Spl.) 1.

${ }^{101}$ The Law Commission, Bangladesh: The Recommendations on Clarification of Jurisdiction of Courts to Grant Bail till Submission of Police Report in the cases filed under Nari-o-Shishu Nirjatan Daman Ain 2000 (2012) <http://www.lc.gov.bd/reports/115-Women\%20and\%20Child\%20Ain,\%202000.pdf>.

102 (2009) BLT (HCD) XVII 192.

${ }^{103}$ Ibid.

${ }^{104}$ Ibid.
} 
abuse and economic abuse of women by any member of her family. ${ }^{105}$ The Nari-o-Shishu Nirjatan Daman Ain covers the aspects of physical and sexual abuse of women in section 10 generally. Under the Domestic Violence Act 2010 the victim can get help from the Police and the Enforcement Officers. Under section 4 of the Domestic Violence Act 2010, the Police is supposed to inform the victim of her rights to get relief under different laws and her right to get other facilities. Therefore, the scope, objective and purposes of these two legislations are different. But the similarity in the titles and subject matters may mislead the victims to take recourse to the most appropriate and beneficial legislation in this respect.

From the above discussion, it is clear that the issue of legislative inconsistency is required to be addressed from the perspectives of its probable impacts on the access and administration of justice as well as on the issue of case backlog. For that purpose, the present research considers legislative inconsistencies in the VAW legislations from three dimensions.

Firstly, the work will find out whether there is any substantive inconsistency in the provisions of the abovementioned VAW legislations. For example, the work will investigate into the inconsistencies and overlap in the scope, jurisdiction and subject matters of the VAW legislations.

Secondly, the work will investigate whether there is any procedural inconsistency in the VAW legislations. For example, the work will look into whether the VAW legislations confer jurisdiction to more than one Special Court or Tribunal to try the same or similar offence or liability. The research will also investigate into the impact of different Courts or Tribunals dealing with the same or similar offences at different stages of the trial process.

Thirdly, the present research will investigate into the VAW Cases filed and tried under inappropriate provisions of law and about the VAW proceedings being quashed on the ground of being tried by the Courts without having jurisdiction. This aspect is addressed because the trial of cases by inappropriate forums is one of the signs of inconsistencies in the VAW legislations. If more than one legislation simultaneously address the same or similar offences or subject matters, that may result into a misconstruction of law and jurisdiction by the concerned Courts or Tribunals.

Lastly, the present work will examine whether the legislative inconsistencies in the VAW legislations are giving rise to multiplicity of proceedings and lodgment of proceedings to the inappropriate Courts thereby resulting into Case backlogs. Naturally, if the proceedings are initially initiated in an inappropriate forum, it ultimately results into wastage of time and

\footnotetext{
${ }^{105}$ The Domestic Violence Act 2010, s 3.
} 
resources. Filing of the VAW Cases in inappropriate Court requires the concerned Court to apply its mind and to transfer the same to the appropriate Court resulting in delay to dispose as well.

The present research on legislative inconsistencies will thus be based on the abovementioned conceptual framework. Through the Quantitative data analysis and Qualitative research, recommendations will be drawn by this work on the necessity of any legislative amendment of VAW legislations. The work will also comment on whether the piecemeal special VAW legislations should be complied into a single comprehensive code bringing all the VAW related matters under the jurisdiction of one specific Court. 


\section{CHAPTER 5 \\ DATA ANALYSIS AND FINDINGS ON LOW CONVICTION RATE IN THE VAW \\ CASES}

This part critically examines the level of low conviction rate in the VAW cases under the Nari-oSishu Nirjatan Daman Ain 2000 and the underlying reasons behind with reference to the quantitative and qualitative data. During the initial literature review it has been found that conviction rate in the VAW cases is abysmally low. Following this, section- 1 of this chapter tests the level of this rate by illustrating firstly, the quantitative survey result from the justice sector agencies of Dhaka, Comilla and Pabna and secondly, by analyzing the statistics on the VAW cases filed at the Nari-o-Sishu Nirjatan Daman Tribunals of the abovementioned three districts. If section- 1 finds that the conviction rate is really low, then section- 2 will look for the underlying reasons for low conviction. Current research has gone through several literatures and found no single study on this particular topic. Rather, they either have focus on the reasons for low conviction rate in criminal cases, in general or in the VAW cases, in particular. However, based on those literatures, this research hypothesizes some reasons behind the low conviction rate in the VAW cases under the 2000 Act. To testify those hypotheses, this research primarily relies on the quantitative and qualitative questionnaire based survey result. Besides, judgments of the Supreme Court and the Trial Court in the VAW cases are examined for specifically determining the reasons behind the low rate of conviction.

\subsection{SECTION-1: IS THE CONVICTION RATE LOW IN THE VAW CASES?}

Hypothesis: Conviction rate is extremely low in the VAW cases under the Nari-o-Sishu Nirjatan Daman Ain 2000.

Question asked: Is the conviction rate in the VAW cases under the Nari-o-Sishu Nirjatan Daman Ain 2000 generally low?

Quantitative data: The 24 justice sector agencies, e.g., judges, public prosecutors and defense lawyers of all the Nari-o-Sishu Tribunals in Dhaka, Comilla and Pabna who have been interviewed during the field visit of this research unanimously have opined that the cases filed at the Nari-o-Sishu Tribunal generally have an extreme low rate of conviction. However, the magnitude varies as per the nature of the offence. According to majority of the participants, the offence of causing death or attempting to cause death for dowry [Section 11(a)], causing grievous hurt for dowry [Section 11(b)], causing simple hurt for dowry [section 11(c)] have the lowest rate of conviction. By contrast, kidnapping (section 7), rape [section 9(a)], causing death after rape [section 9(b)], causing death or hurt by gang rape [section 9(c)] have the highest rate of conviction. The finding, however, contradicts with the statement that the offence of rape has the 
lowest rate of conviction. Besides, being a very much gender-sensitive issue in a patriarchal society it is the least reported crime and has the highest number of pending cases. ${ }^{106}$

This finding is confirmed by the statistics collected from the said tribunals. This confirmation is significant to show the actual level of 'extreme low rate of conviction'. It is to be mentioned that due to unavailability of data, among all the tribunals, data of Tribunal-1 on the total number of case, pending case and disposed case, number of acquittal and conviction is not included in the following tables and graphs.

Table 1: Consolidated data from Nari-o-Shisu Nirjatan Daman Tribunals of Dhaka, Comilla and Pabna.

\begin{tabular}{|c|c|c|c|c|c|c|c|c|c|}
\hline$\stackrel{\Xi}{\circlearrowright}$ & 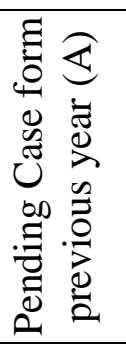 & $\begin{array}{l}\widehat{\theta} \\
0 \\
0 \\
0 \\
0 \\
0 \\
0 \\
\tilde{U} \\
\tilde{U}\end{array}$ & $\frac{m}{ \pm}$ & 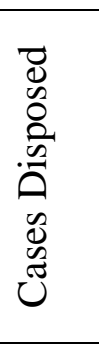 & $\begin{array}{l}\stackrel{\infty}{\Xi} \\
: \\
\tilde{\Xi} \\
0 \\
\tilde{D} \\
\tilde{U} \\
\tilde{U}\end{array}$ & 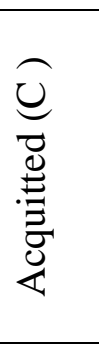 & 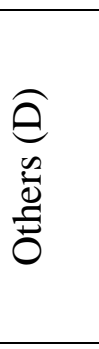 & 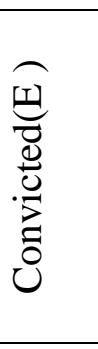 & 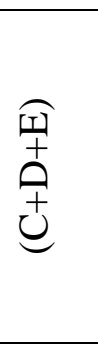 \\
\hline 2014 & 14474 & 5910 & 20384 & 4542 & 15842 & 2032 & 2707 & 19 & 4758 \\
\hline 2013 & 13256 & 6188 & 19444 & 4970 & 14474 & 1838 & 1818 & 15 & 3671 \\
\hline 2012 & 11997 & 5538 & 17535 & 4279 & 13256 & 2314 & 1944 & 27 & 4285 \\
\hline 2011 & 10865 & 4164 & 15029 & 3032 & 11997 & 1727 & 1273 & 23 & 3023 \\
\hline 2010 & 9359 & 4148 & 13507 & 2642 & 10865 & 2040 & 1044 & 48 & 3132 \\
\hline 2009 & 8727 & 3240 & 11967 & 2608 & 9359 & 2103 & 652 & 54 & 2809 \\
\hline
\end{tabular}

The above table shows the total number of cases filed at the Nari-o-Shisu Nirjatan Daman Tribunals operating in Dhaka, Comilla and Pabna from 2009 to 2014. Over the span of 6 years, total number of pending cases has increased from 8727 to 14474 and number of cases disposed has also increased from 2608 to 4542 but no such trend was evident in the number of conviction. In 2009, the total number of conviction was 54 which declined to 19 in 2014.

106 Above n 44, 5. 
Table 2: Percentage of Disposal, Non-Conviction and Conviction for the year 2009 to 2014

\begin{tabular}{|c|c|c|c|}
\hline Year & $\begin{array}{c}\text { Percentage of Case } \\
\text { Disposal }\end{array}$ & $\begin{array}{l}\text { Percentage of Non- } \\
\text { Conviction }\end{array}$ & Percentage of Conviction \\
\hline 2014 & $22.28 \%$ & $99.60 \%$ & $0.42 \%$ \\
\hline 2013 & $25.56 \%$ & $99.59 \%$ & $0.30 \%$ \\
\hline 2012 & $24.40 \%$ & $99.37 \%$ & $0.63 \%$ \\
\hline 2011 & $20.17 \%$ & $99.24 \%$ & $0.76 \%$ \\
\hline 2010 & $19.56 \%$ & $98.47 \%$ & $1.82 \%$ \\
\hline 2009 & $21.79 \%$ & $98.08 \%$ & $2.07 \%$ \\
\hline
\end{tabular}

Overall, this table shows that over the 6-year period from 2009 to 2014, there was a fluctuant trend in the percentage of case disposal. By contrast, the percentage of conviction starting from $2.07 \%$ in 2009 showed a decreasing trend up to 2013. Looking at the detail, among all the years, 2013 had the highest rate of disposal which was $25.56 \%$ with the lowest rate of conviction of $0.30 \%$. Likewise, 2012 although had the second highest rate of disposal, the conviction rate in that year scored the second lowest. By contrast, the lowest rate of disposal was in the year of 2010 which was $19.56 \%$. But, during that year, the conviction rate of $1.82 \%$ was the second highest among all the mentioned years. Significantly, a slight increase in the conviction rate was evident in 2014 which was $0.42 \%$ with the disposal rate of $22.28 \%$. 


\section{Chart 1: Comparison between Number of Cases and Disposal}

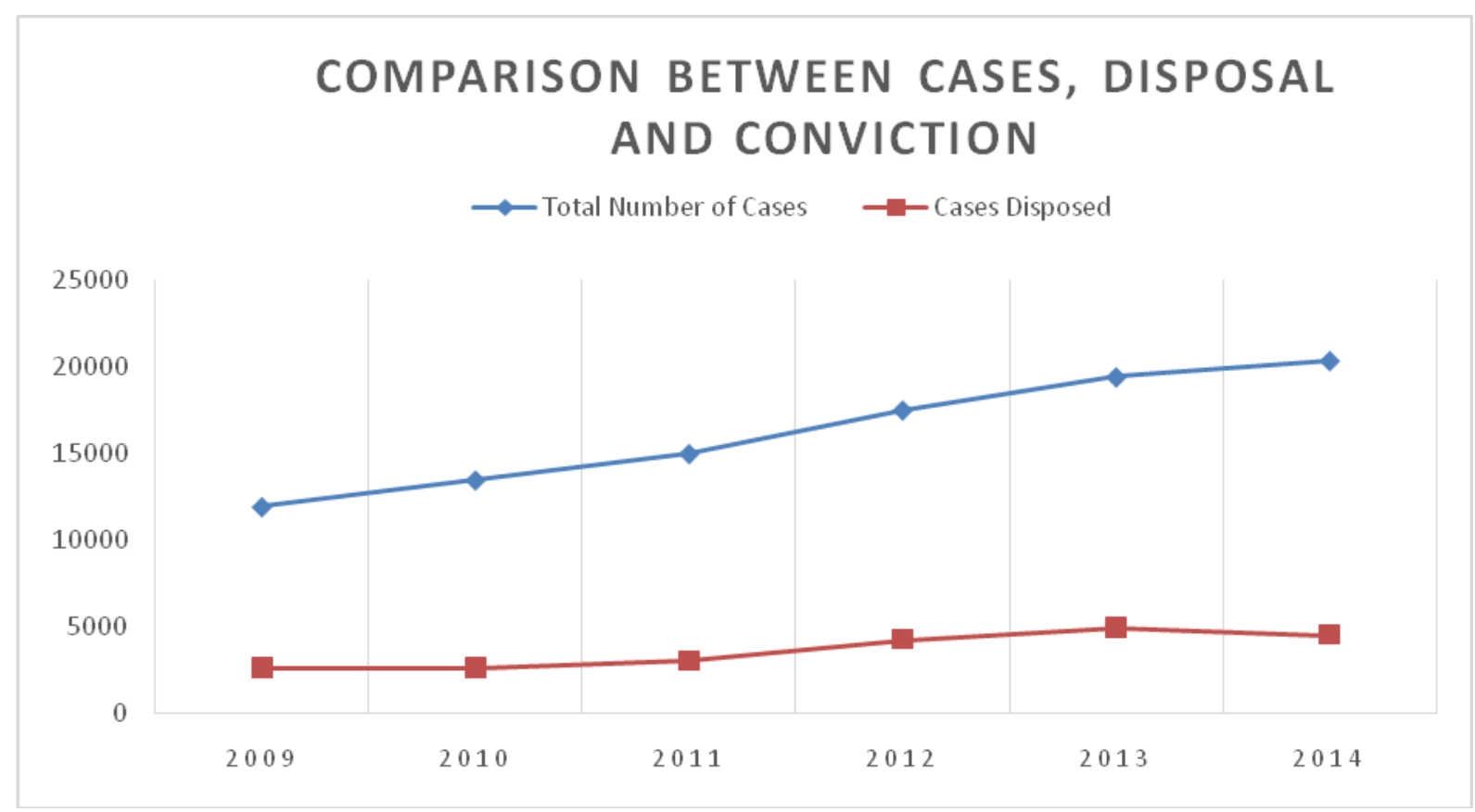

This graph clearly shows that there was a positive trend in the total number of cases and the number of cases disposed. In 2009, in a number of 11967 total cases, the number of disposed case was 2608. In the following years, the number of total cases increased gradually and in 2014, it was 20384. The number of disposed case from 2009 to 2014 also followed an upward trend with a slight fluctuation in 2014. Therefore, the number of disposed case of 2608 in 2009 increased to 4907 but subsequently decreased in 2014 with a number of 4542 . In comparison to all these numbers, the number of cases that ordered conviction was so low that this graph could not include within its limit. For example, in 2009, the number of conviction was 54 which over the years although had a fluctuating trend with a very small number, remarkably decreased in 2014, it was only 19. This was, however, a slight increase from 2013 which had a number of 15 convictions. 


\section{Chart 2: Comparison among Acquittal, others (Dismissal, Withdrawal) and Conviction}

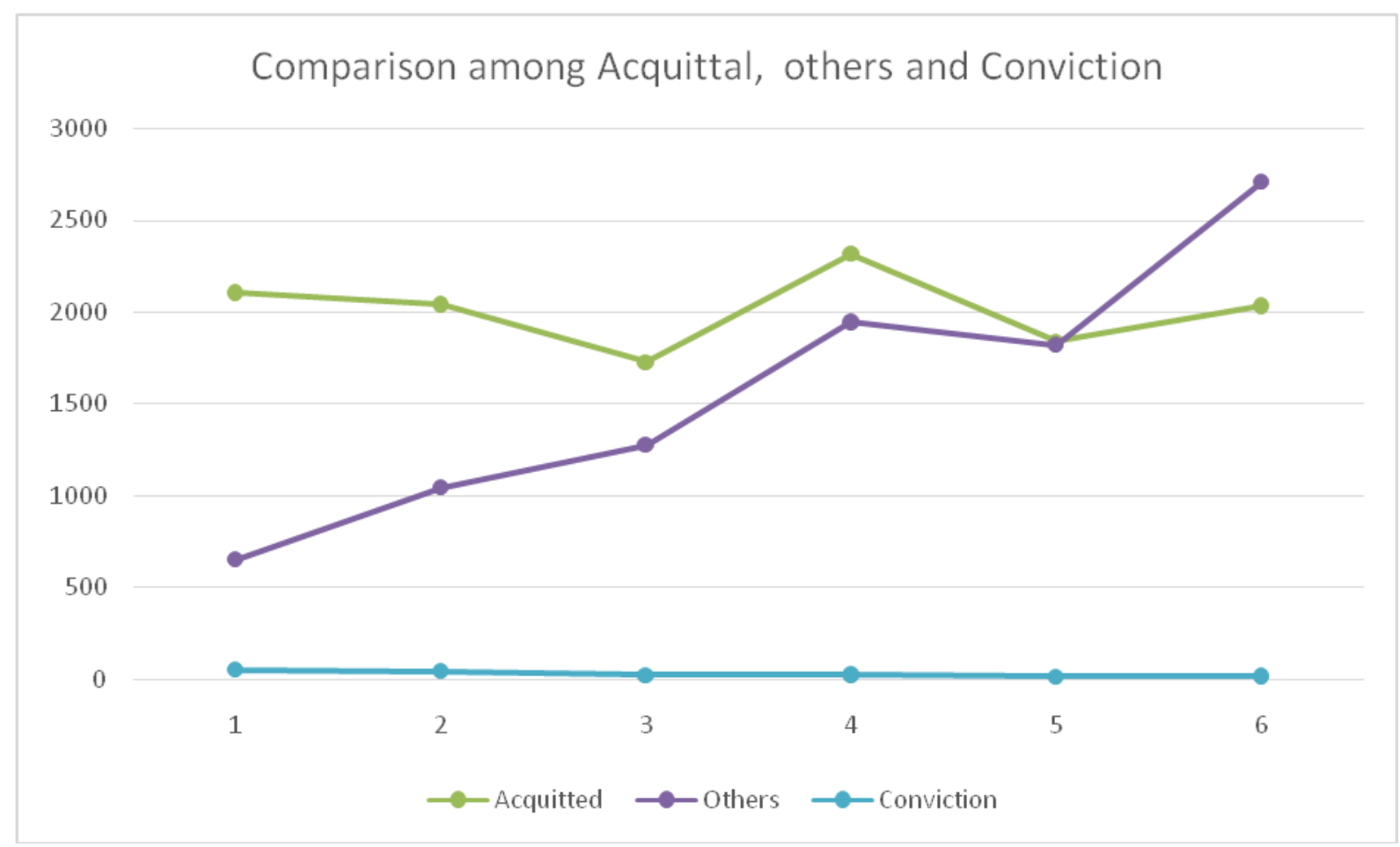

This another way of showing the statistics of Table 1 graphically indicates that the line showing the number of conviction, in comparison to the number of acquittal and others (e.g., withdrawal) is so low that it is visually merged to the $\mathrm{x}$ axis. To elaborate further, while the numbers of acquittal and others were respectively 2103 and 652 in 2009, the number of conviction was only 54. As has been shown in the earlier graph, that the number of conviction, except decreased over the years and in 2014 it was 19. By contrast, the numbers of acquittal and others saw an upward trend and in 2014 they were 2032 and 2707.

The summarized data can be shown in the following table. 
Table 3: Summary of data for the year of 2009 to 2014

\begin{tabular}{|c|c|c|}
\hline & $\begin{array}{l}\text { Total } \\
\text { Number }\end{array}$ & Percentage \\
\hline Filed cases & 37915 & \\
\hline Cases Disposed & 22073 & $58.22 \%$ \\
\hline Acquitted \& Others & 21492 & $99.14 \%$ \\
\hline Convicted & 186 & $0.86 \%$ \\
\hline
\end{tabular}

From 2009 to 2014, the overall conviction rate of all the Nari-o-Shisu Nirjatan Daman Tribunals of Dhaka, Comilla and Pabna was only $0.86 \%$ in comparison to the percentage of non-conviction which was $99.14 \%$.

\section{Chart 3: Summary of data for the year of 2009 to 2014}

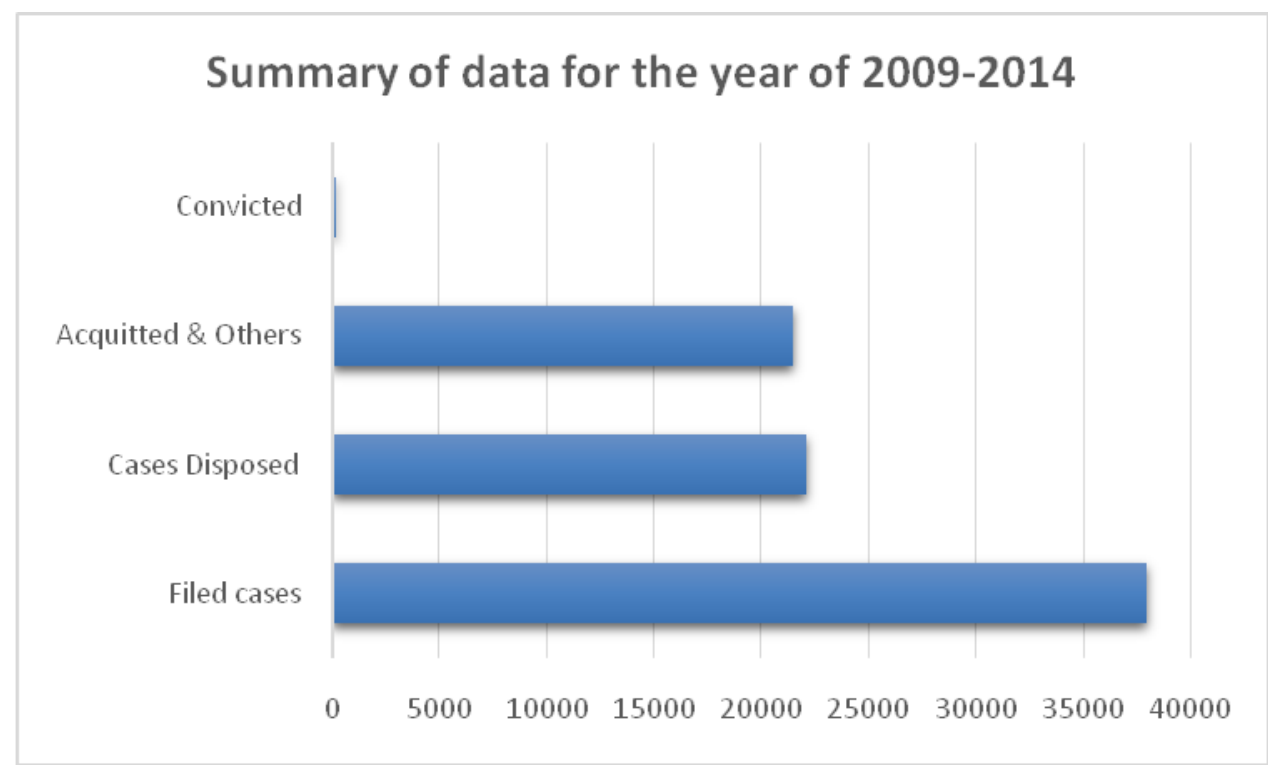

Following Table 3, the above bar chart clearly shows the low rate of conviction rate in the Nario-Shisu Nirjatan Daman Tribunals of Dhaka, Comilla and Pabna in comparison to the total number of filed cases, disposed cases and others (e.g., withdrawn). Statistics show that, from 2009 to 2014, from 37915 filed cases, the number of disposed cases was 22073 with a percentage of $58.22 \%$ and the numbers of acquittal and others were 21492 , the percentage of which was $99.14 \%$. The conviction rate, however, was only $0.86 \%$ with a number of 186 convictions. 


\section{2. SECTION 2: REASONS FOR LOW CONVICITON RATE:}

To find out the underlying reasons behind the low conviction rate in the VAW cases under the Nari-o-Sishu Nirjatan Daman Ain 2000 this research hypothesizes the following factors.

\section{Hypothesis on the reasons for low conviction rate in the VAW cases (For quantitative and qualitative data collection)}

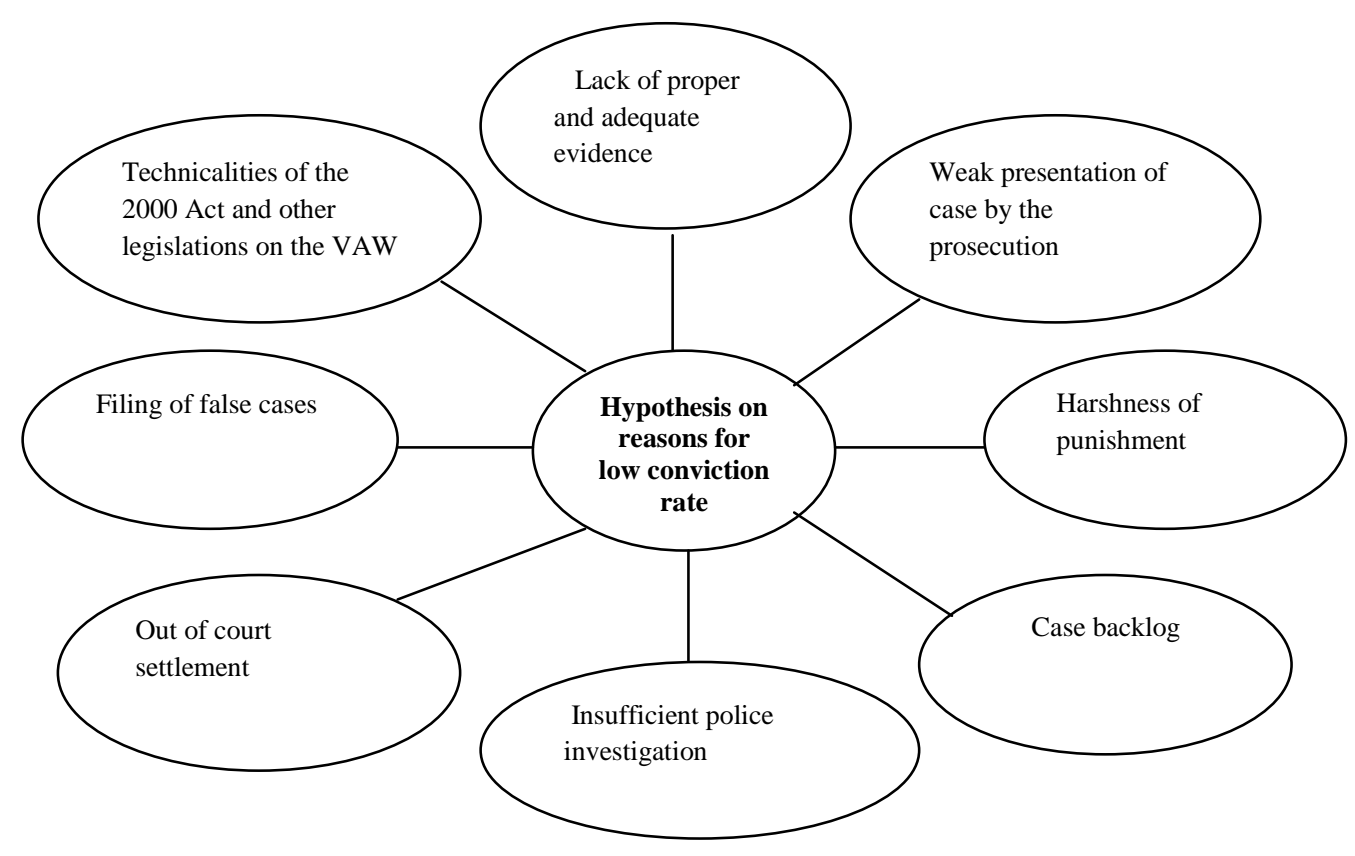

\subsubsection{ANALYSIS OF THE QUALITTAIVE AND QUANTITATIVE DATA FROM THE NARI-O-SISHU NIRJATAN DAMAN TRIBUNALS:}

The following discussion attempts firstly, to test these hypotheses by analyzing the quantitative and qualitative data collected from the justice sector agencies of the Nari-o-Shisu Nirjatan Daman Tribunals of Dhaka, Comilla and Pabna. In its concluding part, this analysis looks for identifying the most significant reason behind the low conviction rate in the VAW cases. Secondly, judgments of the Supreme Court and the brief cases studies from the tribunals are examined to verify the reasons as stated by the justice sector agencies. 
(i) Analysis of the Quantitative and Qualitative Data of the Nari-o-Sishu Nirjatan Daman Tribunals of Dhaka, Comilla and Pabna:

\section{$\underline{\text { Hypothesis } 1}$}

Lack of proper and adequate evidence is a reason for low conviction rate in the VAW cases under the Nari-o-Sishu Nirjatan Daman Ain 2000.

\section{Question asked:}

(i) Do you find that lack of evidence as a reason for low conviction rate in the VAW cases?

\section{Quantitative Data Table on Hypothesis No. 1}

\begin{tabular}{|l|c|c|c|c|}
\hline $\begin{array}{l}\text { Categories } \\
\text { of } \\
\text { participants } \\
\text { interviewed }\end{array}$ & \multirow{2}{*}{$\begin{array}{l}\text { Affirmative } \\
\text { answers }\end{array}$} & $\begin{array}{c}\text { Negative } \\
\text { answers }\end{array}$ & \multicolumn{2}{|c|}{ Other } \\
\cline { 4 - 5 } & 6 & 2 & 0 & 0 \\
\hline Judges & 7 & 2 & 0 & 0 \\
\hline $\begin{array}{l}\text { Public } \\
\text { Prosecutors }\end{array}$ & 6 & 1 & 0 & 0 \\
\hline $\begin{array}{l}\text { Defense } \\
\text { Lawyers }\end{array}$ & & NA \\
\hline
\end{tabular}

Total No. of participants interviewed: 24

Total No. of affirmative answer: 19

Total No. of negative answer: 5

Total No. of qualitative answer: 0

Qualitative Data Table on Hypothesis No. 1

\begin{tabular}{|c|c|}
\hline Categories of Participants & $\begin{array}{l}\text { Summary of qualitative answers on Hypothesis } \\
\text { No. } 1\end{array}$ \\
\hline Judges, Public Prosecutors and Lawyers & $\begin{array}{l}\text { 1. In general, medical officers and doctors } \\
\text { cannot be found and they do not cooperate } \\
\text { 2. Doctors often provide false and fabricated } \\
\text { report by taking money from the victim or } \\
\text { the accused person in their favor } \\
\text { 3. Sometimes, victims (women) get harassed } \\
\text { while collecting medical evidence, } \\
\text { especially victim of rape } \\
\text { 4. Consent by the victim at the time of rape } \\
\text { because of promise of marriage, a bar to } \\
\text { collecting medical evidence } \\
\text { 5. Medical examinations are not executed in } \\
\text { a timely manner } \\
\text { 6. Sometimes forensic evidence is }\end{array}$ \\
\hline
\end{tabular}




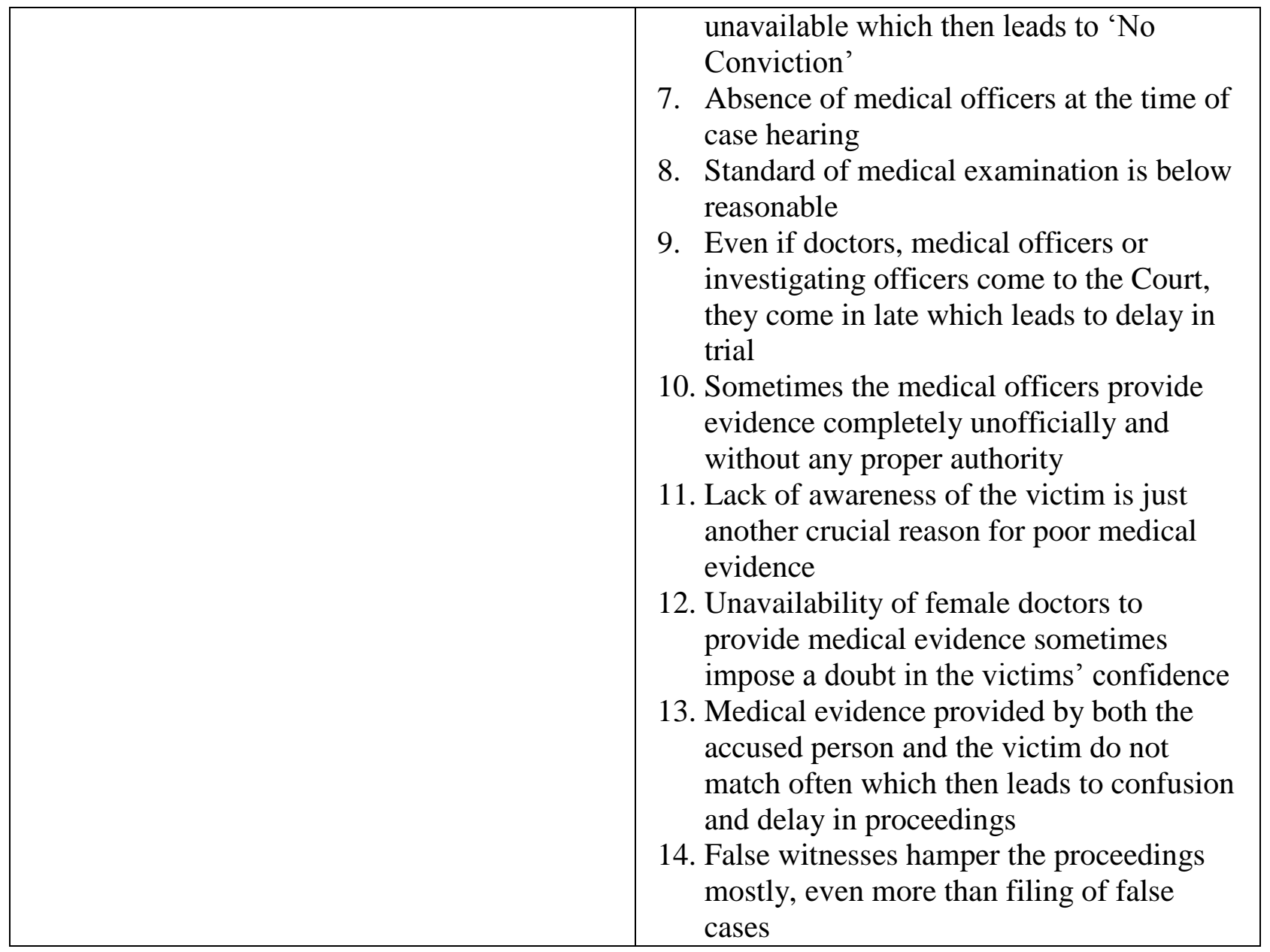

\section{Finding on Hypothesis 1}

The quantitative data reveals that 19 among 24 participants have found lack of evidence as a reason for low conviction rate in the VAW cases. And the qualitative data points out that among all types of evidence, medical evidence is mostly unavailable or if available, appear as false and fabricated in many cases. The unavailability of medical evidence occurs either because the doctor or medical officer cannot be found or they do not cooperate. Medical examinations are also not executed in a timely manner. This lead to delay in the examination of witness and trial. The offence that is mostly affected by inadequate medical evidence is rape. Another interesting point that has been found is that the evidence of false witnesses hampers the VAW proceeding, even more than filing of false cases. 


\section{Hypothesis 2}

Weak presentation of the prosecution case negatively affects the conviction order of the trial court.

\section{Question asked:}

(i) Do you find the prosecution lawyers playing satisfactory role?

Quantitative Data Table on Hypothesis No. 2

\begin{tabular}{|l|c|c|c|c|}
\hline $\begin{array}{l}\text { Categories } \\
\text { of } \\
\text { participants } \\
\text { interviewed }\end{array}$ & $\begin{array}{l}\text { Affirmat } \\
\text { ive } \\
\text { answers }\end{array}$ & \multirow{2}{*}{$\begin{array}{c}\text { Negativ } \\
\text { e } \\
\text { answers }\end{array}$} & \multicolumn{2}{|l|}{ Other } \\
\cline { 4 - 5 } & & & $\begin{array}{c}|l| \\
\text { A }\end{array}$ & NA \\
\hline Judges & 2 & 6 & 0 & 0 \\
\hline $\begin{array}{l}\text { Public } \\
\text { Prosecutors }\end{array}$ & 4 & 3 & 1 & 1 \\
\hline $\begin{array}{l}\text { Defense } \\
\text { Lawyers }\end{array}$ & 1 & 3 & 1 & 2 \\
\hline
\end{tabular}

Total No. of participants interviewed: 24

Total No. of affirmative answer: 7

Total No. of negative answer: 12

Total No. of qualitative answer: 5

$M A=$ Mixed Answer $/ N A=$ Not Answered

No. 2

Qualitative Data Table on Hypothesis

\begin{tabular}{|c|c|}
\hline Categories of Participants & $\begin{array}{l}\text { Summary of qualitative answers on Hypothesis } \\
\text { No. } 1\end{array}$ \\
\hline Judges, Public Prosecutors and Lawyers & $\begin{array}{l}\text { 1. Public prosecutors are negligent and } \\
\text { insincere } \\
\text { 2. There should be more senior and } \\
\text { experienced people appointed as PP } \\
\text { 3. They provide moderate cooperation } \\
\text { towards the victims } \\
\text { 4. There is minimal coordination between the } \\
\text { PPs and justice sector agencies } \\
\text { 5. Insufficient effort by PPs } \\
\text { 6. They tend to treat all the case with equal } \\
\text { weight unless there is some political } \\
\text { backing or the case is filed by any NGO } \\
\text { 7. Cooperation of PP mostly depends on the } \\
\text { person s/he is, if supportive or corruptive } \\
\text { 8. There should be legal accountability } \\
\text { measures implemented for the PPs } \\
\text { 9. Sometimes the cases suddenly come to PPs }\end{array}$ \\
\hline
\end{tabular}




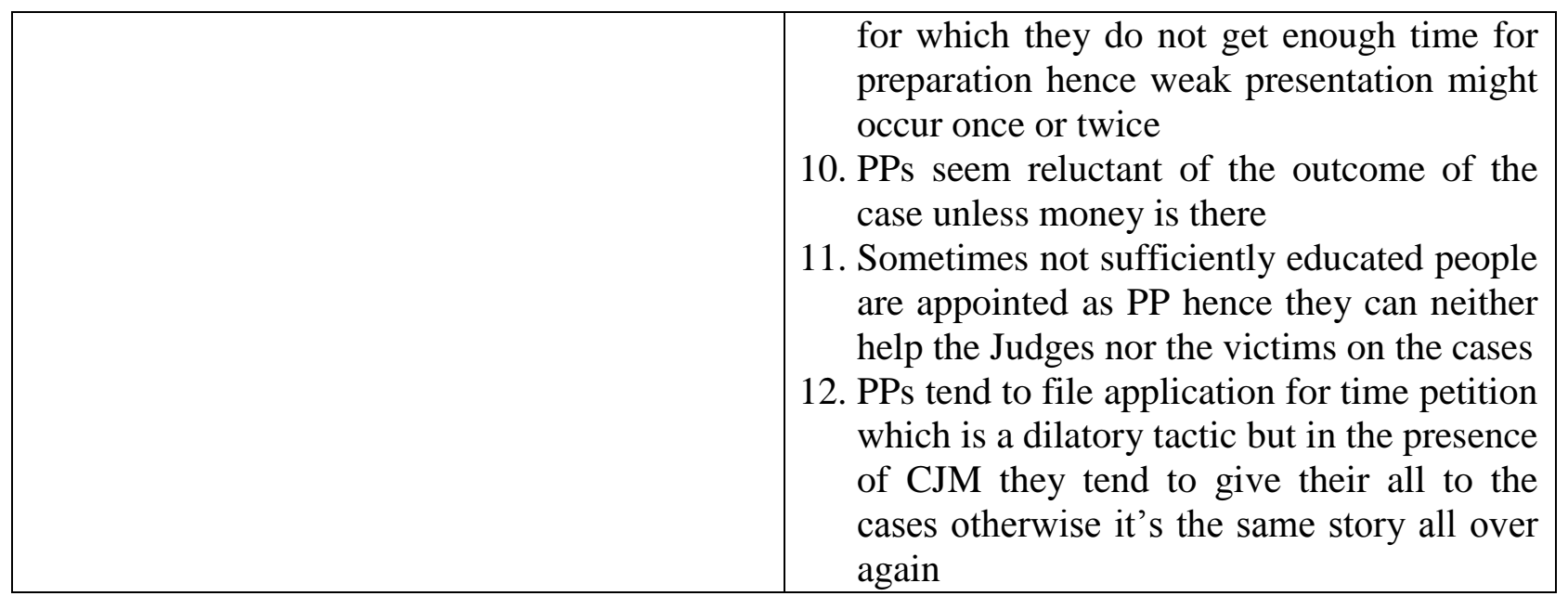

\section{Finding on Hypothesis 2}

The quantitative data shows that majority of the participants have responded with a negative answer. However, the qualitative data indicates four main reasons behind the weak presentation of the VAW cases by the PPs. While the first two relate to the negligence, insincerity and lack of proper legal knowledge of the PPs, the other two indicate the time constraint in preparing the prosecution case and lack of cooperation from the victim, witness or the justice sector agencies. To improve the current situation, qualitative data suggests for the appointment of more skilled and senior PPs and establishment of mechanism that will ensure accountability. 


\section{Hypothesis 3}

Harshness of punishment leads to no conviction.

\section{Question asked:}

(i) Do you find harshness of punishment under the 2000 Act is a reason for low conviction rate?

\section{Quantitative Data Table on Hypothesis No. 3}

\begin{tabular}{|l|l|c|c|c|}
\hline $\begin{array}{c}\text { Categorie } \\
\text { s of } \\
\text { participa } \\
\text { nts }\end{array}$ & $\begin{array}{l}\text { Affirmat } \\
\text { ive } \\
\text { answers }\end{array}$ & $\begin{array}{c}\text { Negativ } \\
\text { e } \\
\text { answers }\end{array}$ & \multicolumn{2}{|l|}{ Other } \\
\cline { 4 - 5 } $\begin{array}{c}\text { interview } \\
\text { ed }\end{array}$ & & $\begin{array}{c}\text { M } \\
\text { A }\end{array}$ & NA \\
\hline Judges & 2 & 6 & 0 & 0 \\
\hline $\begin{array}{l}\text { Public } \\
\text { Prosecuto } \\
\text { rs }\end{array}$ & 2 & 6 & 0 & 1 \\
\hline $\begin{array}{l}\text { Defense } \\
\text { Lawyers }\end{array}$ & 2 & 5 & 0 & 0 \\
\hline
\end{tabular}

Total No. of participants interviewed: $\mathbf{2 4}$

Total No. of affirmative answer: 6

Total No. of negative answer: 17

Total No. of qualitative answer: 1

MA = Mixed Answer $/$ NA = Not Answered

Qualitative Data Table on Hypothesis No. 3

\begin{tabular}{|c|l|}
\hline Categories of Participants & $\begin{array}{l}\text { Summary of qualitative answers on Hypothesis } \\
\text { No. } 1\end{array}$ \\
\hline Judges, Public Prosecutors and Lawyers & $\begin{array}{l}\text { 1. Non-bailable nature of laws regarding } \\
\text { VAW cases is good }\end{array}$ \\
& $\begin{array}{l}\text { 2. It only hampers justice when false cases } \\
\text { are filed to harass the husband }\end{array}$ \\
& $\begin{array}{l}\text { 3. Mandatory death sentence under the 2000 } \\
\text { Act leaves no alternative before the judges } \\
\text { amended with lesser punishment }\end{array}$ \\
\hline
\end{tabular}




\section{Finding on Hypothesis 3}

Only one-fourth of the total participants have positively answered that harshness of punishment under the Nari-o-Sishu Nirjatan Daman Ain 2000 is a reason for low conviction rate. The qualitative data, however, identifies two aspects of punishment to prove the harshness of the Act, e.g., non-bailability of offence and mandatory death penalty. According to the participants, harshness of law inspires the filing of false case when there is an intention to harass any party. Therefore, to prevent the abuse of justice harshness is recommended to be mitigated by legislative amendment.

\section{Hypothesis 4}

False case is a reason behind the low conviction rate in the VAW cases.

\section{Question asked:}

(ii) Do you think filing of false cases is one of the reasons for low conviction rate in the VAW cases?

Quantitative Data Table on Hypothesis No. 4

\begin{tabular}{|c|c|c|c|c|c|}
\hline \multirow{2}{*}{$\begin{array}{l}\text { Categorie } \\
\text { s of } \\
\text { participa } \\
\text { nts } \\
\text { interview } \\
\text { ed }\end{array}$} & \multirow{2}{*}{$\begin{array}{l}\text { Affirmat } \\
\text { ive } \\
\text { answers }\end{array}$} & \multirow{2}{*}{$\begin{array}{l}\text { Negativ } \\
\text { e } \\
\text { answers }\end{array}$} & \multicolumn{2}{|c|}{ Other } & \multirow{2}{*}{$\begin{array}{l}\text { Total No. of participants interviewed: } 24 \\
\text { Total No. of affirmative answer: } 21 \\
\text { Total No. of negative answer: } 3 \\
\text { Total No. of qualitative answer: } 0\end{array}$} \\
\hline & & & $\begin{array}{c}\mathrm{M} \\
\mathrm{A}\end{array}$ & NA & \\
\hline Judges & 8 & 0 & 0 & 0 & $M A=$ Mixed Answer $/ \mathrm{NA}=$ Not Answered \\
\hline $\begin{array}{l}\text { Public } \\
\text { Prosecuto } \\
\text { rs }\end{array}$ & 6 & 3 & 0 & 0 & \\
\hline $\begin{array}{l}\text { Defense } \\
\text { Lawyers }\end{array}$ & 7 & 0 & 0 & 0 & \\
\hline
\end{tabular}




\section{Qualitative Data Table on Hypothesis No. 4}

\begin{tabular}{|l|l|}
\hline Categories of Participants & $\begin{array}{l}\text { Summary of qualitative answers on Hypothesis } \\
\text { No. 1 }\end{array}$ \\
\hline Judges, Public Prosecutors and Lawyers & $\begin{array}{l}\text { 1. Filing of false cases is one of the most } \\
\text { crucial reasons for low conviction of } \\
\text { VAW cases }\end{array}$ \\
$\begin{array}{l}\text { 2. Often the victim files cases to harass } \\
\text { husband for petty reasons which could } \\
\text { have been solved between them in a } \\
\text { domestic environment }\end{array}$ \\
$\begin{array}{l}\text { 3. It is a medium for the victims to extract } \\
\text { money from the husband } \\
\text { The MO/IO often takes money to provide } \\
\text { false evidence so that false case may be } \\
\text { filed }\end{array}$ \\
$\begin{array}{l}\text { 5. False witnesses cause much problem as } \\
\text { well }\end{array}$ \\
$\begin{array}{l}\text { 6. Some lawyers even tend their victim to } \\
\text { this path to secure more money } \\
\text { Trial court should be cautious in taking } \\
\text { cognizance of an offence. }\end{array}$
\end{tabular}

\section{Finding on Hypothesis 4}

Majority of the participants believe that filing of false case under the Nari-o-Sishu Nirjatan Daman Ain 2000 is a reason for low conviction rate. The medical officer, investigation officer and even lawyers may have a part in preparing and presenting false cases. In this regard, the interviewees' have recommended that while taking cognizance of an offence, the trial court should be more cautious and should recourse to section 17 of the Act to punish anyone who files a false case. 


\section{Hypothesis 5}

Technicalities of the 2000 Act and other legislations influence the court not to issue a conviction order.

\section{Question asked:}

(i) Do you think that technicalities of laws are one of the reasons for low conviction rate in the VAW cases?

\section{Quantitative Data Table on Hypothesis No. 5}

\begin{tabular}{|c|c|c|c|c|c|}
\hline \multirow{2}{*}{$\begin{array}{c}\text { Categorie } \\
\text { s of } \\
\text { participa } \\
\text { nts } \\
\text { interview } \\
\text { ed }\end{array}$} & \multirow{2}{*}{$\begin{array}{l}\text { Affirmat } \\
\text { ive } \\
\text { answers }\end{array}$} & \multirow{2}{*}{$\begin{array}{l}\text { Negativ } \\
\mathrm{e} \\
\text { answers }\end{array}$} & \multicolumn{2}{|c|}{ Other } & \multirow[b]{2}{*}{$\begin{array}{c}\text { Total No. of participants interviewed: } \mathbf{2 4} \\
\text { Total No. of affirmative answer: } 9 \\
\text { Total No. of negative answer: } 15 \\
\text { Total No. of qualitative answer: } 1\end{array}$} \\
\hline & & & $\begin{array}{c}\mathrm{M} \\
\mathrm{A}\end{array}$ & NA & \\
\hline Judges & 2 & 6 & 0 & 0 & $M A=$ Mixed Answer $/ N A=$ Not Answered \\
\hline $\begin{array}{l}\text { Public } \\
\text { Prosecuto } \\
\text { rs }\end{array}$ & 4 & 5 & 0 & 0 & \\
\hline $\begin{array}{l}\text { Defense } \\
\text { Lawyers }\end{array}$ & 3 & 4 & 0 & 1 & \\
\hline
\end{tabular}

Qualitative Data Table on Hypothesis No. 5

\begin{tabular}{|c|c|}
\hline Categories of Participants & $\begin{array}{l}\text { Summary of qualitative answers on Hypothesis } \\
\text { No. 1 }\end{array}$ \\
\hline Judges, Public Prosecutors and Lawyers & $\begin{array}{r}\text { Not that much technicalities, people now } \\
\text { understand the laws or at least their } \\
\text { lawyers explain the provisions to them }\end{array}$ \\
$\begin{array}{l}\text { 2. } \begin{array}{l}\text { However, some people still do not } \\
\text { understand and often their lawyers take the } \\
\text { undue advantage to make more money by } \\
\text { prolonging the proceeding unnecessarily }\end{array} \\
\text { 3. } \begin{array}{l}\text { Not that much incidence of transfer of } \\
\text { cases from one Court to another }\end{array} \\
\text { 4. The problem can be overcome if the }\end{array}$ \\
\hline
\end{tabular}




\begin{tabular}{|l|l|}
\hline & $\begin{array}{l}\text { judges apply their judicial mind in } \\
\text { interpreting and applying the Act. }\end{array}$ \\
\hline
\end{tabular}

\section{Finding on Hypothesis 5}

The quantitative data informs that among 24 participants, only 9 believe that technicalities of the Nari-o-Sishu Nirjatan Daman Ain 2000 and other legislation are one of the reasons behind low conviction rate. From the qualitative data it is found that such technicalities of law have very minor contribution to blame as the potential reasons for the low conviction rate. Taking this into account, while finding out a solution to this problem, the qualitative part of the interview advocates for the application of judicial mind by the trial court in interpreting and applying the 2000 Act.

\section{Hypothesis 6}

Insufficient police investigation is a reason behind the low conviction rate in the VAW cases.

\section{Question asked:}

(i) In your opinion, do the police investigate the VAW cases satisfactorily?

\section{Quantitative Data Table on Hypothesis No. 6}

\begin{tabular}{|c|c|c|c|c|}
\hline \multirow{2}{*}{$\begin{array}{l}\text { Categorie } \\
\text { s of } \\
\text { participa } \\
\text { nts } \\
\text { interview } \\
\text { ed }\end{array}$} & \multirow[t]{2}{*}{$\begin{array}{l}\text { Affirmat } \\
\text { ive } \\
\text { answers }\end{array}$} & \multirow[t]{2}{*}{$\begin{array}{l}\text { Negativ } \\
\mathrm{e} \\
\text { answers }\end{array}$} & \multicolumn{2}{|c|}{$\begin{array}{c}\text { Qualitati } \\
\text { ve } \\
\text { answers }\end{array}$} \\
\hline & & & $\begin{array}{c}\mathrm{M} \\
\mathrm{A}\end{array}$ & NA \\
\hline Judges & 5 & 3 & 0 & 0 \\
\hline $\begin{array}{l}\text { Public } \\
\text { Prosecuto } \\
\text { rs }\end{array}$ & 7 & 2 & 0 & 0 \\
\hline $\begin{array}{l}\text { Defense } \\
\text { Lawyers }\end{array}$ & 4 & 3 & 0 & 0 \\
\hline
\end{tabular}

Total No. of participants interviewed: 24

Total No. of affirmative answer: 16

Total No. of negative answer: 8

Total No. of qualitative answer: 0

$M A=$ Mixed Answer $/ N A=$ Not Answered 
Qualitative Data Table on Hypothesis No. 6

\begin{tabular}{|c|c|}
\hline Categories of Participants & $\begin{array}{l}\text { Summary of qualitative answers on Hypothesis } \\
\text { No. } 1\end{array}$ \\
\hline Judges, Public Prosecutors and Lawyers & $\begin{array}{l}\text { 1. Police do the most damage to VAW cases } \\
\text { 2. They do not cooperate with the PP or with } \\
\text { the victim at all } \\
\text { 3. They file reports on a whim without even } \\
\text { properly investigating the crime scene } \\
\text { 4. They tend to file reports in favor of those } \\
\text { who pay them good money } \\
\text { 5. However, it always depends on the person } \\
\text { he is; if he is good then corruption does } \\
\text { not occur } \\
\text { 6. PPs do not get any coordination from the } \\
\text { Police } \\
\text { 7. Sometimes even the victims get harassed } \\
\text { by the Police } \\
\text { 8. Investigating Officer (IO) often does not } \\
\text { appear before the Court } \\
\text { 9. They cannot be found in a timely manner } \\
\text { and even if they show up, they show up } \\
\text { late } \\
\text { 10. Often they provide false and fabricated } \\
\text { reports }\end{array}$ \\
\hline
\end{tabular}

\section{Finding on Hypothesis 6}

According to the quantitative data, majority (16 out of 24) of the participants have considered inadequate police investigation as a reason that leads to negatively affect the conviction order of the court. During the qualitative interview, some of the participants have stated that in the VAW cases police does the most damages. This occurs because of their non-cooperation with the PPs and the victims, filing of false charge without proper investigation and non-appearance of the Investigation Officer at the court during trial. Corruption and bribery have been identified as the contributing factors behind. 


\section{Hypothesis 7}

Out of court settlement is a reason for low conviction rate.

\section{Question asked:}

(i) Are there incidents of 'out of court settlement' in the VAW cases?

\section{Quantitative Data Table on Hypothesis No. 7}

\begin{tabular}{|c|c|c|c|c|c|}
\hline \multirow{2}{*}{$\begin{array}{l}\text { Categorie } \\
\text { s of } \\
\text { participa } \\
\text { nts } \\
\text { interview } \\
\text { ed }\end{array}$} & \multirow[t]{2}{*}{$\begin{array}{l}\text { Affirmat } \\
\text { ive } \\
\text { answers }\end{array}$} & \multirow[t]{2}{*}{$\begin{array}{l}\text { Negativ } \\
\text { e } \\
\text { answers }\end{array}$} & \multicolumn{2}{|c|}{$\begin{array}{l}\text { Qualitati } \\
\text { ve } \\
\text { answers }\end{array}$} & \multirow{2}{*}{$\begin{array}{l}\text { Total No. of participants interviewed: } 24 \\
\text { Total No. of affirmative answer: } 19 \\
\text { Total No. of negative answer: } 3 \\
\text { Total No. of qualitative answer: } 2\end{array}$} \\
\hline & & & $\begin{array}{l}\text { M } \\
\text { A }\end{array}$ & NA & \\
\hline Judges & 6 & 0 & 1 & 1 & $\longrightarrow \quad M A=$ Mixed Answer $/ \mathrm{NA}=$ Not Answered \\
\hline $\begin{array}{l}\text { Public } \\
\text { Prosecuto } \\
\text { rs }\end{array}$ & 8 & 1 & 0 & 0 & \\
\hline $\begin{array}{l}\text { Defense } \\
\text { Lawyers }\end{array}$ & 5 & 2 & 0 & 0 & \\
\hline
\end{tabular}

Qualitative Data Table on Hypothesis No. 7

\begin{tabular}{|c|l|}
\hline Categories of Participants & $\begin{array}{l}\text { Summary of qualitative answers on Hypothesis } \\
\text { No. 1 }\end{array}$ \\
\hline Judges, Public Prosecutors and Lawyers & $\begin{array}{l}\text { 1. No provision for out of court settlement. } \\
\text { 2. If the victim (girl) belongs to a reputed } \\
\text { family, often they hesitate to come } \\
\text { forward with a case due to social prestige } \\
\text { hence out of Court settlement occurs }\end{array}$ \\
& $\begin{array}{l}\text { 3. Threat might play a factor but not always } \\
\text { 4. Monetary compensation is a factor. }\end{array}$ \\
5. Social barrier play a major role in out of \\
Court settlement \\
6. Sometimes the victims file false cases to \\
harass the husband in which case out of \\
Court settlement occurs quite often \\
7. In case of lengthy proceedings, the victim
\end{tabular}


gets reluctant to proceed with her case so she agrees to out of Court settlement

\section{Finding on Hypothesis 7}

The quantitative data reveals that out of court settlement is a crucial reason for low conviction rate in the VAW cases. 19 out of 24 participants have supported this proposition. The quantitative data points out as to why the parties to the VAW cases opt for out of court settlement. Out of court settlement occurs mainly due to threat, social barrier and sometimes the victim is not willing to continue the lengthy procedure of trial. Besides, as most of the victims before the Nari-o-Sishu Tribunal are poor, monetary gratifications from the accused act as a reason for out of court settlement. Most of the interviewees have stated that although there is no provision for out of court settlement in the 2000 Act, judges allow it as the least worst option when in a case the victim herself is unwilling to continue the case.

\section{Hypothesis 8}

Backlog of cases is a reason for low conviction rate.

\section{Question asked:}

(i) Do you think case backlog is responsible for low conviction rate in VAW cases?

Quantitative Data Table on Hypothesis No. 8

\begin{tabular}{|l|l|l|l|l|}
\hline Categorie & Affirmat & Negativ & \multicolumn{2}{|c|}{ Other } \\
$\begin{array}{c}\text { s of } \\
\text { participa } \\
\text { nts } \\
\text { answers }\end{array}$ & $\begin{array}{c}\text { e } \\
\text { answers } \\
\text { ed }\end{array}$ & & M & NA \\
\cline { 4 - 6 } & & A & \\
\hline Judges & 4 & 5 & 0 & 0 \\
\hline $\begin{array}{l}\text { Public } \\
\text { Prosecuto } \\
\text { rs }\end{array}$ & 4 & 4 & 0 & 1 \\
\hline $\begin{array}{l}\text { Defense } \\
\text { Lawyers }\end{array}$ & 4 & 2 & 0 & 0 \\
\hline
\end{tabular}

Total No. of participants interviewed: 24

Total No. of affirmative answer: 12

Total No. of negative answer: 11

Total No. of qualitative answer: 1

$M A=$ Mixed Answer $/ N A=$ Not Answered 


\section{Qualitative Data Table on Hypothesis No. 8}

\begin{tabular}{|l|l|}
\hline Categories of Participants & $\begin{array}{l}\text { Summary of qualitative answers on Hypothesis } \\
\text { No. 1 }\end{array}$ \\
\hline Judges, Public Prosecutors and Lawyers & $\begin{array}{l}\text { 1. Heavy workload of the judge. } \\
\text { 2. Non-appearance of the witness. } \\
\text { 3. Backlog of cases is a reason for delay } \\
\text { in trial. }\end{array}$ \\
$\begin{array}{l}\text { 4. Coordination among the justice sector } \\
\text { agencies should be enhanced. }\end{array}$ \\
$\begin{array}{l}\text { 5ore Nari- } o \text {-Sishu Tribunal can be } \\
\text { established. Judges should be appointed } \\
\text { at the tribunal where there is no judge. }\end{array}$ \\
\hline
\end{tabular}

\section{Finding on Hypothesis 8}

As to the identification of case backlog as a reason for low conviction rate, 12 out of 24 participants have answered affirmatively while 11 participants have mentioned it as not a reason behind low conviction rate. The qualitative data shows that case backlog may occur due to huge workload of the judge and non-appearance of witnesses. As the solution to this problem, the interviewees' contended for better coordination among the justice sector agencies, establishment of more Nari-o-Sishu Tribunals and appointment of judge at the tribunal where there is no judge. 
Identifying the most significant reasons behind low conviction rate in the VAW cases:

Table: Reasons behind low conviction rate in the VAW cases

\begin{tabular}{|c|c|c|c|c|}
\hline Reasons & Judges & $\begin{array}{l}\text { Public } \\
\text { Prosecutors }\end{array}$ & $\begin{array}{l}\text { Defense } \\
\text { Lawyers }\end{array}$ & Sub-total \\
\hline Filing of false cases & 8 & 6 & 7 & 21 \\
\hline Lack of evidence & 6 & 7 & 6 & 19 \\
\hline $\begin{array}{l}\text { Out of court } \\
\text { settlement }\end{array}$ & 6 & 8 & 5 & 19 \\
\hline $\begin{array}{l}\text { Weak Police } \\
\text { Investigation }\end{array}$ & 5 & 7 & 4 & 16 \\
\hline Case backlog & 4 & 4 & 4 & 12 \\
\hline Technicalities of Law & 2 & 4 & 3 & 9 \\
\hline $\begin{array}{l}\text { Dissatisfactory role } \\
\text { of Prosecution } \\
\text { lawyers }\end{array}$ & 2 & 4 & 1 & 7 \\
\hline $\begin{array}{l}\text { Harshness of } \\
\text { punishment under the } \\
2000 \text { Act }\end{array}$ & 2 & 2 & 2 & 6 \\
\hline
\end{tabular}




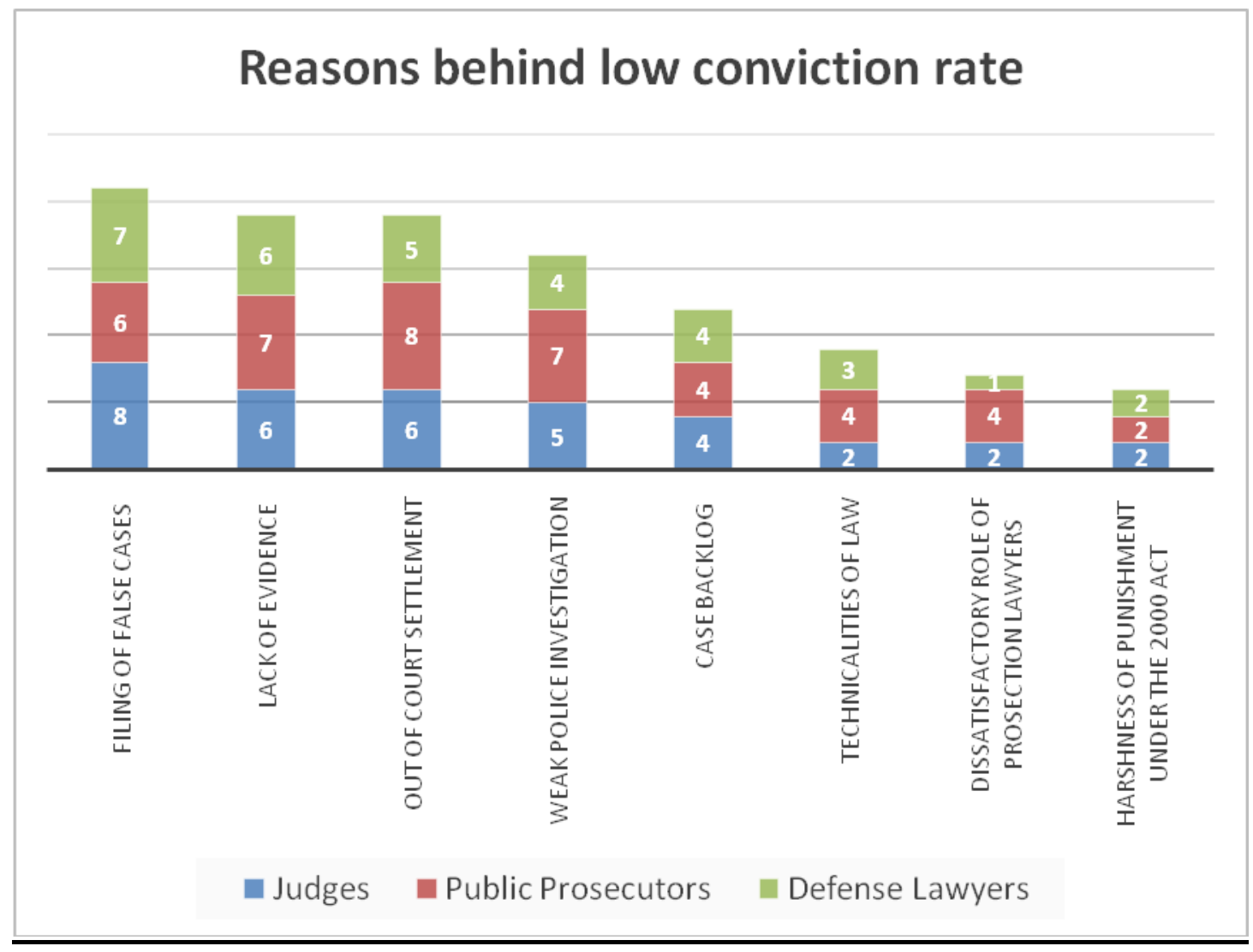

The table and the bar chart above clearly show the reasons and their contribution behind low conviction rate in the VAW cases under the Nari-o-Sishu Nirjatan Daman Ain 2000 as mentioned by the justice sector agencies and elaborately discussed in the above part of discussion. It is evident that the most significant reason behind low conviction rate is filing of false cases as 21 participants have given affirmative answer. Lack of evidence and out of court settlement are two other reasons which each with 19 participants' support have become the $2^{\text {nd }}$ reason behind low conviction. The $3^{\text {rd }}$ reason that is responsible for low conviction rate is weak police investigation. 16 out of 24 participants have pointed out this. They next reasons are, case backlog, technicalities of law, dissatisfactory role of prosecution lawyers and harshness of punishment under the 2000 Act as have been stated respectively by 12, 9, 7 and 6 participants.

\subsubsection{ANALYSIS OF THE JUDGEMENTS OF THE SUPREME COURT AND THE CASE STUDIES FROM THE TRIAL COURT:}

From an exploration of all the Supreme Court's judgments in Nari-o-Sishu cases as reported in the BLC, BLD, BLT, DLR and MLR from 2000 to 2013, it is found that except a very few instances, the Appellate Division and the High Court Division set aside the conviction order of 
the trial court. By analyzing the judgments several reasons have been identified that are responsible for low conviction rate. They are, lack of proper and adequate evidence, filing of false cases, harshness of law and non-application of judicial mind by the trial court which is exhibited though impropriety, legal infirmity, and lack of sound reasoning in the trial court's decision, excessive use of jurisdiction by the trail court, framing of wrong charge by the Tribunal and inappropriate procedure of trial.

\section{LACK OF PROPOER AND ADEQAUTE EVIDENCE:}

During the field visits at the Tribunals, lack of proper and adequate evidence has been identified as the $2^{\text {nd }}$ obvious reason for low conviction rate in the VAW cases. In many instances also, the Appellate Division or the High Court Division has set aside the conviction order for lack of evidence. A mention to these cases are significant to show the gross error of the trial court in making the conviction order at one hand and dismissal of that conviction order by the Higher Court for lack of evidence at the other.

In Md Morshed@Morshed@Md Morshed Alamv The State ${ }^{107}$, the Appellate Division dismissed the conviction order and granted bail to the appellant-petitioner due to lack of proper evidence. In that case it was found that the trial court while convicting the appellant-petitioner solely relied on the statement of the victim who was raped. But, Appellate Division observed that reliance on the evidences of a deaf and dumb victim is dangerous and as such conviction should not be based on the evidence of such witness.

In Zitu Ahsan vs. State ${ }^{108}$, the HCD allowed an appeal setting aside the conviction and sentence given by the Narayanganj Nari-o-Shishu Trigunal on 10/08/2006 u/s 9(1) of the Nari-o-Shishu Nirjatan Daman Ain 2000. The conviction was set aside by the HCD on the ground that no sign of violence was found in the medical report.

In Anwar Hossain vs State ${ }^{109}$, the conviction and sentence imposed on the accused appellant by the trial court was also set aside by the HCD because there was no sufficient evidence of the woman being taken away forcibly for the purpose of intercourse. The statements of the prosecutrix could not be corroborated by other witnesses in material points.

In Kamal Hossain vs. State ${ }^{110}$, the conviction and sentence were passed by the Nari-o-Shishu Nirjatan Daman Tribunal Natore u/s 9(1) of the Nari-o-Shishu Nirjatan Daman Ain 2000. The fact was that, the accused used to have intercourse with the victim giving assurance of her marriage. The victim became pregnant and on the denial of the accused to marry her, filed the instant case. The medical report stated that there was no mark of violence and sign of recent rape

\footnotetext{
107 (2001) 21 BLD (HCD) (2001) 350

108 (2007) 59 DLR (HCD) 528.

109 (2009) 61 DLR (HCD) 671

${ }^{110}$ (2009) 61 DLR (HCD) 505
} 
on the victim. Based on the medical report, the HCD presumed implied consent on the part of the victim and set aside the conviction.

In State vs. Sadequl Islam ${ }^{111}$, lack of evidence contributed in setting aside of the conviction. The Appellate Division observed that the charge was initially framed against the accused u/s 11(ka) and 11(ka)/30 of the Nari-o-Shishu Nirjatan Daman Ain, 2000. The Prosecution case was about killing of the victim in the demand of dowry. Defense case was that, the victim committed suicide out of frustration. Conviction and sentence passed by the Trial Court were kept intact by the HCD. The AD, however, set aside the conviction and sentence with the observation that, "it appears that the prosecution failed to prove the demand of dowry and could not prove the presence of Sadequl, the accused in the house during occurrence."

Rehana Begum vs. State ${ }^{112}$ is an interesting case where the accused persons although were not convicted for lack of evidence at the trial court but subsequently they met with the order of conviction in the High Court Division. In this case, the victim committed suicide after a gang rape. The accused persons were sentenced with life imprisonment u/s 9(3)/30 of the Nari-oShishu Nirjatan Daman Ain 2000. Witness statements were consistent. In the trial court, the medical evidence was insufficient as medical examination was conducted after the victim took bath. The HCD held that the accused persons were guilty and confirmed the conviction.

In Mehedi Hasan $v$ State $^{113}$ the appeal was filed against the judgement passed by the Nari-oSishu Tribunal of Kustia that convicted the accused with rigorous imprisonment for 14 years and a fine of Tk. 1,000/- and in default 2 (two) months imprisonment more. The High Court Division questioned the authenticity of the doctor's report and opinion as to the age of the victim. The Court observed that the way the victim should be examined was not done duly. Age is always dependent on the growth and development of human body and therefore a male or female of 18 years can be found as 15 or 16 due to lack of growth or else can be found as 19 or 20 due to puberty occurring earlier than usual. As a result, the appeal was allowed and the impugned judgement convicting the accused appellant was set aside.

The case of Kazi Nurun Nabi Parag $v$ State $^{114}$ is important to demonstrate how lack of adequate and proper evidence is related to the weak effort of the public prosecutors. In this case the appeal was preferred against the judgement passed under ss. $7 \& 9$ (1) by the Nari-o-Sishu Tribunal of Satkhira. The High Court Division contended that no FIR that named the eye witnesses was brought to prove the allegation of kidnapping and no police personnel who recovered the victim was placed before the Court to prove the said recovery and there was no evidence about the commission of rape of the victim. Therefore, the HCD was observed that the prosecution had

111 (2011) 63 DLR (AD).

112 (2011) 63 DLR (HCD) 548

113 (2012) 17 BLC (HCD) 436

114 (2011) 19 BLT (HCD) 205 
miserably failed to prove the charge levelled against the appellants in any way and the Trial Court convicted the appellants on mere surmises and conjectures and thus the impugned judgement and order of conviction was liable to be set aside.

All the justice sector agencies have pointed out that such lack of proper and adequate evidence mainly relates to the unavailability of medical report, especially in rape cases and delay in examination of witness. Delay in examination of witness takes the case against the prosecution as it potentially declines the pros and cons of the incident from the memory of the witness. ${ }^{115}$ The reasons behind the inordinate delay to examine witnesses that have been come out during the judges, PPs and DLs of the Nari-o-Sishu Tribunals are mainly three. Firstly, delay has been caused during the time of statement of the investigation officer and medical officer. In many instances, because of transferring from one place to another it becomes difficult for them to appear before the tribunal. Secondly, particularly the judges, PPs and DLs of the Nari-o-Sishu Tribunals at Dhaka have stated that as constantly people who do not have a permanent place to live at Dhaka shift from one place to another, it becomes difficult to trace the whereabouts of the witness. Thirdly, adjournment of court proceeding which is another reason for delay. In most of the cases it occurs due to the heavy workload of the judges or the absence of witness. In this regard, case backlog that contributes to heavy workload may negatively affect the prosecution case.

\section{NON-APPLICATION OF JUDICIAL MIND BY THE TRIAL COURT:}

The Supreme Court in several instances has set aside the conviction order of the trial court due to non-application of judicial mind which is expressed through impropriety, legal infirmity, and lack sound reasoning in the trial court's decision, excessive use of jurisdiction by the trail court, framing of wrong charge by the Tribunal and inappropriate procedure of trial. For example, the HCD in Alam $(M d)$ and another $v$ State ${ }^{116}$ observed that the trial court committed gross mistake in passing sentence under several penal provisions with which the convicted persons were not even charged with. The HCD observed that in the case, elements of offence as contemplated under section $9(\mathrm{ka})$ and $9(\mathrm{Ga})$ of the 2000 Act was totally absent in the charge, which was only directed against the offence of compelling the victim girl to give her consent in the marriage by abduction. So, the offence charged with was not the offence under the abovementioned sections and as such defect appeared to be substantial. The HCD also observed that the trial court had illegally relied on the statement of the victim under section 164 of the CRPC in inflicting punishment on the accused. But such a statement of witness is not legally acceptable to prove or disprove any accusation, particularly when the witness herself was available in the court.

115 Above n 44, 23.

116 (2002) 54 DLR (HCD) 298. 
In State v Bahar Mia ${ }^{117}$, the Tribunal took cognizance of an offence of causing death for dowry on the basis of police report. As the prosecution failed to prove that the death was caused for dowry, therefore, the trial court being satisfied that the death was caused by the accused, convicted the condemned prisoner for causing death under section 302 of the Penal Code. The HCD observed that although section 25 (1) of the 2000 Act provides that a Tribunal may exercise all the powers of a Sessions Judge but it was not a court of session while trying an offence under the 2000 Act. The Tribunal was constituted for trial of special offences. No power has been given to it to try any offence of the Penal Code including an offence under section 302 of the Penal Code. The High Court Division rejected the death reference and the judgment and conviction order of the trial court was aside. The HCD observed that jurisdiction over the subject matter is a condition precedent to the acquisition authority over parties and a judgement without jurisdiction is absolutely null and void. Interestingly, the HCD observed that “ ...[W]e have been noticing huge number of cases where the Nari-o-Sishu Nirjatan Daman Tribunals have been convicting accused persons under the 2000 Act, but on appeal by the convicts, this Court finds that the offences do not attract the said Act and the trials have been without jurisdiction...[T] his defects are detected at the appellate stage. This could have been avoided if the Tribunals apply their judicial mind at the time of taking cognizance of an offence...". On similar note, the case of State v Md. Akinur Rahman ${ }^{118}$ made a significant observation. The HCD stated that the overnight establishment of NOSNDTs all over the country and empowerment of the Judges who did not have any practical experience in holding trial involving capital sentence and the vesting of power of dealing with those types of cases had made an imbalance and as a result, the number of conviction and imposition of death sentences has increased. The Courts must be careful in dealing with the cases under the NOSNDA. This Court also feels cautious in passing the judgement in view that, justice should not only be done but it should also appear to have been done.

In Abul Kalam Azad vs. State ${ }^{119}$, conviction could not sustain for being based on inappropriate section of law. The provisions of the Nari-o-Shishu Nirjatan Daman Ain should be consistent with the Penal Code. Technicalities of law and lack of evidence was involved. The Appellate Division set aside the HCD's Judgment accepting the Death Reference arising out of the conviction given by the Nari-o-Shishu Nirjatan Daman Adalat, Narayanganj u/s 10 of the Nario-Shishu Nirjatan Daman (Bishesh Bidhan) Ain 1995 for death in demand of dowry. The AD held that the case should have been tried by the Sessions Court u/s 302 of the Penal Code. The problem with the conviction was insufficient evidence to prove the demand of dowry. Prosecution case in short was that, while the victim was staying with her husband, at one

\footnotetext{
117 (2004) 56 DLR (HCD) 454.

118 (2011) 19 BLT (HCD) 406

119 (2006) 58 DLR (AD) 26.
} 
morning she was found dead with signs of injury on her body. Except the maid, all witnesses stated that they did not know anything about how the death was occurred. The maid of that house stated that the victim used to be physically abused by the inmates in the demand of dowry. Likewise, in Roni Ahmed Liton v State ${ }^{120}$ the HCD held that the trial court was ex-facie wrong in convicting and sentencing the convict appellant and by setting aside the conviction order acquitted the convict appellant. In this case, the criminal appeal was filed by the accused appellant against the judgement of the Nari-o-Sishu Tribunal, Sylhet. In an allegation of rape under section 9(1) of the 2000 Act, the Tribunal sentenced him with to suffer rigorous imprisonment for life and fine of Tk. 50,000 Tk. and in default to suffer rigorous imprisonment for 2 (two) more years. The High Court Division observed that almost all the prosecution witnesses stated that the convict-appellant and the victim who is a major voluntarily married each other and they were living together as husband and wife and a baby had been born out of their wedlock. Moreover, the victim had not been examined in this case which rendered the prosecution case doubtful. Therefore, in the facts and circumstances, the allegations do not constitute offence punishable under s. 9(1) of the Act. The appeal accordingly succeeded.

In Harabilash Mitra $v$ Sanjoy Biswas and another ${ }^{121}$, gross error of law at the Tribunal was the ground to set aside the conviction order. The HCD allowed the appeal of the accused appellant and set aside the conviction order of the trial court. The Court found that the Tribunal had exceeded its jurisdiction in allowing the investigating officer to initiate the proceedings against the informant for making false allegation against the respondent under section 17 of the Nari-oSishu Nirjatan Daman Ain, 2000. The HCD stated that "in our little experience, we see that a large number of judges of the Nari-o-Sishu Tribunal have been committing the gross error of law. They have been allowing the investigating officers to initiate the proceedings against the informant/complaint under the provision of section 17 of the Nari-o-Sishu Nirjatan Ain, 2000. Tribunal must be stopped from committing the gross mistake again and again.” [para, 22]

Hossain Md. Rajib $v$ State ${ }^{122}$ places another example that shows how the trial court did gross error of law by stepping beyond its jurisdiction. In this case, the appeal was preferred by the convict appellant challenging the judgement of the Nari-o-Sishu Tribunal of Brahmanbaria that had sentenced him under ss. 11(3) \& 30 of the Nari-o-Sishu Norjatan Daman Ain 2000. The HCD contended that the learned Judge had forgotten that she was bound to dispense justice in accordance with law and a Judge cannot be an Arbitrator while dispensing justice. The Judge had no duty to compromise any dispute between the litigant public, but the act done by the learned Judge comes under the definition of a Salishder, not under the definition of a Judge, and the

\footnotetext{
${ }^{120}$ (2009) 14 MLR (HCD) 412

121 (2012) 64 DLR (HCD) 343.

122 (2011) 19 BLT (HCD) 388
} 
same is beyond the law. As a result, the appeal was allowed and the impugned judgement was set aside.

In M. Moinul Khan vs. State ${ }^{123}$, the trial Court, Sylhet Nari-o-Shishu Nirjatan Daman Tribunal rejected the complaint about causing forcible abortion of the victim. The HCD found that the trial Court misconstrued the provisions of section 27 of the Nari-o-Shishu Nirjatan Daman Ain 2000 as the Tribunal rejected the inquiry report submitted by the Magistrate, $1^{\text {st }}$ Class and directing the Additional District Magistrate Sylhet to hold another "local inquiry" for the $2^{\text {nd }}$ time. The HCD held that the Nari-o-Shishu Nirjatan Daman Ain 2000 does not keep provision for any such $2^{\text {nd }}$ time inquiry and the $1^{\text {st }}$ inquiry report in which important witness statements were recorded should have been taken into consideration.

In Sarder Lutfur Rahman v State ${ }^{124}$, a rule was issued calling upon the opposite party to show cause as to why the impugned judgement should not be set aside and/or pass such other or further order or orders as to this Court may deem fit and proper. The contention of the High Court Division was that the victim girl could not be more than 16 years of age and the Court's opinion had been corroborated by the registration card and birth certificate. It is also a well settled principle of law that birth certificate and school certificate will prevail over the medical certificate. On the issue of custody of the victim girl, the HCD felt sorry to observe that the learned Tribunal acted illegally in giving the girl in jimma of her lawyer when the matter was pending before the HCD. The Court also found that there was an unseen influential hand that played a vital role in doing all the misdeeds, e.g. even before the acceptance of police report, certified copies of police report had been supplied to the accused party. As a result, the appeal was allowed and the impugned judgement was set aside.

In Amin Uddin (Md) vs. State, the conviction could not sustain as it was based on inappropriate procedure of trial. In this case, the Nari-o-Shishu Nirjatan Daman Tribunal of Brahmanbaria directly took cognizance of an offence on the basis of a complaint and convicted the accused. The HCD observed that the provision for the Police report under section 27(1) of the Nari-oShishu Nirjatan Daman Ain 2000 required the Tribunals not to take direct cognizance against any accused. Section 173 of the Code of Criminal Procedure should have been applied. The Police report must be submitted by one Police Officer not below the rank of sub-inspector of Police. Therefore, the HCD quashed the conviction given by the trial Court u/s 9(1) of the Nario-Shishu Nirjatan Daman Ain 2000 directing to send the matter to the concerned Magistrate to take cognizance. The Brahmanbaria Tribunal was directed to send the complaint of the CR Case to Thana to be treated as first information report as the Police report is to be submitted u/s 173 of the Code of Criminal Procedure.

\footnotetext{
123 (2006) 58 DLR, 253.

124 (2011) 19 BLT (HCD) 280
} 
In MM Ishak $v$ State and another ${ }^{125}$, the High Court Division quashed the pending case of the Nari-o-Sishu Nirjatan Daman Tribunal-4, Dhaka due to technicalities of law to stop the abuse of justice. The Court observed vague and unspecific allegation of offence as torture does not mean causing hurt. Thus the allegation of torture in the FIR did not attract an offence under section 11(Kha) of the 2000 Act. There was no allegation for causing hurt for dowry. So, the allegation made in the FIR, even was taken as true, did not constitute an offence punishable under section 11 (Kha) or 11 (Kha)/30 of the Act. In Golam Ahmed $v$ State ${ }^{126}$, the HCD allowed the Appeal of the accused-appellant against the order of the trial court for the offence of rape and he was discharged. The Court observed that the manner of occurrence as alleged in the FIR was preposterous and suffered from infirmity and improbability. It was admitted that they lived together as husband and wife for six years. Sexual intercourse was not an act of the day, but for six years. Such act did not constitute an offence of rape under section 9(1) of the Act. The Tribunal wrongly framed the charge under section 9(1) of the 2000 Act against the accusedappellant, who ought to have been discharged. The appeal in Sirajul Islam v State $^{127}$ was filed by the complainant-appellant against the judgement passed by the Nari-o-Sishu Tribunal of Habiganj rejecting the Naraji petition and discharging the accused-respondent. The High Court Division contended that the expression 'any person' in s. 27(1ka)(ka) does not include any 'police officer' but it includes any public officer or any private individual or any other responsible person of the society upon whom the Tribunal may have confidence to get the enquiry conducted in respect of the complaint lodged before the Tribunal and submit report within seven working days. But these proceedings were not properly maintained during trial and hence the appeal was allowed and the impugned judgement was set aside.

The High Court Division in Uzzal alias Elias Hossain vs. State ${ }^{128}$, set aside the conviction order due to misconstruction of law and error made by the trial court in taking evidence. In this case, the HCD rejected a death reference out of the conviction and sentence passed by the Rajshahi Nari-o-Shishu Nirjatan Daman Tribunal u/s 9(2) of the Nari-o-Shishu Nirjatan Daman Bishesh Ain 1995 for death of victim after rape. Though the evidence was enough to prove rape, there was lack of evidence to prove the death of victim due to rape. The HCD held that, the conviction should have been under section 9(1) of the Act. The HCD also held that doctor's report and post mortem report was not substantive evidence but corroborative evidence only. In another case ${ }^{129}$ the HCD rejected the death reference given under section 12 of the Nari-o-Shishu Bishesh Bidhan Ain 1995 with an observation that the sentence was wrongly given under section 12

\footnotetext{
125 (2004) 56 DLR (HCD) 516.

126 (2012) 64 DLR (HCD) 93.

127 (2012) 17 BLC (HCD) 740.

128 (2007) 59 DLR(HCD) 505.

${ }^{129}$ State vs. Md Rafique (2009) 61 DLR (HCD) 158.
} 
while the appropriate section would be section 8 which does not allow death sentence for the designated offence. In Sree Pintoo Pal v State ${ }^{130}$ the conviction order passed by the trial court was also held by the Appellate Court, to be based on misreading and non-reading of evidence which had materially affected the merit of the case and as such the impugned judgement and order was liable to be set aside. Md. Abdul Hashem $v$ State ${ }^{131}$ is another case where a rule was issued the Appellate Court by calling upon the opposite party to show cause as to why the conviction order passed by the Nari-o-Sishu Tribunal-1 of Dhaka should not be set aside. The Court held that the Tribunal did not at all consider the attending circumstances, as revealed in the cross-examination by the defence, inasmuch as belated disclosure of fact of rape and belated examination of witnesses by the IO resulting the prosecution case unbelievable. By convicting the accused, therefore, the Tribunal caused miscarriage of justice. The Court further observed that judgement of conviction or acquittal cannot be passed or recorded on hypothesis rather it must be based on evidence of unimpeachable character, which were very much absent in this case. The Court then made the rule absolute and set aside the order of conviction.

Excessive use of jurisdiction by the trail court is another important factor which has been taken by the higher judiciary to set aside the conviction order of the trial court. In Nurul Haq (Md) $v$ State $^{132}$ the HCD allowed an appeal against the order that directed the Magistrate, Habigonj to file a case under section 17(1) of the Nari-o-Sishu Nirjatan Daman Ain 2000 against the appellant, informant of the case. The HCD observed the limit of jurisdiction of the trial court and stated that the said Act does not empower the tribunal to take cognizance against any person who has filed a false case or a complaint or got such a case or complaint filed by any other person. Also the tribunal has no authority to direct the Magistrate or any other person to file such complaint to enable it to take cognizance. In Mozam vs. State ${ }^{133}$, the HCD ordered for the retrial of case as the Nari-o-Shishu Nirjatan Daman Adalat of Jessore passed conviction u/s 4(c)/ 9 of the Cruelty to Woman Ordinance 1983 of which the Tribunal did not have jurisdiction. This case is also significant to show legislative inconsistencies affect the jurisdictional dilemma before the trial court. Similarly, in the death reference case, State v Md. Atiqur Rahman ${ }^{134}$, the High Court Division contended that the offence of culpable homicide punishable under the Penal Code is cognizable by the Magistrate but he did not take cognizance of such case. The offence allegedly committed was not triable by the Tribunal. Jurisdiction of a Court goes to the very root of a matter brought before it and if the Court has no jurisdiction then everything shall fall through. Therefore, this entire proceeding was vitiated due to lack of jurisdiction and the evidence

\footnotetext{
${ }^{130}$ (2010) 30 BLD (HCD) 220

131 (2011) 31 BLD (HCD) 427

132 (2003) 55 DLR (HCD) 588.

133 (2007) 59 DLR (HCD) 276

134 (2012) 17 BLC (HCD) 630
} 
recorded by the Tribunal was without jurisdiction. Hence, this death reference was rejected and the appeal was allowed.

\section{HARSHNESS OF LAW:}

By referring the Indian context, it is noted that harsher laws have created negative reaction among the judiciary because these provisions stand in the way of legal reform and liberal interpretation of fundamental rights. Judiciary to uphold the fundamental rights at its core may not go for similar trends can be noticed in the judiciary of Bangladesh as well. ${ }^{135}$ It was commented with evidence that much less than $10 \%$ of the cases that ends up with conviction under the Nari-o-Sishu Nirjatan (Bishesh Bidhan) Ain 1995 is a telling indication of the approach of the judiciary. ${ }^{136}$

Under the Nari-o-Sishu Nirjatan Daman Ain 2000, 12 offences are punishable with death sentence of which 2 are only for attempting to commit the offence. ${ }^{137}$ However, under this Act section 11(a) provides provision for mandatory death penalty for causing death for dowry. Although the compared to the earlier Nari-o-Sishu Ain 1995, the harshness is lower but, it is argued that the provision of mandatory death sentence leads to gross injustice. ${ }^{138}$ To avoid this, a conscious court being overly sensitive to its duty to protect the constitutional rights, opts for finding out alternative legislation that provides a lesser punishment. Very naturally, it affects the conviction order of the court. State vs. Anjali Debi ${ }^{139}$ is worth mentioning here where the conviction order could not sustain due to harshness of law. The judgment and order dated 15/06/2005 passed by the learned Judge of Nari-o-Shishu Nirjatan Daman Tribunal Pabna convicting the condemned prisoner under section 6 (1) of the Nari-o-Shishu Nirjatan Daman Ain, 2000 and sentencing her to death was set aside by the HCD in this case. The accused was caught by the public when she was trying to commit the offence of trafficking of the victim. The HCD held that under section 6(1), the accused should be put on trial when the victim was found to be under the custody and control of the offender from some period of time. As the accused was caught on the spot, this condition was not satisfied and the conviction was set aside by the HCD. The HCD held that the accused should get the benefit of the principles of natural justice that is, "if there are two parallel laws, harsh law should not be applied to an accused as the accused has a right for fair trial which cannot be possible under harsh law". It seems that if the 2000 Act was less harsh, conviction would be able to sustain.

${ }_{135}$ Malik, above n 3, 3.
${ }^{136}$ Ibid.
${ }^{137}$ See, section 4(1), 4(2) (a), 5(1), 5(2), 5(3), 6(1), 6(2), 8, 9(2), 11(a) and 12 of the Nari-o-Sishu Nirjatan Daman Ain 2000.

138 Tania, above n 49, 219.

139 (2009) 61 DLR 2009 (HCD)738. 
In BLAST v Bangladesh ${ }^{140}$, the petitioners argued against Section 6(2) of the Nari-o-Shishu Nirjatan (Bidesh Bidhan) Ain, 1995 on the ground that it provides mandatory death penalty with no alternative. It was also pointed out that death penalty was the only punishment available under section 6(1) of the said law as well. The petitioners also argued that Article 5 of Universal Declaration of Human Rights 1948 is also reflected in Article 35(5) of the Constitution of Bangladesh and Article 6 of International Covenant on Civil and Political Rights (ICCPR), 1996, which was ratified by Bangladesh, prohibits arbitrary deprivation of life. Article 6.5 of ICCPR provides that sentence of death shall not be imposed for crimes committed by persons below 18 years of age. By referring to due process of law of the fourteenth amendment of the American Constitution, it was submitted that the due process implies the exercise of the discretion of judge in deciding a case. Therefore, when the legislature prescribes a mandatory penalty due process is minimized. It is expected that sentencing authorities must have the discretion to consider every possible mitigating factor, rather than being limited to a specific list of factors for consideration. ${ }^{141}$ Considering inding merits in these arguments, the High Court held that Section 6(2) of the Nari-o-Shishu Nirjatan (Bishesh Bidhan) Ain 1995, now repealed, was unconstitutional.

This judgment of the HCD has been affirmed by the Appellate Division of the Supreme Court on 5 May 2015. Delivering a verdict on 12 separate appeals a four-member bench of the Appellate Division headed by Chief Justice Surendra Kumar Sinha pronounced sections 6(2), 6(3) and 6(4) of the Nari-O-Shishu Nirjatan (Bishesh Bidhan) Ain 1995 unconstitutional which provide provisions for mandatory death penalty. Section 34(2) of the Nari-o-Sishu Nirjatan Daman Ain 2000 also has been declared unconstitutional which allows the continuation of the 1995 Act in cases which are pending under the 1995 Act. As a result, death penalty or life imprisonment for killing after rape can be awarded because by amending the 1995 Act, the Act of 2000 in section 9(2) provides these two punishments. However, the grounds on which the SC delivered the verdict and its observations could not be known, as it did not release the full judgment. ${ }^{142}$

\section{FILING OF FALSE CASES:}

Although section 17 of the Nari-o-Sishu Nirjatan Daman Ain provides punishment for filling of false cases, the findings of the tribunal visits reveal that most of the cases filed under this Act are false and fabricated. These cases are filed to take revenge out of personal enmity or to satisfy proprietary interest or to get redress for other grievance against the accused. Sometimes, law enforcing agency, particularly the investigating officer is also involved in such instances. ${ }^{143}$

For example, in an appeal against the judgment of the Nari-o-Sishu Tribunal of Bagerhat, the High Court Division observed that the wife was not assaulted by the accused for dowry and as

\footnotetext{
${ }^{140}$ Writ Petition No. 8283 of 2005.

${ }^{141}$ Locket vs. Ohio (1978) 438 US 586.

${ }^{142}$ Information retrieved from <http://www.thedailystar.net/backpage/death-penalty-95-law-scrapped-80686>, last visited on 07.05.2015.

${ }^{143}$ Tania, above n 49, 234.
} 
such the allegations made in the FIR did not constitute offence punishable under s. 11(3) read with s. 30 of the Act. The charge sheet filed by the police and the facts of the case did not match, nor did the statements provided by the witnesses. As such, this appeal was partly allowed for the accused No. 1 and was partly dismissed for accused appellant No. 2. ${ }^{144}$ State $v$ Osena Begum@Babuler Ma and another is an interesting case which, however, raises alarm on one hand in respect of filing of false cases and over-sympathy of the human rights activists, low enforcing agency and court towards the victim, on the other. ${ }^{145}$ In this case, the Nari-o-Sishu Nirjatan Daman Tribunal convicted the accused (mother-in-law and husband of the victim) with death sentence solely on the basis a newspaper report. The prosecution case, initiated by a human rights organization made up a case of murdering the wife with acid by the husband and motherin-law whereas the victim died due to catching of fire while she was cooking. Even the mother and sister of the victim denied the allegation of the murder during examination at the tribunal and were declared hostile witness. When the matter went to the High Court Division, the Court while setting aside the conviction order observed that,

“ ... [W] hen a new law is made to prevent heinous crimes of new dimension, the Court is expected to be fully abreast of such law and more circumspect in its application. This does not mean that the Court should not take the pains of the victim intimately and seriously. It would definitely be sensitive but within the limits of law. Once such an offence is proved, it would not hesitate to strike like a thunder. It would be able to do so only when it can guard himself from being swayed away by any unfounded emotion and sensitivity.",146

This case clearly shows that how filling of false case leads to no-conviction and ultimately hampers the purpose of justice. Acknowledging that innocent persons are trapped with ulterior motive, in State v Abdur Rashid and others ${ }^{147}$, it was observed that the court has an arduous duty to separate innocent persons from the offenders and for this court is to deal with such cases with circumspection, scrutinize evidence and materials on record with utmost care.

\subsubsection{CASE-STUDIES FORM THE NARI-O-SISHU TRIBUANL COMILLA:}

The following brief case studies of the Trial Court's judgments show how, some of these reasons, e.g., lack of evidence, out of court settlement, filing of false case results into the order of no-conviction.

\section{Nari-o-Shishu Mamla No. 84/2011: Comilla.}

This case on sexual harassment had been logged before the court due to non-taking of the case by police. Based upon the investigation of female vice chairman of Comilla Sador (South) the

\footnotetext{
${ }^{144}$ Nakib Ashraf Ali v State (2009) 14 MLR (HCD) 286

145 Ibid.

146 (2003) 23 BLD (HCD) 336, at 339, para 46.

147 (1998) 19 BLD 307.
} 
case had been formally appeared before court under the section 10/30 of the Nari-o-Sishu Nirjatan Daman Ain 2000. But during trial, the plaintiff didn't present the required testimony and other documentary evidences in support of their complaint. They presented only one witness who was considered insufficient by the court as the witness could not confirm the involvement of the accused persons. Moreover, the plaintiff subsequently informed the court that they were not willing to continue the case. Finally, the case was dismissed.

Date of judgment: April 06, 2015.

\section{Nari-o-Shishu Mamla No. 124/2010: Comilla.}

Due to the rejection from police, the case was filed at the court. The case was on the demand of dowry and consequent physical torture by the victim's husband and in-laws. On direction of the court, after police investigation the case had been appeared before court under section 11(c)/ 30 of the Nari-o-Sishu Nirjatan Daman Ain 2000. During trail, the plaintiff didn't present sufficient witness and other essential evidences to support her complain. Moreover, at one stage of the trail, the victim formally informed the court that the complaint against husband was not rather the case was due to misunderstanding with her husband. The case was dismissed.

Date of judgment: February 08, 2015.

\section{Nari-o-Shishu mamla no. 199/2013: Comilla.}

Under section 9(4) (b) of the Nari-o-Sishu Nirjatan Daman Ain 2000 the case was logged at the tribunal. The case was on sexual harassment and attempt to rape. During trail, only two witnesses were present but evidence provided by them was regard insufficient and irrelevant by the tribunal. Moreover, the victim as PW-1 and her husband as PW-2, formally informed the court that issue of the case was not true, rather, they had been persuaded by other family members to file the case. Finally, the case was dismissed.

Date of judgment: April 06, 2015.

\section{Nari-o-Shishu Mamla No. 460/2012: Comilla.}

As a result of the rejection from police, plaintiff filed the case at the tribunal under 11(c)/30 of the Nari-o-Sishu Nirjatan Daman Ain 2000 on accusing her husband Md. Manik Miah for dowry and torture. In support of their complaint, the plaintiff presented only two witnesses but the court did not find anything truthful to go against the accused. Moreover, the plaintiff, Aklima as P.W-1 and her father as P.W.-2 formally informed the court there had nothing had happened, it was only family quarrel between husband $\&$ wife. Finally, the case was dismissed. 
Date of judgment: April 02, 2015.

\section{Nari-o-Shishu Mamla No. 394/2010: Comilla.}

The plaintiff filed the case before court under 11(c)/30 of the Nari-o-Sishu Nirjatan Daman Ain 2000 against her husband and his accomplices, for demanding dowry of BDT 200000 and torturing. In the trail the court found that the allegation against the accused was not true. The tribunal, then, acquitted the accused.

Date of judgment: April 07, 2015.

\section{Nari-o-Shishu Mamla No. 620/2013: Comilla.}

The case was filed by the victim's elder brother at the police station by accusing victim's husband and two other family members of victim's husband for demanding dowry BDT 200000 and torture. Police investigated and provided charge sheet under 11(c)/30 of Nari-o-Sishu Nirjatan Daman Ain 2000 against the accused. During trial, the tribunal found that the evidence that presented by the victim was too weak to prove the case. In addition, at one of the trial, the plaintiff party lost interest to continue the case and informed the tribunal that victim had negotiated with her husband and agreed to resume their congenial life. The tribunal then released the accused persons.

Date of judgment: April 05, 2015. 


\section{CHAPTER 6 \\ DATA ANALYSIS AND FINDINGS ON LEGISLATIVE INCONSISTENCIES IN THE VAW LEGISLATIONS}

In this part, the investigation results are presented with reference to the quantitative and qualitative data on legislative inconsistencies in the Family Courts Ordinance $1985^{148}$, the Dowry Prohibition Act $1980^{149}$, the Nari-O Shishu Nirjatan Daman Ain 2000 (The Prevention of Oppression Against Women and Children Act 2000) ${ }^{150}$ and the Domestic Violence Act $2010^{151}$. The data analysis of this chapter is further supported by a comparative analysis of the provisions of the above mentioned VAW legislations. This part is broadly organized in two sections. Firstly, section-1 presents the data collected from the field works undertaken at Dhaka, Comilla and Pabna Nari-O Shishu Nirjatan Daman Tribunals and Magistrate Courts. Then, in section-2, the work presents the comparative analysis of the legal provisions in the selected VAW legislations.

\subsection{SECTION-1: SUMMARY OF QUANTITATIVE AND QUALITATIVE DATA ON THE VAW LEGISLATIVE INCONSISTENCIES COLLECTED FROM DHAKA, COMILLA AND PABNA TRIBUNALS AND COURTS}

After the initial literature review relating to the legislative inconsistencies in the Nari-o-Shishu Nirjatan Daman Ain 2000, the Dowry Prohibition Act 1980, the Domestic Violence Act 2010 and the Family Courts Ordinance 1985, the present research could set some hypothesis to be tested by the quantitative and qualitative data planned to be collected from Dhaka, Comilla and Pabna Courts. Accordingly, the corresponding questions were set. In the course of field works, this project interviewed a total number of 24 participants consisting of Judges, Public Prosecutors and Lawyers who specially deal with the VAW Cases. During the interview, the participants have given either affirmative or negative answers at first. The participants who gave affirmative answers were then requested to explain further. These explanations are summarized in this work as qualitative answers of the participants. The related hypothesis and the data collected from quantitative and qualitative interview about legislative inconsistency in the VAW Cases are presented in this chapter as follows.

\footnotetext{
${ }^{148}$ Act No. XVIII of 1985.

149 Act No. XXXV of 1980.

${ }^{150}$ Act No. VIII of 2000.

${ }^{151}$ Act No. 58 of 2010.
} 
Hypothesis relating to the VAW legislative inconsistencies at a glance (For collecting quantitative and qualitative data from interview)

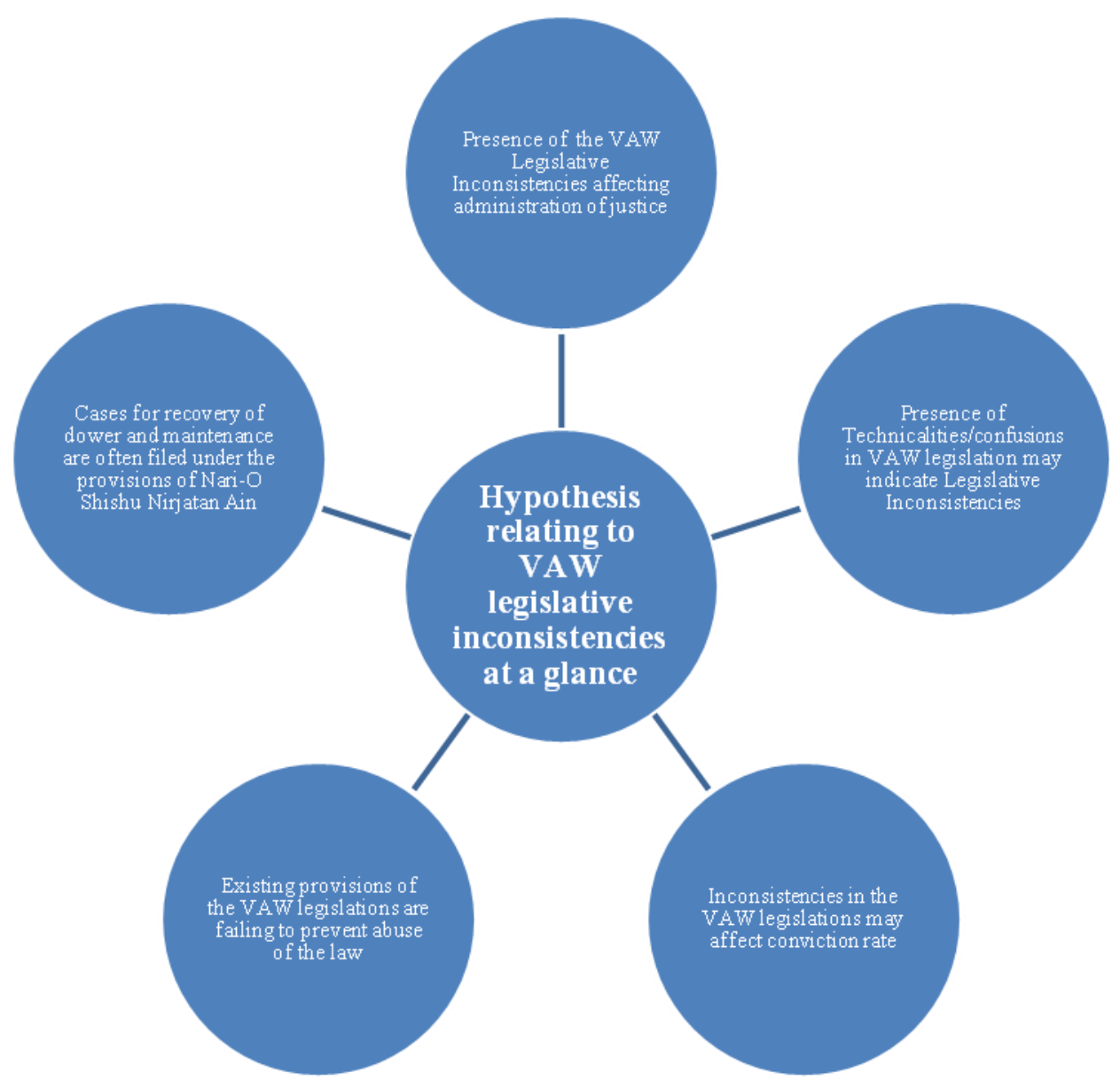

Figure: Hypothesis on the VAW legislative inconsistencies 


\section{Hypothesis No. 1:}

(i) There may be legislative inconsistencies in the VAW legislations

(ii) If there are legislative inconsistencies, it may hinder effective administration of justice

\section{Question Asked:}

Do you experience legislative inconsistencies (while administering justice/practicing law) in the VAW legislations as an interrupting factor that may prevent to ensure justice in the VAW cases?

Quantitative Data Table on Hypothesis No. 1

\begin{tabular}{|l|l|l|l|}
\hline $\begin{array}{c}\text { Categorie } \\
\text { s of } \\
\text { participa } \\
\text { nts } \\
\text { interview } \\
\text { ed }\end{array}$ & $\begin{array}{l}\text { Affirmat } \\
\text { ive } \\
\text { answers }\end{array}$ & $\begin{array}{c}\text { Negativ } \\
\text { e } \\
\text { answers }\end{array}$ & $\begin{array}{c}\text { Qualitati } \\
\text { ve } \\
\text { answers }\end{array}$ \\
\hline Judges & 3 & 4 & 3 \\
\hline $\begin{array}{l}\text { Public } \\
\text { Prosecuto } \\
\text { rs }\end{array}$ & 2 & 7 & 2 \\
\hline $\begin{array}{l}\text { Other } \\
\text { Lawyers }\end{array}$ & 3 & 4 & 3 \\
\hline
\end{tabular}

Total No. of participants interviewed: 24

Total No. of affirmative answer: 8

Total No. of negative answer: 15

Total No. of qualitative answer: 8

\section{Qualitative Data Table on Hypothesis No. 1}

\begin{tabular}{|c|c|}
\hline Categories of Participants & $\begin{array}{l}\text { Summary of qualitative answers on Hypothesis } \\
\text { No. } 1\end{array}$ \\
\hline Judges, Public Prosecutors and Lawyers & $\begin{array}{l}\text { 1. Section 11(c) of the } 2000 \text { Act dealing } \\
\text { with simple hurt for dowry should be } \\
\text { made compoundable. } \\
\text { 2. Nari-o-Shishu Nirjatan Daman } \\
\text { Tribunals should have bail granting } \\
\text { power in both the CR and GR cases at } \\
\text { any stage of investigation and trial. } \\
\text { 3. Every kind of the VAW case } \\
\text { proceedings should be brought under } \\
\text { the jurisdiction of one specific }\end{array}$ \\
\hline
\end{tabular}




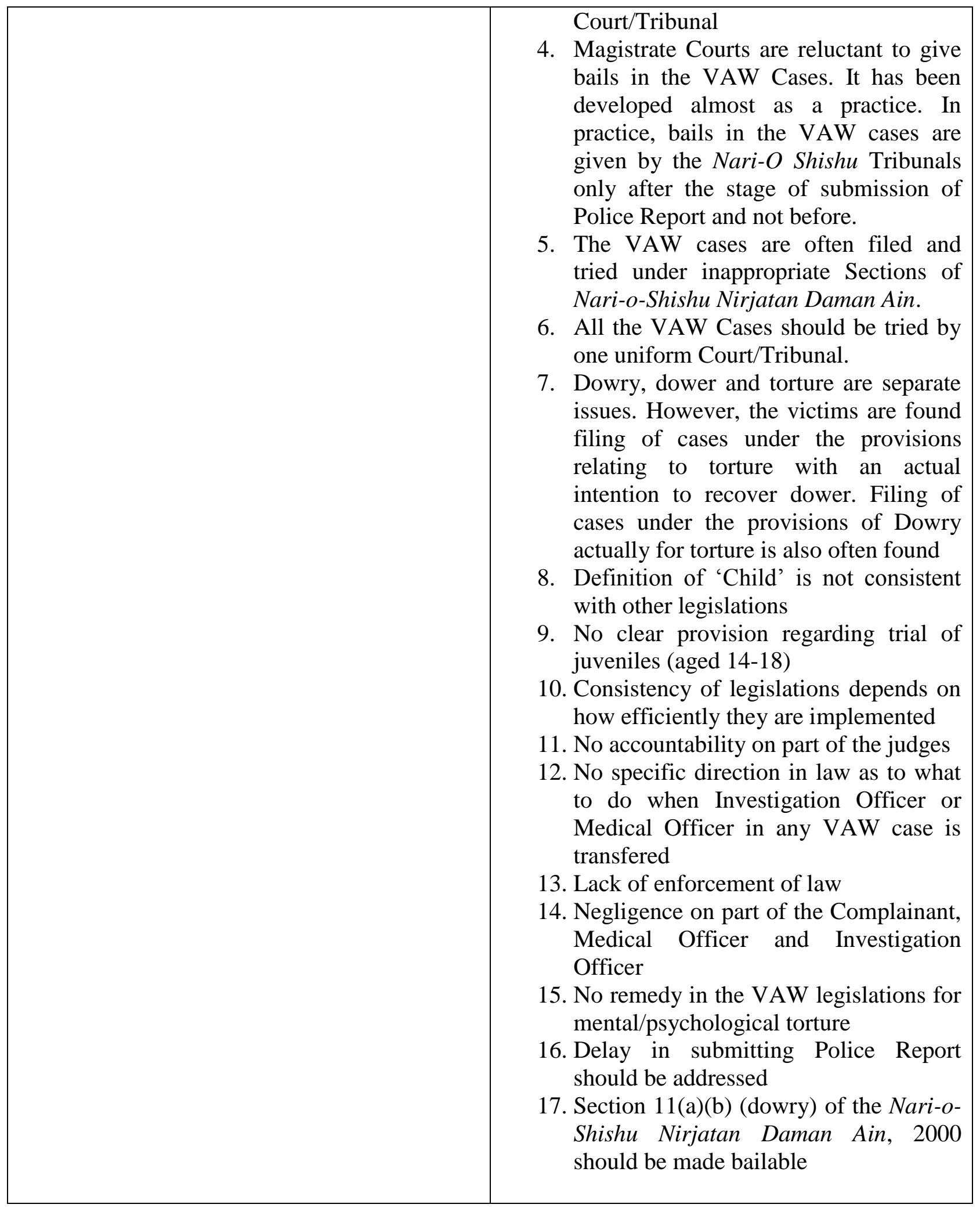




\section{Finding on Hypothesis No. 1:}

The majority interview participants have said that they do not experience legislative inconsistency in the VAW legislations. Therefore, the quantitative data rejects the hypothesis about existence of legislative inconsistencies in the VAW legislations. However, this finding of quantitative data is to be verified by the qualitative data. The qualitative data table on hypothesis No.1 shows that a number of inconsistencies have been identified by the interview participants who experience legislative inconsistencies in the VAW legislations in the course of administering justice or practicing law. The qualitative answers should be taken into consideration to make the VAW legislations more consistent.

\section{Hypothesis No. 2}

Technicalities or confusing nature of the VAW legislations may indicate legislative inconsistencies or overlapping

\section{Question Asked:}

Do you find the VAW legislations too technical or confusing to understand?

\section{Quantitative Data Table on Hypothesis No. 2}

\begin{tabular}{|l|l|l|l|}
\hline $\begin{array}{c}\text { Categorie } \\
\text { s of } \\
\text { participa } \\
\text { nts } \\
\text { interview } \\
\text { ed }\end{array}$ & $\begin{array}{c}\text { Affirmat } \\
\text { ive } \\
\text { answers }\end{array}$ & $\begin{array}{c}\text { Negativ } \\
\text { e } \\
\text { answers }\end{array}$ & $\begin{array}{c}\text { Qualitati } \\
\text { ve } \\
\text { answers }\end{array}$ \\
\hline Judges & 4 & 4 & 4 \\
\hline $\begin{array}{l}\text { Public } \\
\text { Prosecuto } \\
\text { rs }\end{array}$ & 5 & 4 & 5 \\
\hline $\begin{array}{l}\text { Other } \\
\text { Lawyers }\end{array}$ & 1 & 6 & 1 \\
\hline
\end{tabular}

Total No. of participants interviewed: 24

Total No. of affirmative answer: 10

Total No. of negative answer: 14

Total No. of qualitative answer: 10 
Qualitative Data Table on Hypothesis No. 2

\begin{tabular}{|c|c|}
\hline Categories of Participants & $\begin{array}{l}\text { Summary of qualitative answers on Hypothesis } \\
\text { No. } 2\end{array}$ \\
\hline Judges, Public Prosecutors and Lawyers & $\begin{array}{l}\text { 1. Due to legal technicalities, often access } \\
\text { to justice is hindered } \\
\text { 2. Sometimes, the Court staffs take undue } \\
\text { advantage of the technicalities and } \\
\text { abuse the process } \\
\text { 3. Most of the victims do not understand } \\
\text { the provisions, they do whatever their } \\
\text { lawyers ask them to do } \\
\text { 4. Victims are ignorant of the laws } \\
\text { 5. Most of the victims are illiterate } \\
\text { 6. Sometimes, the victim or the accused } \\
\text { is a dumb person, so s/he cannot } \\
\text { communicate properly and there is no } \\
\text { clear provision/direction to help them }\end{array}$ \\
\hline
\end{tabular}

\section{Finding on Hypothesis No. 2:}

The majority of the interview participants have responded that they do not find the VAW legislations too technical except the usual technicalities of law. However, the participants who have given qualitative answers have opined that the VAW legislations should be widely known by the common people so that they can easily take recourse of law. Creating awareness about the existing VAW legislations is recommended by the participants of the interview.

\section{Hypothesis No. 3}

Legislative inconsistencies may affect conviction rate in the VAW cases

\section{Question Asked:}

Do you find technicalities or confusing nature of the VAW legislations as one of the factors for low conviction rate in the VAW cases? 
Quantitative Data Table on Hypothesis No. 3

\begin{tabular}{|l|l|l|l|}
\hline $\begin{array}{c}\text { Categorie } \\
\text { s of } \\
\text { participa } \\
\text { nts } \\
\text { interview } \\
\text { ed }\end{array}$ & $\begin{array}{c}\text { Affirmat } \\
\text { ive } \\
\text { answers }\end{array}$ & $\begin{array}{c}\text { Negativ } \\
\text { e } \\
\text { answers }\end{array}$ & $\begin{array}{c}\text { Qualitati } \\
\text { ve } \\
\text { answers }\end{array}$ \\
\hline Judges & 2 & 6 & 2 \\
\hline $\begin{array}{l}\text { Public } \\
\text { Prosecuto } \\
\text { rs }\end{array}$ & 4 & 5 & 4 \\
\hline $\begin{array}{l}\text { Other } \\
\text { Lawyers }\end{array}$ & 3 & 4 & 3 \\
\hline
\end{tabular}

Total No. of participants interviewed: $\mathbf{2 4}$

Total No. of affirmative answer: 9

Total No. of negative answer: 15

Total No. of qualitative answer: 9

Qualitative Data Table on Hypothesis No. 3

\begin{tabular}{|c|r|}
\hline Categories of Participants & $\begin{array}{l}\text { Summary of qualitative answers on Hypothesis } \\
\text { No. } 3\end{array}$ \\
\hline Judges, Public Prosecutors and Lawyers & $\begin{array}{l}\text { 1. } \begin{array}{l}\text { Sometimes, legislative inconsistency } \\
\text { becomes a factor responsible for low } \\
\text { conviction rate when the Court staffs } \\
\text { try to abuse the process }\end{array} \\
\text { 2. } \begin{array}{l}\text { The judges and lawyers try to do their } \\
\text { best to prevent legislative inconsistency } \\
\text { to affect the conviction rate }\end{array} \\
\text { 3. The VAW legislations do not have } \\
\text { extraordinary technicalities. } \\
\text { Technicalities is a common character of } \\
\text { law } \\
\text { 4. People understand the VAW } \\
\text { legislations } \\
\text { 5. Even if not, then their lawyers explain } \\
\text { the provisions to them }\end{array}$ \\
\hline
\end{tabular}




\section{Finding on Hypothesis No. 3}

Most of the participants of the quantitative interview have confirmed that technicalities in the VAW legislations do not affect the low conviction rate in the VAW cases. However, this finding is not supported by a number of judgments given by the Supreme Court of Bangladesh discussed in the other chapters of this research. From numerous decisions of the Supreme Court, it is observed that the VAW cases are often filed and tried under inappropriate provisions of law. The convictions given under the inappropriate provisions of law cannot sustain in the Appellate Court (High Court Division of the Supreme Court of Bangladesh). Therefore, this research denies to rely on the findings of this quantitative interview without analyzing the decisions of the Supreme Court.

\section{Hypothesis No. 4}

(i) The VAW legislations may have kept open the chance of abusing law

(ii) If the VAW legislations have kept open the chance of abusing law, consistency/clarification among the VAW legislations may improve the situation

\section{Question Asked:}

Do you experience filing of the VAW Cases (for dowry/torture) under the provisions of the Nario-Shishu Nirjatan Daman Ain 2000 which should appropriately be filed before the Family Courts for dower and maintenance?

\section{Quantitative Data Table on Hypothesis No. 4}

\begin{tabular}{|l|l|l|l|}
\hline $\begin{array}{c}\text { Categorie } \\
\text { s of } \\
\text { participa } \\
\text { nts } \\
\text { interview } \\
\text { ed }\end{array}$ & $\begin{array}{c}\text { Affirmat } \\
\text { ive } \\
\text { answers }\end{array}$ & $\begin{array}{c}\text { Negativ } \\
\text { e } \\
\text { answers }\end{array}$ & $\begin{array}{c}\text { Qualitati } \\
\text { ve } \\
\text { answers }\end{array}$ \\
\hline Judges & 8 & 0 & 8 \\
\hline $\begin{array}{l}\text { Public } \\
\text { Prosecuto } \\
\text { rs }\end{array}$ & 6 & 3 & 6 \\
\hline $\begin{array}{l}\text { Other } \\
\text { Lawyers }\end{array}$ & 7 & 0 & 7 \\
\hline
\end{tabular}

Total No. of participants interviewed: 24

Total No. of affirmative answer: 21

Total No. of negative answer: 3

Total No. of qualitative answer: 21 


\section{Qualitative Data Table on Hypothesis No. 4}

\begin{tabular}{|c|c|}
\hline Categories of Participants & $\begin{array}{l}\text { Summary of qualitative answers on Hypothesis } \\
\text { No. } 4\end{array}$ \\
\hline Judges, Public Prosecutors and Lawyers & $\begin{array}{l}\text { 1. Most of the false cases are filed under } \\
\text { the dowry provisions } \\
\text { 2. Cases are sometimes filed on silly } \\
\text { reasons just to harass the accused } \\
\text { 3. Case stories do not sometimes relate to } \\
\text { the actual incidence } \\
\text { 4. False witnesses pose are often found } \\
\text { 5. Even the genuine witnesses sometimes } \\
\text { tell lies due to various reasons } \\
\text { (pressure, threat, social issues etc.) } \\
\text { 6. Most of the dowry cases turn out to be } \\
\text { false as it cannot be proved at the end } \\
\text { 7. False witness and false medical } \\
\text { evidence are noticed as well }\end{array}$ \\
\hline
\end{tabular}

\section{Finding on Hypothesis No. 4}

The VAW legislations are failing to prevent their abuse. Majority of the participants in the quantitative interview have confirmed that cases are often filed on the ground of Dowry under the Nari-o-Shishu Nirjatan Daman Ain 2000 with a real hidden intention to recover maintenance or dower. Dower and maintenance appropriately fall under the jurisdiction of the Family Courts. This issue should be addressed by the VAW legislations.

\section{Hypothesis No. 5}

Lack of good coordination among Police, Investigation Officers, Magistrates and Nari-O Shishu Nirjatan Daman Tribunals may indicate procedural consistencies in the VAW legislations

\section{Question Asked:}

Do you experience good coordination amongst Police, Investigation Officers, Magistrates and Nari-o-Shishu Nirjatan Daman Tribunals regarding the trial of the VAW cases? 


\section{Quantitative Data Table on Hypothesis No. 5}

\begin{tabular}{|l|l|l|l|}
\hline $\begin{array}{l}\text { Categorie } \\
\text { s of } \\
\text { participa } \\
\text { nts } \\
\text { interview } \\
\text { ed }\end{array}$ & $\begin{array}{l}\text { Affirmat } \\
\text { ive } \\
\text { answers }\end{array}$ & $\begin{array}{l}\text { Negativ } \\
\text { answers }\end{array}$ & $\begin{array}{l}\text { Qualitati } \\
\text { ve } \\
\text { answers }\end{array}$ \\
\hline Judges & 7 & 1 & 7 \\
\hline $\begin{array}{l}\text { Public } \\
\text { Prosecuto } \\
\text { rs }\end{array}$ & 4 & 4 & 4 \\
\hline $\begin{array}{l}\text { Other } \\
\text { Lawyers }\end{array}$ & 2 & 5 & 2 \\
\hline
\end{tabular}

Total No. of participants interviewed: $\mathbf{2 4}$

Total No. of affirmative answer: 13

Total No. of negative answer: 10

Total No. of qualitative answer: 13

\section{Qualitative Data Table on Hypothesis No. 5}

\begin{tabular}{|c|c|}
\hline Categories of Participants & $\begin{array}{l}\text { Summary of qualitative answers on Hypothesis } \\
\text { No. } 5\end{array}$ \\
\hline Judges, Public Prosecutors and Lawyers & $\begin{array}{l}\text { 1. Police gives proper report, but are } \\
\text { found to take bribe in some instances as } \\
\text { well. } \\
\text { 2. There are bribery and corruption issues } \\
\text { along with political pressure } \\
\text { sometimes, but it solely depends on the } \\
\text { officers involved } \\
\text { 3. Police files Investigation Reports } \\
\text { without taking any responsibility, they } \\
\text { do the job just for the sake of doing it } \\
\text { 4. Negligence on the part of the police is } \\
\text { often found } \\
\text { 5. Police taking bribe, do not even go to } \\
\text { the crime scene, and often files a blind } \\
\text { report } \\
\text { 6. Medical evidence from the Medical } \\
\text { Officers cannot be obtained within time } \\
\text { 7. Complicated process without any good } \\
\text { coordination among the Prosecution }\end{array}$ \\
\hline
\end{tabular}


Counsels, Police, Investigation Officers and Medical Officers

\section{Finding on Hypothesis No. 5}

13 participants in a total of 24 have said that they experience moderate coordination among Police, Medical Officers, Lawyers and Judges in the VAW cases. However, 10 Participants have said that there is a lack of reasonable coordination. The VAW legislations are silent about this. Qualitative answers show that bribes and corruption may interrupt the whole proceeding. The VAW legislations should emphasize this issue.

\subsection{SECTION-2: COMPARISION OF THE RELEVANT PROVISIONS OF THE SELECTED VAW LEGISLATIONS}

To verify and cross-check the findings of quantitative and qualitative data collected from the questionnaire based interview, this section of the work compares the relevant provisions of the selected VAW legislations to further investigate the issue of legislative inconsistency. This section is organized under three broad sub-heads. Firstly, the discussion on inter-legislation inconsistencies will compare each of the VAW legislation with the other. Secondly, the discussion on intra-legislation inconsistencies will investigate the overlapping within any single legislation (if any). The last sub-head will discuss about the inconsistency of the selected special VAW legislations with other relevant general legislations in force in Bangladesh.

\section{(I) Inter-legislative inconsistencies}

\section{(a) Inconsistencies in the respective scopes and subject matters of the VAW legislations}

A comparison of the respective scope and jurisdiction of the Nari-o-Shishu Nirjatan Daman Ain 2000, the Dowry Prohibition Act 1980, the Domestic Violence Act 2010 and the Family Court Ordinance 1985 is necessary to examine whether there is any inconsistency, contradiction or overlapping within these legislations. This comparison is particularly relevant because the ideal VAW legislations are supposed to set clear and specific goals ${ }^{152}$ to avoid inconsistency and are also supposed to be comprehensive and multidisciplinary prohibiting all forms of violence. ${ }^{153}$ If

\footnotetext{
${ }^{152}$ United Nations: Good Practices in Legislation on Violence against Women (2008) <http://www.un.org/womenwatch/daw/egm/vaw_legislation_2008/Report\%20EGMGPLVAW\%20\%28final\%2011. 11.08\%29.pdf. $>$.

${ }^{153}$ United Nations, UN Handbook for Legislation on Violence against Woman 2010 (2010)

< www.un.org/womenwatch>, last retrieved on 15 March, 2015
} 
the legislations are specific about the respective scope, subject matter and jurisdiction, the possibility of any inconsistency, contradiction or overlap also becomes minimal.

\section{(i) Nari-o-Shishu Nirjatan Daman Ain 2000 and the Dowry Prohibition Act 1980}

In the Preamble of the Nari-o-Shishu Nirjatan Daman Ain 2000, it is provided that, this law is enacted to make necessary provisions for the prevention of crimes against women and children. ${ }^{154}$ The Preamble of this legislation justifies it as "Whereas, it is proper and expedient to make provisions for the strict prevention of offences relating to women and child oppression, so the Act is enacted". ${ }^{155}$ The language of the Preamble of the Nari-o-Shishu Nirjatan Daman Ain 2000 is very general and gives an impression that all kinds of offences relating to women and children are addressed by this law. However, the law is not comprehensive. The subject matters of this legislation include the offences committed by corrosive or any other substances, ${ }^{156}$ trafficking of women and children, ${ }^{157}$ kidnapping a child or a woman, ${ }^{158}$ detaining women or children for taking ransom, ${ }^{159}$ rape or death in consequence of rape, ${ }^{160}$ sexual oppression, ${ }^{161}$ causing or attempting to cause death for dowry, ${ }^{162}$ causing simple or grievous hurt for dowry ${ }^{163}$ and impairing any limb of a child for the purpose of begging. ${ }^{164}$ Additionally this law makes the rapist liable for the maintenance of any child born in consequence of rape ${ }^{165}$ and prohibits the news media to publish acquaintance of a woman or a child oppressed. ${ }^{166}$ The jurisdiction to try the offences under this legislation is conferred to the Nari-o-Shishu Nirjatan Daman Tribunals as established $\mathrm{u} / \mathrm{s} 25$ of the Act.

The Preamble of the Dowry Prohibition Act 1980 describes itself as "an Act to prohibit the taking or giving of dowry in marriages." 167 This Act justifies itself as, "WHEREAS it is expedient to make provision to prohibit the taking or giving of dowry in marriages, it is hereby enacted as follows". ${ }^{168}$ The subject matters of this Act include penalty for giving or taking dowry, ${ }^{169}$ penalty for demanding dowry ${ }^{170}$ and invalidating any agreement for giving or taking

\footnotetext{
154 The Nari-O Shishu Nirjatan Daman Ain 2000, Act No. VIII of 2000 preamble.

${ }^{155}$ Ibid.

${ }^{156}$ Act No. VIII of $2000 \mathrm{~s} 4$.

157 Act No. VIII of 2000 ss 5-6.

158 Act No. VIII of $2000 \mathrm{~s} 7$.

${ }^{159}$ Act No. VIII of $2000 \mathrm{~s} 8$.

${ }^{160}$ Act No. VIII of $2000 \mathrm{~s} 9$.

${ }^{161}$ Act No. VIII of $2000 \mathrm{~s} 10$.

162 Act No. VIII of 2000 s 11.

163 Ibid.

${ }^{164}$ Act No. VIII of $200 \mathrm{~s} 12$.

${ }^{165}$ Act No. VIII of $2000 \mathrm{~s} 13$.

166 Act No. VIII of $2000 \mathrm{~s} 14$.

167 The Dowry Prohibition Act 1980, Act No. XXXV of 1980 preamble.

${ }^{168}$ Ibid.

${ }^{169}$ Act No. XXXV of $1980 \mathrm{~s} 3$.

${ }^{170}$ Act No. XXXV of 1980 s 4.
} 
dowry. ${ }^{171}$ This Act provides that no Court inferior to that of a magistrate of the first class shall try any offence under this Act. ${ }^{172}$ It is also a requirement that no Court shall take cognizance of any such offence except on a complaint made within one year from the date of the offence. ${ }^{173}$ Every offence under this Act is non cognizable, non-bailable and compoundable. ${ }^{174}$

The Nari-o-Shishu Nirjatan Daman Ain 2000 was enacted in 2000 after the enactment of the Dowry Prohibition Act 1980. Both the legislations deal with the offences related to dowry. To be more consistent, any single legislation should comprehensively deal with all the offences related to dowry. As dowry is one of the forms of violence against women, there is no bar to include all the dowry related offences in the Nari-o-Shishu Nirjatan Daman Ain 2000 by a legislative amendment. Since the Nari-o-Shishu Nirjatan Daman Ain 2000 establishes special Tribunals for the trial of the offences, all dowry related offences if tried by the same Tribunals, the administration of justice will be smoother.

\section{(ii)The Domestic Violence Act 2010 and the Family Courts Ordinance 1985}

The Preamble of the Domestic Violence Act 2010 justifies this legislation as follows:

"WHEREAS it is expedient and necessary as a signatory state of the United Nations Convention on the Elimination of All Forms of Discrimination against Women, 1979 and Convention on the Children's Right, 1989 and to establish equal rights for women and children guaranteed in the Constitution of the People's Republic of Bangladesh prevention of domestic violence, protection of women and children from domestic violence and for matters connected therewith or incidental thereto..."175

The subject matters of this Act include domestic violence meaning physical abuse, psychological abuse, sexual abuse or economic abuse against a woman or a child of a family by any other person of that family with who the victim is, or has been, in family relationship. ${ }^{176}$ However, the Act does not provide for the punishment of domestic violence rather it imposes several duties and responsibilities upon Police Officers, Enforcement Officers and Service Providers to the victims of domestic violence. ${ }^{177}$ These duties and responsibilities include helping the victim to get recourse of law, to have medical examination, to get in touch with legal aid service etc. The Domestic Violence Act 2010 empowers the Court to issue a Protection Order after being satisfied that an act of domestic violence has taken place after hearing the applicant and

\footnotetext{
${ }^{171}$ Act No. XXXV of $1980 \mathrm{~s} 5$.

${ }^{172}$ Act No. XXXV of 1980 s 7.

${ }^{173}$ Act No. XXXV of 1980 s 7(b).

174 Act No. XXXV of $1980 \mathrm{~s} 8$.

175 Preamble of the Domestic Violence (Prevention and Protection) Act, 2010, Act No. 58 of 2010.

${ }^{176}$ Act No. 58 of 2010, s 3.

177 Act No. 58 of 2010, Chapter-III ss 4-10.
} 
respondent. ${ }^{178}$ This Protection Order may be in the form of restraining the respondent from committing following acts, namely, ${ }^{179}$

(a) committing any act of domestic violence;

(b) aiding or abetting the commission of any acts of domestic violence;

(c) prohibiting or restraining from entering in any protected person's place of employment, business, or educational institutions or other institutions which the protected person ordinarily visits;

(d) prohibiting or restraining from making any personal, written, telephone, mobile phone, email or any other form of communication with the protected person;

(e) prohibiting from causing violence to the dependants of the victim or any relatives or any person who gives assistance to the victim from domestic violence;

(f) any other act that may be cited in the protection order

Under this law, the Court may restrain the respondent from residing or visiting the shared residence or specified part thereof where the victim resides or may restrain the respondent from dispossessing or in any other manner disturbing the possession of the victim from the shared household. ${ }^{180}$ The victim may get compensation if there is any personal injury or financial loss or trauma or psychological damage or damage to movable or immovable property or if there is any possibility of such damage or loss as a result of domestic violence. ${ }^{181}$ The Court may, at any stage of hearing of the application for a protection order or for any other relief under this Act, may grant order for temporary custody of any child or children of the victim to the victim or to any applicant in favour of the victim and if necessary, the arrangements for any visit to such child or children by the respondent. ${ }^{182}$

The Preamble of the Family Courts Ordinance 1985 defines itself as an Ordinance to provide for the establishment of the Family Courts and for matters connected therewith. ${ }^{183}$ Section 5 of the Family Courts Ordinance 1985 provides that, a Family Court shall have exclusive jurisdiction to entertain, try and dispose of any suit relating to, or arising out of, all or any of the following matters namely, dissolution of marriage, restitution of conjugal rights, dower, maintenance, guardianship and custody of children.

The Family Courts Ordinance 1985 establishes Family Courts under Section 4 of the Ordinance. For the purpose of this law, all Courts of Assistant Judges shall be deemed to be the Family Courts. ${ }^{184}$

\footnotetext{
${ }^{178}$ Act No. 58 of 2010, s 14.

${ }^{179}$ Act No. 58 of 2010, s 14.

${ }^{180}$ Act No. 58 of 2010, s 15.

${ }^{181}$ Act No. 58 of 2010, s 16.

${ }^{182}$ Act No. 58 of 2010, s 17.

183 The Family Courts Ordinance 1985, Ordinance No. XVIII of 1985 preamble.

${ }^{184}$ Ordinance No. XVIII of 1985 , s. 4.
} 
The Family Courts Ordinance 1985 and the Domestic Violence Act 2010 if read together, it becomes clear that, the scope and subject matters related jurisdiction of these two legislations are overlapping in nature. This is particularly, in respect of the matters relating to custody and guardianship of children. The Family Courts Ordinance 1985 confers exclusive jurisdiction to the Family Courts in respect of custody of children. ${ }^{185}$ At the same time, Section 17 of the Domestic Violence Act 2010 empowers the Court to give temporary Order for custody of children in favour of the victim of domestic violence. The Family Courts Ordinance 1985 and the Domestic Violence Act 2010 should be consistent in this respect.

\section{(b) Inconsistency in the definition of 'Dowry':}

Section 2 (b) of the Dowry Prohibition Act 1980 defines 'Dowry' as any property or valuable security exceeding the value of five hundred taka given or agreed to be given either directly or indirectly by either party of the marriage at the time of marriage or at any time before or after the marriage "as consideration for the marriage" of the said parties excluding dower or mehr in the case of persons to whom the Muslim Personal Law (Shariat) applies. ${ }^{186}$ On the other hand, Section 2 (10) of the Nari-o-Shishu Nirjatan Daman Ain 2000 defines "Dowry" as any money, article or anything of value demanded, paid or agreed to be paid by either party of the marriage at the time of marriage or before or after the marriage as a "condition of the continuance of marriage" (বিবাহ স্থির থাকার শর্তে)". ${ }^{187}$ The two concerned legislations therefore put two different qualifications using different terminologies for any payment, demand or agreement to payment to be treated as "Dowry". The Dowry Prohibition Act 1980 requires it to be given or agreed to be given "as consideration for the marriage" and the Nari-o-Shishu Nirjatan Daman Ain 2000 requires it to be demanded, paid or agreed to be paid as a condition of the continuance of marriage (বিবাহ স্থির থাকার শর্তে). Use of two different terminologies in this regard may create confusion. "Condition of the continuance of marriage" has greater connotation than being a "consideration of marriage". Condition of the continuance of marriage may imply that it is a condition to continue the quality of the marital relationship as it was before the condition was being imposed. However, the term "consideration" is generally used as a price for a contract without which a valid contract cannot be executed. ${ }^{188}$ Though for many purposes, Muslim marriage is treated as a civil contract, marriages in other religious communities are sometimes more of rituals than of a civil contract. Therefore, consistency should be brought in the definitions of "Dowry" in the Dowry Prohibition Act 1980 and in the Nari-o-Shishu Nirjatan Daman Ain 2000 using same or equivalent terminologies in this regard.

\section{(c) Inconsistency in the definition of 'Child':}

\footnotetext{
${ }^{185}$ Ordinance No. XVIII of 1985, s 5.

${ }^{186}$ Act No. XXXV of 1980 , s 2(b).

187 Act No. VIII of 2000, s 3(10).

188 The Contract Act 1872 ss 24 and 15.
} 
There is inconsistency in the definition of 'Child' under the Nari-o-Shishu Nirjatan Daman Ain 2000 and the Domestic Violence Act 2010. Section 2(11) of the Nari-o-Shishu Nirjatan Daman Ain 2000 defines 'Child' as any person under the age of 16 (sixteen) years. However, in section 2 (18) of the Domestic Violence Act 2010 defines 'Child' as any person who has not completed 18 years of age. The provisions defining 'Child' in the Nari-o-Shishu Nirjatan Daman Ain 2000 and the Domestic Violence Act 2010 should be made consistent.

\section{(II) Intra-legislative inconsistency}

(a) Inconsistency in the Nari-o-Shishu Nirjatan Daman Ain 2000 on bail granting power

The offences under the Nari-o-Shishu Nirjatan Daman Ain 2000 are cognizable. ${ }^{189}$ Cognizable offences are such offences which can be investigated by any officer-in charge of any Police Station without the Order of a Magistrate or of a Court having jurisdiction to try the offence. ${ }^{190}$ The investigation of any cognizable offence may also be commenced on the basis of an Order of a Magistrate. ${ }^{191}$ Under Section 151 of the Code of Criminal Procedure, 1898, a Police Officer may arrest to prevent the commission of any cognizable offence without warrant or without any Order of a Magistrate. Section 18(1) (ka) and 18(1)(kha) of the Nari-o-Shishu Nirjatan Daman Ain 2000 provide that the investigation of any offence under this law should be completed by 15 working days of the arrest of the accused if he was caught red-handed at the time of the commission of offence or by 60 working days after the Police gets the order of investigation from a Tribunal on the basis of primary information about the commission of offence. This time limit may be extended on reasonable grounds. It is clear from the abovementioned provisions that any person accused of the commission of any offence under the Nari-o-Shishu Nirjatan Daman Ain 2000 can be arrested by Police at any stage of Investigation or even before the commission of the offence on the ground of prevention of the same under section 151 of the Code of Criminal Procedure 1898. As there is a general principle of presumption of innocence till conviction, provisions for granting bail in cognizable offences are expected to be very clear and consistent.

As per the provisions of Section 19 of the Nari-o-Shishu Nirjatan Daman Ain 2000, bail may be granted except in two situations. Firstly, the bail shall not be granted if an opportunity of being heard could not be given to the party lodging the complaint or filing the case. Secondly, bail shall not be granted if the Tribunal is satisfied that there are reasonable grounds indicating possibility of conviction at the end of the trial. However, the Nari-o-Shishu Nirjatan Daman Ain 2000 is silent about the procedure of granting bail during the investigation stage of the proceedings. It is not necessary under the law that the initial proceeding under this legislation is to be initiated at the Nari-o-Shishu Nirjatan Daman Tribunals. The Proceeding may be initiated

\footnotetext{
${ }^{189}$ Act No. VIII of 2000, s 19(1).

190 The Code of Criminal Procedure 1898, s 156.

191 Ibid.
} 
by the Police on the basis of the General Registered Cases (GR) or by the Magistrate on the basis of the Complaint Registered (CR) Cases as the offences are cognizable in nature. Under the existing provisions of the Nari-o Shishu Nirjatan Daman Ain 2000, the Tribunals can only hear bail matters in the GR cases after the stage of submission of Police Reports/Investigation Reports and not before. Before submission of the Police Report/Investigation Report, the bail granting power remains within the jurisdiction of the Magistrates. However, the Nari-o-Shishu Nirjatan Daman Ain 2000 does not incorporate any enabling provisions conferring bail granting power to the Magistrates. Though, the general provisions of the Code of Criminal Procedure ${ }^{192}$ confer such bail granting power to the Magistrates in this respect, the silence in the Nari-o-Shishu Nirjatan Daman Ain 2000 may create confusion. In a recent notification from the Ministry of Law, Justice and Parliamentary Affairs of the Government of People's Republic of Bangladesh it is provided that, bail granting power till submission of the investigation report/Police Report should be exercised by the Magistrates not by the Tribunals. ${ }^{193}$ Clarification by notification in this regard is an insufficient step and a proper legislative amendment is required to bring consistency among these legal provisions. ${ }^{194}$

During our field work at Dhaka, Comilla and Pabna Courts, most of the Judges of Nari-o-Shishu Nirjatan Daman Tribunals and Magistrates who deal with the VAW cases till the stage of submission of Investigation Report/Police Report have opined that, this confusion should be removed by a clear provision of law. Most of the participants of qualitative interview has suggested that, the whole Proceeding should be brought under the same umbrella and the Nari-oShishu Nirjatan Daman Tribunals should be given power to grant bail at any stage of the Proceeding be it a GR Case or a CR Case. They have also suggested that, though CrPC empowers the Magistrates to grant bail, they do not prefer to grant bail in the VAW cases because of the silence of the Nari-o-Shishu Nirjatan Daman Ain 2000 in this regard. Since it ultimately affects ensuring justice, this issue is recommended to be addressed.

\section{(III) Inconsistency with other general legislations as identified in the Supreme Court's judgments}

It is observed by the Supreme Court of Bangladesh that the Nari-o-Shishu Nirjatan Daman Tribunals constituted under the Nari-o-Shishu Nirjatan Daman Ain 2000 often go beyond their subject matter jurisdiction. ${ }^{195}$ The Supreme Court has also observed that the Nari-o-Shishu Nirjatan Daman Tribunals often fails to realize that they are Special Courts and cannot try any offence relating to violence against women which should actually be tried by the Sessions Courts

192 The Code of Criminal Procedure 1898, s 496.

193 Notification No. 660-bichar-3/2 m-14/88 (ongsho) dated 11/12/2014 signed by Md. Shaheen Uddin, Senior Assistant Secretary issued by the Division of Law and Justice, Ministry of Law, Justice and Parliamentary Affairs, People's Republic of Bangladesh.

194The Law Commission of Bangladesh : The recommendations on clarification of jurisdiction of Courts to grant bail till submission of Police Report in the cases filed under Nari-O Shishu Nirjatan Daman Ain 2000 (2012) <http://www.lc.gov.bd/reports/115-Women\%20and\%20Child\%20Ain,\%202000.pdf>.

195The State vs. Bahar Mia (2004) 56 DLR (HCD) 454. 
framing charge under the Penal Code of $1860 .{ }^{196}$ This observation by the Supreme Court of Bangladesh indicates that there may be inconsistency between the provisions of the Penal Code 1860 and the Nari-o-Shishu Nirjatan Daman Ain 2000 which ultimately results into misconstruction of law by the Nari-o-Shishu Nirjatan Daman Tribunals at the trial stage of the VAW Cases.

This research has screened all the reported ${ }^{197}$ VAW cases in the years of 2000 to 2013 . Through this screening, this work could identify some provisions of the Nari-o-Shishu Nirjatan Daman Ain 2000 and Penal Code 1860 on which the Trial Courts (Nari-o-Shishu Tribunals) have been often found to commit misconstruction of law relating to their jurisdiction. This issue is taken up for consideration because, if the VAW legislations are consistent with other related general legislations, there should be no case of such misconstruction of law.

The Supreme Court has observed that the offence of death for dowry cannot be tried under the Nari-o-Shishu Nirjatan Daman Ain 2000 if the demand of dowry could not be proved. ${ }^{198}$ In that situation, it should rather be tried as the offence of murder under Section 302 of the Penal Code 1860. ${ }^{199}$ In the case of Mozam vs. State, 59 DLR (2007), 276, the High Court Division of the Supreme Court of Bangladesh found the Nari-o-Shishu Nirjatan Daman Tribunal of Jessore to pass conviction u/s 4(c)/ 9 of the Cruelty to Woman Ordinance 1983 though the Tribunal had no jurisdiction to convict under the Cruelty to Woman Ordinance 1983. In the case of Anwar Hossain vs State, 61 DLR 2009, pg-671, the High Court Division of the Supreme Court of Bangladesh observed that between Section 367 of the Penal Code 1860 (for the offence of abduction in general) and Section 9 (abduction of women) of the Nari-o-Shishu Nirjatan Bishesh Bidhan Ain $1995^{200}$, the provision in the Nari-o-Shishu Nirjatan Act shall prevail as special law prevails over general law. In this case the conviction could not sustain as the requirement of retaining, taking or using any woman for certain purpose to constitute the offence of abduction under the Nari-o-Shishu Act could not be satisfied. The accused person was arrested on the spot by public at the time of forcing the woman for the purpose of abduction. However, in the definition of abduction given by Section 367 of the Penal Code, these requirements of retaining, taking or using any person for certain purpose are absent. Under the Penal Code, it is enough if the act is committed to put any person in danger. Therefore, Section 367 of the Penal Code has more extensive scope than the provisions relating to abduction in the special Nari-o-Shishu Act. Consistency in this respect may be brought.

Again, the Nari-o-Shishu Nirjatan Daman Tribunals have been found committing misconstruction of the procedural provisions of the Nari-o-Shishu Nirjatan Daman Ain 2000. In one instance, the Tribunals could not harmoniously construct Section 27(1) of the Nari-o-Shishu

196 Ibid.

197 Reported in the Dhaka Law Reports (DLR)

${ }_{199}^{198}$ State vs. Bahar Mia (2004) 56 DLR (HCD) 454; Abul Kalam Azad vs. State (2006) 58 DLR (AD) 26.

${ }^{199}$ Ibid.

${ }^{200}$ The equivalent Section now is Section 5 of the Nari-O Shishu Nirjatan Daman Ain 2000. 
Nirjatan Daman Ain 2000 and Section 173 of the Code of Criminal Procedure $1898 .^{201}$ The Nari$o$-Shishu Tribunal was found taking direct cognizance of a VAW offence without referring the matter to the Court of Magistrate for the purpose of inquiry. ${ }^{202}$ The Supreme Court has observed that Police Report under Section 173 of the Code of Criminal Procedure 1898 must be submitted before the Nari-o-Shishu Nirjatan Daman Tribunals take cognizance of the case. ${ }^{203}$ In another instance, the Nari-o-Shishu Nirjatan Daman Tribunal has been found to transfer a case to the Druto Bichar Tribunal before taking cognizance to which the Nari-o-Shishu Nirjatan Tribunal was not authorized. ${ }^{204}$

These instances indicate that procedural provisions of the Nari-o-Shishu Nirjatan Daman Ain 2000 are not clear and consistent enough with other general legislations.

Lastly, in a recent judgment in the case of Shukkur Ali vs. State ${ }^{205}$ the Appellate Division of Bangladesh Supreme Court has declared the mandatory provision of death sentence for the crime of murder after rape as provided in sections 6(2), 6(3) and 6(4) of the Nari-o-Shishu Nirjatan Daman Bishesh Bidhan Ain 1995 as unconstitutional. ${ }^{206}$ The Appellate Division of Bangladesh Supreme Court has also recommended the Government to amend the mandatory death sentence provisions for causing death for dowry. The Nari-o-Shishu Nirjatan Daman Ain 2000 has already altered this stance by not providing for mandatory death sentence for murder after rape. However, in section 34(2) of the Nari-o-Shishu Nirjatan Daman Ain 2000, it is provided that the cases filed for this crime before the Nari-o-Shishu Nirjatan Daman Ain 2000 would continue to be tried under the Nari-o-Shishu Nirjatan Daman Bishesh Bidhan Ain 1995. The Appellate Division of Bangladesh Supreme Court has therefore declared section 34(2) of the Nari-o-Shishu Nirjatan Daman Ain 2000 to be unconstitutional as well. Now, there is a legal vacuum at the moment as to under which legal provision the cases filed for murder after rape before coming into force of the Act of 2000 will be tried. Article 35 of the Constitution of Bangladesh provides that no person shall be convicted of any offence except for the violation of a law in force at the time of the commission of the act charged as an offence, nor shall be subjected to a penalty greater than or different from, that which might have been inflicted under the law in force at the time of the commission of the offence. Therefore, this inconsistency of law should be subjected to immediate legislative amendments as may be necessary to address this problem.

201 Amin Uddin (Md) vs. State, (2006) 58 DLR.

202 Ibid.

203 Ibid.

${ }^{204}$ Shaheen (Md) vs. State (2007) 59 DLR, 23.

205 The Judgment is passed by the Appellate Division of Bangladesh Supreme Court on 5 May 2015. The certified copy of the Judgment is not yet available. The Judgment is not yet reported in any Law Report.

${ }^{206}$ The Daily Prothom Alo, 6 May 2015 <www.prothom-alo.com>. 


\section{CHAPTER 7 \\ CONCLUSION AND RECOMMENDATION}

Being the concluding part, this chapter summarizes some of the recommendations based on the findings of the present research. The data analysis and the findings were intended to be objective so that it can be a helpful guide for the justice sector agencies. Therefore, the recommendations summarized in this chapter are non-exhaustive in nature.

7.1. From the analysis of the quantitative and qualitative data collected from the justice sector agencies of the Nari-o-Sishu Nirjatnan Daman Tribunals of Dhaka, Comilla and Pabna it is now evident that conviction rate in the VAW cases under the Nari-o-Sishu Nirjatan Daman Ain 2000 is extremely low. The eight hypotheses that imply the reasons for this low conviction rate also have been appropriately confirmed by the data analysis. In addition to those hypotheses, the judgments of the Supreme Court, however, significantly observe some important reasons for low conviction rate including the nonapplication of judicial mind by the trial court. Over the years, this is exhibited thorough impropriety, legal infirmity, and lack of sound reasoning in the trial court's decision, excessive use of jurisdiction by the trail court, framing of wrong charge by the Tribunal, and inappropriate procedure of trial. This research, therefore, concludes by contending that while all the reasons as mentioned in the hypothesis are the underlying reasons, nonapplication of judicial mind by the trial court undeniably adds an important factor that is responsible for the low conviction rate in the VAW cases. Based on the suggestions of the justice sector agencies, and analysis of relevant judicial decisions and literatures, this research recommends as follows-

a) The key justice sector agencies who are entrusted with the duty to collect and present the evidence before the court, e.g., police officers, medical officers, and public prosecutors should be more concerned about the rights of the victims and their corresponding duties.

b) More senior, experienced and knowledgeable persons should be appointed as the Public Prosecutors of the VAW Tribunals.

c) The public prosecutors should not be negligent and should be more cooperative to the victims.

d) There should be strict legal accountability mechanism for the public prosecutors.

e) To prevent the abuse of justice, harshness of the Nari-o-Sishu Nirjatan Daman Ain 2000 is suggested to be mitigated by the justice sector agencies. 
f) To minimize the rate of filing of false cases, the trial court should be more cautious in taking cognizance of an offence and should take recourse to section 17 of the Nari-oSishu Nirjatan Daman Ain 2000 to punish anyone who files a false case.

g) It is found that although there is no provision for out of court settlement in the 2000 Act; judges allow it as the least worst option when in a case the victim herself is unwilling to continue the case. In this context, strict application of the Act can improve the current situation.

h) A coordinated effort among all the justice sector agencies, establishment of more Nari-o-Shish $u$ tribunals, and appointment of judge at the tribunal where there is no judge can reduce case backlog.

i) In addition to the suggestions made by the justice sector agencies during the field visits of this research to curb the low rate of conviction, some of the judgments of the Supreme Court demonstrate that judges of the tribunal are expected to apply their judicial mind while dealing with the VAW cases under the Nari-o-Sishu Nirjatan Daman Ain 2000.

j) The provisions of punishment in the Nari-o-Shishu Nirjatan Daman Ain 2000 should be revised. Harsher punishment cannot mitigate the offence rather may result into a low rate of conviction in the VAW cases. Punishment for the VAW offences should, therefore, be proportionate to the gravity of the offence.

k) The Nari-o-Shishu Nirjatan Daman Ain 2000 should provide for a wider space of discretion of the Judges for sentencing the offender.

1) Medical evidence collection process for the VAW cases should be more women friendly and appointment of lady doctors for this purpose is strongly recommended.

m) Record keeping of the VAW cases should be smarter. Recourse of modern technology may be taken. A paperless judiciary is highly recommended in this regard.

n) Creating awareness about legal aid should be emphasized.

It should however, be made clear that by identifying the level and reasons behind low conviction rate in the VAW cases, this research in any way does not advocate for the 
conviction rate to be high, rather, it expects for a proper administration of justice that aims to uphold the rights of the poor and marginalized victims of the violence as envisioned in the Act of 2000.

7.2. Through quantitative and qualitative data analysis, a number of inconsistencies are identified in this research in the four specific VAW legislations namely, the Nari-oShishu Nirjatan Daman Ain 2000, the Dowry Prohibition Act 1980, the Domestic Violence Act 2010 and the Family Courts Ordinance 1985. This research could not find any provision in these legislations to be directly contradictory to any other provision. However, a number of provisions are identified which require more clarification or little amendments so that they can operate harmoniously without creating confusions. There is overlapping in the subject matters dealt by these four specific VAW legislations. Dowry related offences are partly dealt in the Nari-o-Shishu Nirjatan Daman Ain 2000 and partly dealt in the Dowry Prohibition Act 1980. Bail granting power in the GR cases till the completion of investigation under the Nari-o-Shishu Nirjatan Daman Ain 2000 should be expressly conferred by this Act. It is observed by the Supreme Court of Bangladesh in a number of cases that the special Tribunals constituted under the Nari-oShishu Nirjatan Daman Ain 2000 often goes beyond their jurisdiction in trying the VAW cases. The Tribunals have been found committing misconstruction of law both procedural and substantive at several instances. Following are the recommendations to find out an effective solution to this problem-

(a) All the offences related to dowry should be dealt comprehensively by any single legislation either by the Nari-o-Shishu Nirjatan Daman Ain 2000 or by the Dowry Prohibition Act 1980.

(b) The definition of "Dowry" given in the Nari-o-Shishu Nirjatan Daman Ain 2000 and in the Dowry Prohibition Act 1980 should be made uniform. Currently, different terminologies are used in these two legislations to define "Dowry".

(c) The definition of "Child" given by the Nari-o-Shishu Nirjatan Daman Ain 2000 and the Domestic Violence Act 2010 should be made consistent. At present, these two legislations prescribe two different categories of age limits to define "Child".

(d) Bail related provisions in the Nari-o-Shishu Nirjatan Daman Ain 2000 should be made more clarified. The Nari-O-Shishu Nirjatan Daman Tribunals should be conferred with the bail granting power from the very beginning of the proceeding be it a Complaint Registered (CR) case or a General Registered (GR) case. 
(e) Procedural provisions as to from which stage of the case, the Nari-o-Shishu Nirjatan Daman Tribunal takes cognizance of the case should be more clear and specific.

(f) The scope of applicability of the Code of Criminal Procedure 1898 to the Nari-oShishu Nirjatan Daman Ain 2000 should be clearly and specifically mentioned in the law.

(g) All the offences relating to the violence against women should be tried by one single Court or Tribunal.

(h) In several cases, it is found by the Supreme Court of Bangladesh that the Nari-oShishu Nirjatan Daman Tribunals often try the VAW related offences under inappropriate sections of law. A strong inference, therefore, can be drawn that the definitions of offences under the Nari-o-Shishu Nirjatan Daman Ain 2000 are not clear and specific. This problem may be addressed by legislative amendments. For example, the definition of "Abduction" may be widened like that of the definition given in the Penal Code 1860.

(i) In a recent judgment given by the Appellate Division of Bangladesh Supreme Court in Shukkur Ali vs. State (Decision given on 5 May 2015, not reported yet) it is recommended that Section 11 of the Nari-o-Shishu Nirjatan Daman Ain 2000 dealing with "Dowry" should be reconsidered by the Government. The present research also supports this stance and recommends necessary actions.

(j) The provisions relating to "Custody of Child" in the Family Courts Ordinance 1985 and in the Domestic Violence Act 2010 should be made more clarified and specific as to which law will apply in which situation to avoid further confusion.

(k) In Shukkur Ali vs. State, the Appellate Division of Bangladesh Supreme Court has annulled Section 34(2) of the Nari-o-Shishu Nirjatan Daman Ain 2000 finding it to be inconsistent with the Constitution of Bangladesh. Section 34 (2) of the Act of 2000 provided for the continuation of trial for murder after rape before coming into force of the Act of 2000 to be tried under the provisions of the Nari-o-Shishu Nirjatan Daman Bishesh Bidhan Ain 1995. The Act of 1995 provides for mandatory death sentence for the offence of murder after rape which is found unconstitutional by the Court. These legal issues are required be addressed by necessary legislative amendments to mitigate harshness of punishment. 
The recommendations given above being non-exhaustive, present research suggests that the data collected and presented in the work as well as the legal analysis made may be a basis of work in the future. 


\section{BIBLIOGRAPHY}

\section{LIST OF BOOKS AND ARTICLES}

1. Adams, Adrienne E, Sullivan, Cris M, Bybee, Deborah and Greeson, Megan R, 'Development of the Scale of Economic Abuse' (2008) Violence Against Women 563

2. Agnes, Flavia, 'Violence against Women: Review of Recent Enactments' in Swapna Mukhopadhay (eds), In the Name of Justice: Women and Law in Society (Delhi, 1998) 80

3. Aliaga, Mertha and Brenda Gunderson, 'A Definition of Qualitative Method' in Mark Balnaves and Peter Caputi Introduction to Quantitative Research Method (Sage Publications Limited, 2001)

4. Ameen, Nusrat, 'Law and the State's Response towards Violence against Women' (2000) 4 Bangladesh Journal of Law 27

5. American Prosecutors Research Institute, 'Do Lower Conviction Rates Mean Prosecutors' Offices are Performing Poorly? (2007) 1

6. APWLD, My Rights, Who Control?, Asia-Pacific women's Issues, Law and the Development Process, Asia Pacific Forum on Women, Law and Development (1990)

7. Baron, Robert A, Human Aggression (Plenum Press, New York, 1984)

8. Barry, Kathleen, Female Sexual Slavery (New York University Press, 1984) in Muhammd, Rafi, Banu, Dilruba, Alim, Md. Abdul and Akter, Shaheen, An Assessment of Male Attitude Towards Violence Against Women (BRAC, 2003)

9. Beauchamp, Tom L, Distributional Justice and the Difference Principle in John Rawl's Theory of Social Justice: An Introduction (Ohio University Press, Athens, 1982)

10. Bergen, Raquel K, Marital Rape: New Research and Directions (VAW Net, 2006)

11. Brownmiller, Susan, Against Our Will: Women, Men and Rape (Penguin, Middlesex, 1975)

12. Chowdhury, Elora H, 'Negotiating State and NGO Politics in Bangladesh: Women Mobilize against Acid Violence' (2007) 13 Violence against Women 857

13. Chowdhury, Jamila A, 'Women's Access to Fair Justice in Bangladesh: Is Family Mediation a Virtue or Vice' in Chowdhury, Jamila A, 'Legal Aid and Women's access to Justice in Bangladesh' (2012) 1 International Research Journal of Social Sciences 8

14. Cresswell, John W, 'Research Design: Qualitative, Quantitative, and Mixed Methods Approaches' (Sage Publications, 2009)

15. Ellsberg, Mary and Lori Heise, Researching Violence against Women: A Practical Guide for Researchers and Activists (Washington DC, United States: World Health Organization, PATH, 2005)

16. Farouk, Sharmeen A, 'Violence against women: A statistical overview, challenges and gaps in data collection and methodology and approaches for overcoming them' (2005) Expert Group Meeting, UN Division for the Advancement of Women in collaboration with Economic Commission of Europe and World Health Organization, Switzerland 11-14

17. Felson, Richard B and Paul-Philippe Pare, 'The Reporting of Domestic Violence and Sexual Assault by Non-strangers to the Police' (2005) 67 Journal of Marriage and Family 597

18. Firebaugh, Glenn, Seven Rules for Social Research (Princeton University Press, 2008) 
19. Gelles, Richard J and Donileen R Loseke (eds), Current Controversies on Family Violence (Sage, Newbury Park, 1993)

20. Gottfried, Heidi, 'Beyond Patriarchy? Theorizing Gender and Class' (1998) 32 Sociology 451

21. Hossain, Kazi T and Muhammad Hasan Imam (eds), Males' Perception on Violence against Women in Bangladesh (British Council, Dhaka, 2001)

22. Jahan, Roushan, 'Family Violence and Bangladeshi Women: Some observations' in Roushan Jahan, Latifa Akhanda (eds), Women for Women (Dhaka, 2003)

23. Jahan, Roushan, 'Hidden Danger: Women and Family Violence in Bangladesh', Women for Women (Dhaka, 1994) 165.

24. Johnson, Holly, Natalia Ollus, Sami Nevala, Violence against Women: An International Perspective (Springer, 2008)

25. Kelly, Liz, Surviving Sexual Violence (Polity Press, 1987)

26. Khan, M E and Aeron, Aditi, 'Prevalence, Nature and Determinants of Violence against Women in Bangladesh' (2006) 52 The Journal of Family Welfare 33

27. Krug, Etienne $\mathrm{G}$ et al, World Report on Violence and Health (Geneva: World Health, 2002)

28. Kumar, Ranjit, Research Methodology: A Step-By-Step Guide for Beginners (Pearson Education Australia, 2005)

29. McMillan, Lesley, Feminists Organizing against Gendered Violence (Palgrave, 2007)

30. Mustrad, David, 'Reexamining Criminal Behaviour: The Importance of Omitted Variable bias' (2003) 85 The Review of Economics and Statistics 205

31. Nigam, Shalu, 'Silent Enemy in the Home' (2002) 49 Social Welfare 8 in Sharma, BR. and Gupte, M., 'Gender Based Violence in India: A Never Ending Phenomenon' (2004) 6 Journal of International Women's Studies 114

32. Radford, Jill, Friedberg, Melissa and Harne, Lynne (eds), Women, Violence and Strategies for Action: Feminist Research Policy and Practice (Open University Press, 2000)

33. Reilly, Niamh, Women's Human Rights-Seeking Gender Justice in a Globalizing Age (Polity Press, 2009)

34. Solotaroff, Jennifer L, Prabhande, Rohini and Lopez-Acevedo, Gladys, Violence against Women and Girls: Lessons from South Asia (World Bank, 2014)

35. The Sieve Effect: South Africa's Conviction Rates in Perspective, (2003) 5 SR Crime Quarterly (22-02-2015) <http://www.issafrica.org/uploads/3SA.PDF>

36. The South Asia Regional Initiative and Equality Support Programme, Landmark Judgments on Violence against Women and Children in South Asia 8 (13-01-2015) <http://www.childtrafficking.com/Docs/judge_woman_childvio_0607.pdf>

37. Tania, Sharmin, 'Special Criminal Legislation for Violence against Women and Children-A Critical Examination' [2007] Bangladesh Journal of Law 199

38. Zaman, Habiba, 'Violence against Women in Bangladesh: Issues and Response' (1999) 22 Women's Studies International Forum 37 


\section{LIST OF REPORTS}

1. Law Commission, Bangladesh, Analysis of Muslim Family Law and some recommendations (2202-2015) $<$ http://www.lc.gov.bd/reports/120-Final\%20Report\%20of\%20Muslim\%20Law05\%20sir\%20.pdf>

2. Law Cmmission, Bangladesh, Recommendations on clarification of jurisdiction of Courts to grant bail till submission of Police Report in the cases filed under Nari-O Shishu Nirjatan Daman Ain 2000 (22-02-2015) <http://www.lc.gov.bd/reports/115-Women\%20and\%20Child\%20Ain,\%202000.pdf>

3. Law Commission, Bangladesh, Recommendations to amend some provisions of Nari-O Shishu Nirjatan Domon Ain 2000 (22-02-2015) <http://www.lc.gov.bd/reports.htm>

4. Malik, Shahdeen, 'Looking at Law and its Implementation' [2004] Unpublished Report for Naripokkho

5. Moran, Greg et al, 'Perceptions, Attitudes and Understanding: A Baseline Survey on Human Rights in Bangladesh' [2011] National Human Rights Commission of Bangladesh 40

6. Naomi, Sharin Shajahan, 'The Legal Challenges on the Way to Judicial Remedy in Rape Cases: The Role of Human Rights and Legal services Programme of BRAC' [2009] BRAC Research Report

7. National Human Rights Commission of Bangladesh, Perceptions, Attitudes and Understanding: A Baseline Survey on Human Rights in Bangladesh (Final Report, October 2011)

8. The South African Law Commission, Conviction rates and other outcomes of crimes reported in eight South African Police Areas (Research Paper 8, Project 82) (22-02-2015) <http://www.unafei.or.jp/english/pdf/RS_No53/No53_31RC_Group3.pdf>

9. Report of the sub regional expert group meeting on eliminating violence against women, Violence against women in South Asia (2000) Report No: ST/ESCAP/2099 (New York: United Nations, 2000)

10. UNDP, Human Security in Bangladesh (September 2002) 107-108

\section{LIST OF CASES}

1. Abdul Aziz v Sonia Pervin Liza (2006) 58 DLR 583

2. Abdul Haque Dakua v State (2012) 17 BLC (HCD) 257

3. Abdul Gaffar v State (2011) 31 BLD (HCD) 564

4. Abdul Motaleb Howlader v State (2001) 21 BLD (AD) 27

5. Abul Kalam Azad v State (2006) 58 DLR (AD) 26

6. Afshar Ali v State (2009) 14 MLR (HCD) 369

7. Ahsan Ullah v Bangladesh (2000) 52 DLR 168

8. Alamgir v Habea Begum (2000) 52 DLR 157

9. Amin Uddin (Md) v State (2006) 58 DLR 294

10. Anwar Hossain Chowdhury v Bangladesh (1989) 41 DLR (AD) 165 (' $8^{\text {th }}$ Amendment Case')

11. Anwar Hossain v State (2009) 61 DLR 671

12. Anwara Begum v State (2011) 19 BLT (HCD) 401 
13. Ashraful Alam v State (2005) 57 DLR 718

14. Atiqur Rahman v Ainunnahar (2000) 52 DLR 453

15. Babu Miah v State (2013) 18 BLC (HCD) 598

16. Debobrota Baiddya v State (2006) 26 BLD (HCD) 15

17. Dilruba Aktar v AHM Mohsin (2003) 55 DLR 568

18. Fazlu v State (2008) 28 BLD (HCD) 659

19. Fazlur Rahman v Bangladesh (2001) 53 DLR 237

20. Firojul Islam v Zahanara Akter (2000) 52 DLR 107

21. Ganesh Chandra Das v Arati Acharjya (2002) 54 DLR 348

22. Gour Chandra Pal v State (2007) 27 BLD (HCD) 173

23. Hasibur Rahman v Shakila Begum (2001) 53 DLR 152

24. Hossain Md. Rajib v State (2011) 19 BLT (HCD) 388

25. Hossain Md. Rajib v State (2011) 31 BLD (HCD) 368

26. Jashimuddin v Dali Begum (2004) 56 DLR 358

27. Jharna Begum v State (2012) 32 BLD (HCD) 542

28. Kamal Hossain v State (2009) 61 DLR 505

29. Kazi Nurun Nabi Parag v State (2010) 15 MLR (HCD) 84

30. Kazi Nurun Nabi Parag v State (2011) 19 BLT (HCD) 205

31. Khandaker Abdul Hannan v Sayara Begum (2004) 56 DLR 141

32. Kowsar Chowdhury v Latifa Sultana (2002) 54 DLR 175

33. M Moinul Khan v State (2006) 58 DLR 253

34. Major (retd) Nurullah v State (2012) 17 BLC (HCD) 831

35. Md. Abdul Hashem v State (2011) 31 BLD (HCD) 427

36. Md. Abdur Rouf Moral v State (2008) 28 BLD (HCD) 357

37. Md. Ehsanullah v State (2012) 32 BLD (HCD) 447

38. Md. Mohor Ali v State (2012) 32 BLD (HCD) 370

39. Md. Morshed Alam v State (2001) 21 BLD (HCD) 350

40. Md. Naimuddin v State (2007) 27 BLD (HCD) 232

41. Md. Rashed Ahkond v State (2013) 21 BLT (HCD) 443

42. Mehedi Hasan $v$ State (2012) 17 BLC (HCD) 436

43. Mehedi Hasan v State (2012) 32 BLD (HCD) 578

44. Monir Hossain v State (2007) 27 BLD (HCD) 263

45. Monir Hossain v State (2007) 59 DLR 416

46. Mozam v State (2007) 59 DLR 276

47. Mrs. Fatema Begum v State (2007) 27 BLD (HCD) 502

48. Nakib Ashraf Ali v State (2009) 14 MLR (HCD) 286

49. Nirmal Chandra Shaha v State (2010) 30 BLD (HCD) 584

50. Rajib Kumar Hasan v State (2001) 21 BLD (AD) 46

51. Rehana Begum v State (2011) 16 MLR (HCD) 75

52. Rehana Begum v State (2011) 63 DLR 548

53. Roni Ahmed Liton v State (2009) 14 MLR (HCD) 412

54. Roni Ahmed Liton v State (2009) 29 BLD (HCD) 386

55. Safazuddin v State (2007) 27 BLD (HCD) 321 
56. Saleha Begum v Dilruba Begum (2001) 53 DLR (2001) 346

57. Sarder Lutfur Rahman v State (2011) 19 BLT (HCD) 280

58. Shafiqul Huq v Mina Begum (2002) 54 DLR 481

59. Shaheen $(M d)$ v State (2007) 59 DLR 23

60. Shahin v State (2007) 27 BLD (HCD) 448

61. Sirajul Islam v State (2012) 17 BLC (HCD) 740

62. Sree Pintoo Pal v State (2010) 30 BLD (HCD) 220

63. State v Alam (2011) 31 BLD (HCD) 226

64. State v Anjali Debi (2009) 29 BLD (HCD) 445

65. State v Anjali Debi (2009) 61 DLR 738

66. State v Farid (2012) 17 MLR (HCD) 457

67. State v Hasibul Hasan (2012) 64 DLR 291

68. State v M A Mannan [2013] NOSNDTC 199 (6 April 2015)

69. State v M A Rashid [2010] NOSNDTC 394 (7 April 2015)

70. State v Manik Miah [2012] NOSNDTC 460 (2 April 2015)

71. State v Md. Akinur Rahman (2011) 19 BLT (HCD) 406

72. State v Md. Atiqur Rahman (2012) 17 BLC (HCD) 630

73. State v Md. Halim Howlader (2006) 26 BLD (HCD) 438

74. State v Md. Moinul Haque (2001) 21 BLD (AD) 465

75. State v Md. Rafique (2009) 61 DLR 158

76. State v Md. Roushan Mondal (2006) 26 BLD (HCD) 549

77. State v Mojammel [2011] NOSNDTC 84 (6 April 2015)

78. State v Momen Miah [2013] NOSNDTC 620 (5 April 2015)

79. State v Noor Islam (2011) 16 MLR (HCD) 141

80. State v Noor Islam (2011) 31 BLD (HCD) 285

81. State v Sadequl Islam (2011) 63 DLR (AD) 134

82. State v Sobir Hossain [2010] NOSNDTC 124 (8 February 2015)

83. Sudhir Kumar Das alias Khudi v State (2008) 60 DLR 261

84. Suparna Rani Pal alias Jannatul Ferdous v State (2011) 19 BLT (HCD) 470

85. Tota Howlader v State (2011) 16 MLR (HCD) 355

86. Uzzal alias Elias Hossain v State (2007) 59 DLR 505

87. Zitu Ahsan v State (2007) 59 DLR 528

\section{LIST OF LEGISLATIONS}

1. The Constitution of the People's Republic of Bangladesh

2. The Declaration on the Elimination of Violence against Women, 1998

3. The Domestic Violence (Protection and Prevention) Act, 2010

4. The Dowry Prohibition Act, 1980

5. The Family Courts Ordinance, 1985

6. The Muslim Family Law Ordinance, 1961

7. The Nari-o-Shishu Nirjantan Daman Ain, 2000 (as amended in 2003)

8. The National Women Development Policy, 2011 